\title{
WestVirginiaUniversity
}

THE RESEARCH REPOSITORY @ WVU

Graduate Theses, Dissertations, and Problem Reports

2014

\section{Evaluation of asphalt pavements construction practice in West Virginia}

Masoud Seyed Mohammad Ghavami

West Virginia University

Follow this and additional works at: https://researchrepository.wvu.edu/etd

\section{Recommended Citation}

Seyed Mohammad Ghavami, Masoud, "Evaluation of asphalt pavements construction practice in West Virginia" (2014). Graduate Theses, Dissertations, and Problem Reports. 400.

https://researchrepository.wvu.edu/etd/400

This Thesis is protected by copyright and/or related rights. It has been brought to you by the The Research Repository @ WVU with permission from the rights-holder(s). You are free to use this Thesis in any way that is permitted by the copyright and related rights legislation that applies to your use. For other uses you must obtain permission from the rights-holder(s) directly, unless additional rights are indicated by a Creative Commons license in the record and/ or on the work itself. This Thesis has been accepted for inclusion in WVU Graduate Theses, Dissertations, and Problem Reports collection by an authorized administrator of The Research Repository @ WVU. For more information, please contact researchrepository@mail.wvu.edu. 


\title{
EVALUATION OF ASPHALT PAVEMENTS CONSTRUCTION PRACTICE IN WEST VIRGINIA
}

\author{
MASOUD SEYED MOHAMMAD GHAVAMI
}

Thesis submitted

to the Benjamin M. Statler College of Engineering and Mineral Resources at West Virginia University

\author{
in partial fulfillment of the requirements for the degree of \\ Master of Science in \\ Civil Engineering
}

\author{
Dr. John P. Zaniewski \\ Dr. John Quaranta \\ Dr. Fei Dai
}

Department of Civil and Environmental Engineering

Morgantown, West Virginia

2014

Keywords: Asphalt, Construction, Pavement, Monitoring

Copyright 2014 MASOUD GHAVAMI 


\section{ABSTRACT \\ EVALUATION OF ASPHALT PAVEMENTS CONSTRUCTION PRACTICE IN WEST VIRGINIA}

\section{MASOUD SEYED MOHAMMAD GHAVAMI}

Construction practice is a key factor in building high quality pavement. Unfortunately failure and distresses frequently develop shortly after construction. These distresses may be due to the contractors failing to follow the guidelines and specifications. Monitoring pavement construction provides information for evaluating contractors' practices relative to the best practices as documented in various training courses. Accordingly, the West Virginia Department of Highways (WVDOH) decided to review construction practices. The WVDOH hired 4 co-ops during summer 2012 and 2 co-ops during summer 2013 to document asphalt pavement construction projects. The co-ops were assigned to observe and record pavement construction practices. Observations were documented on forms with supporting photographs and video records. West Virginia University was contracted to train and monitor the co-ops and gather and analyze the construction monitoring information. All the observations data were put into and analyzed using a Microsoft Access database. The results for summer 2012 shows that plant operations comply with best management practices in most areas. However, the observations did indicate several opportunities for improvement in the hauling, placement and compaction of the asphalt concrete. Observations from summer 2013 showed plant operations remained "good", the performance of hauling, surface preparation, placement and compaction of the asphalt concrete were better than observed in 2012 . 


\section{TABLE OF CONTENTS}

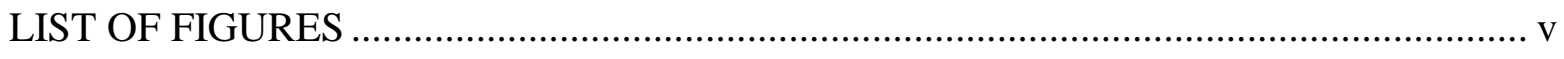

LIST OF TABLES .............................................................................................. viii

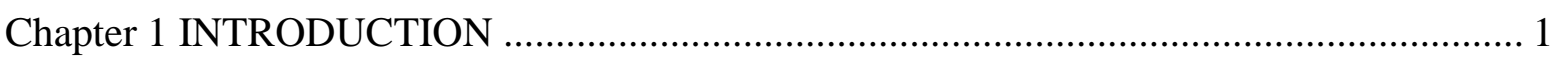

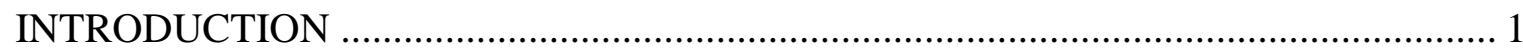

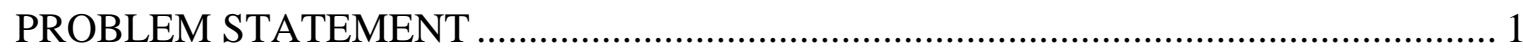

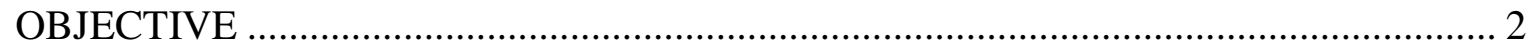

SCOPE AND LIMITATIONS ........................................................................... 2

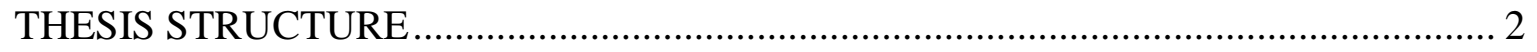

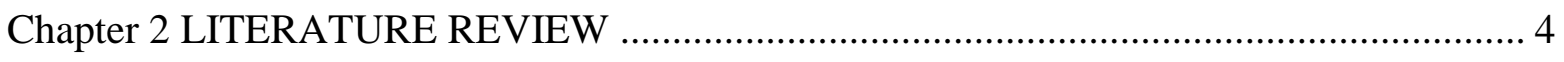

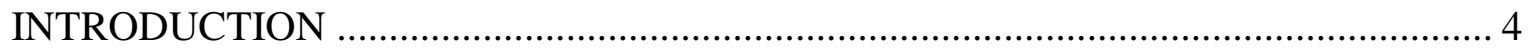

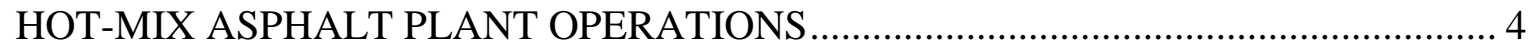

AGGREGATE STOCKPILES ...................................................................... 4

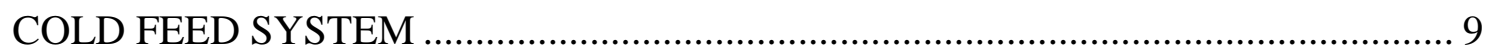

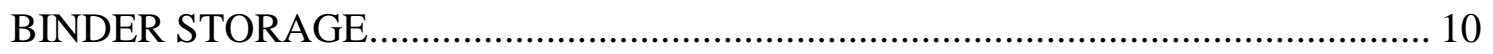

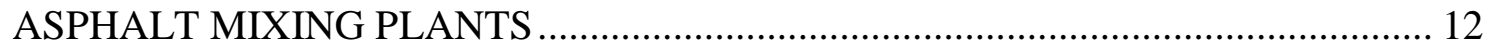

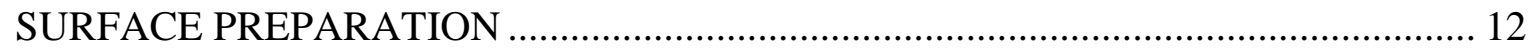

REPAIR OF THE PAVEMENT STRUCTURE AND DRAINAGE ISSUES .............. 12

TEMPLATE CORRECTION ......................................................................... 14

SURFACE PREPARATION IMMEDIATELY PRIOR TO PAVING ....................... 14

HAULING AND TRANSPORTATION ............................................................... 17

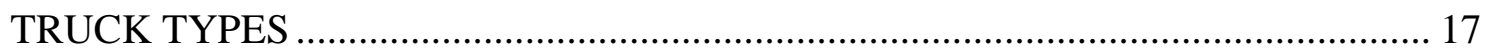

MECHANICAL CONDITION OF TRUCKS ...................................................... 18

CLEANNESS OF THE TRUCK BED ................................................................ 18

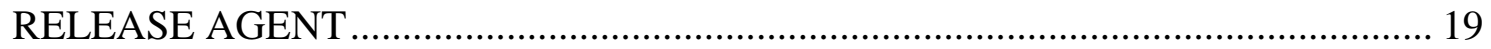

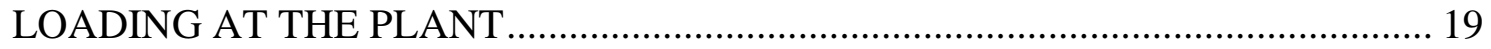

MATERIAL TEMPERATURE IN THE TRUCK.................................................... 20

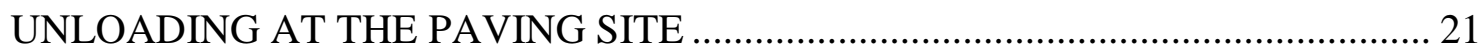

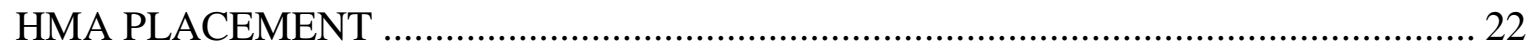

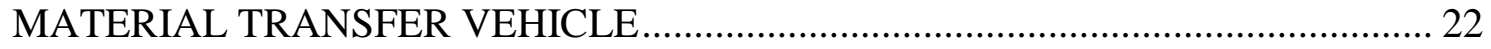

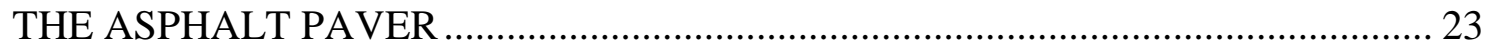

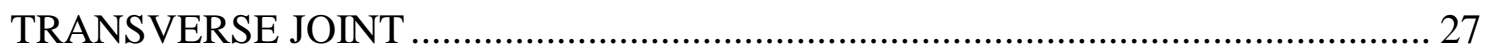

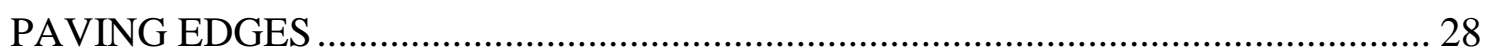

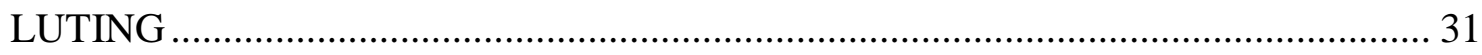

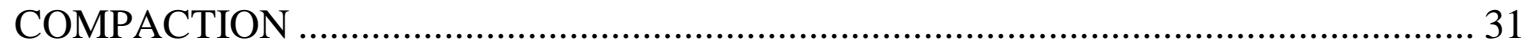

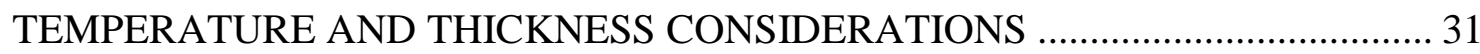

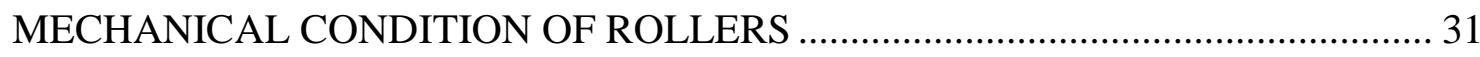

WATER SPRINKLE AND SCRAPERS .............................................................. 31

ROLLER PATTERN AND COMPACTION OF HMA ............................................ 31

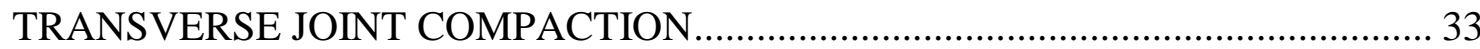

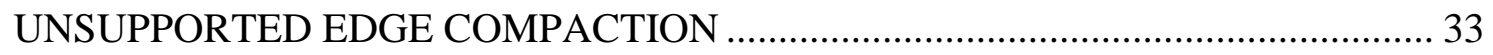

SUPPPORTED EDGE COMPACTION ............................................................... 34 


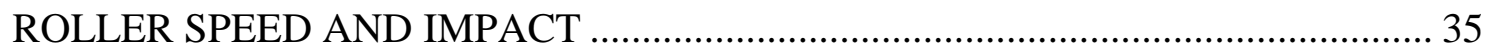

Chapter 3 RESEARCH METHODOLOGY ..................................................................... 36

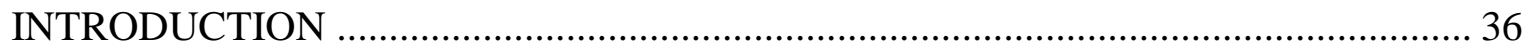

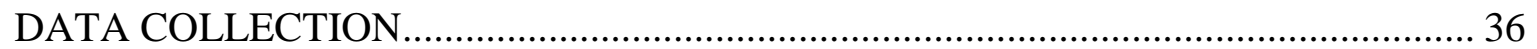

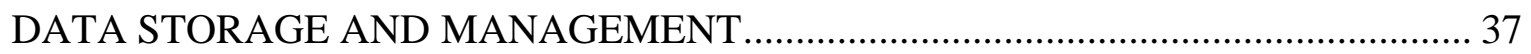

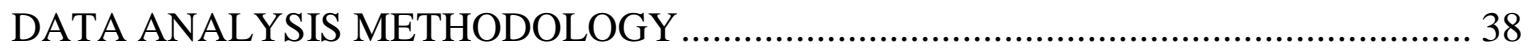

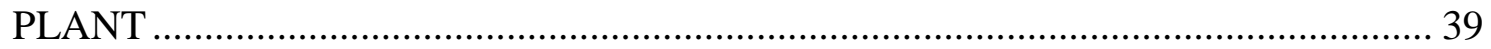

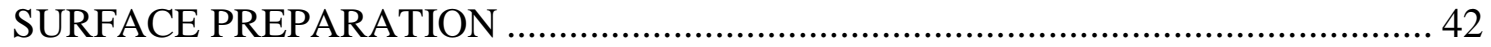

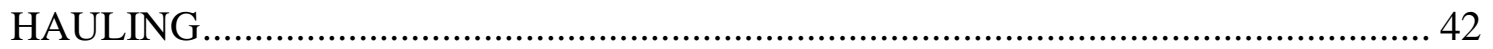

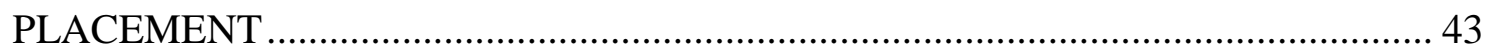

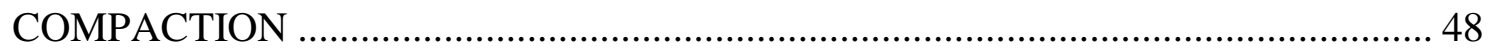

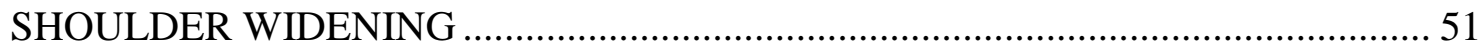

TRUCKS TRAVEL TIME AND TEMPERATURE .................................................. 51

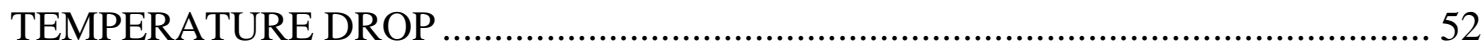

CONFIDENCE IN DATA AND PERFORMANCE .................................................... 52

Chapter 4 RESULTS AND ANALYSIS ……………....................................................... 53

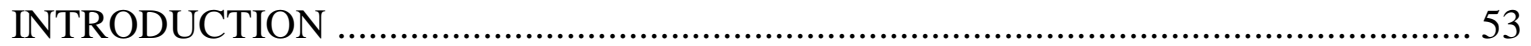

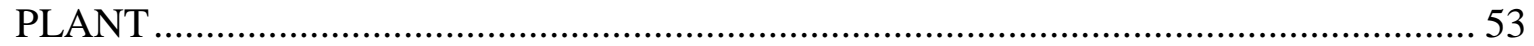

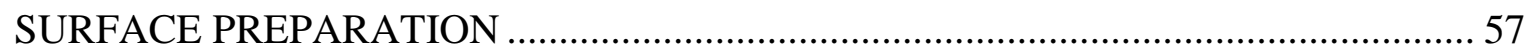

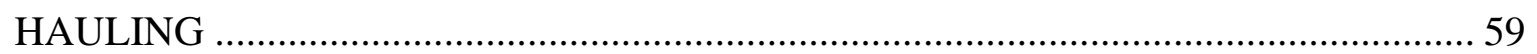

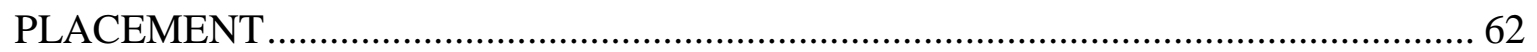

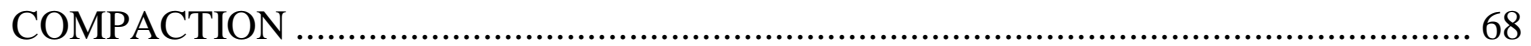

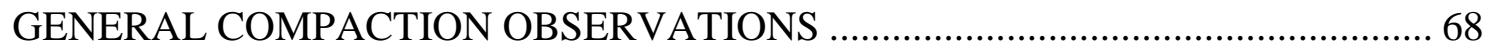

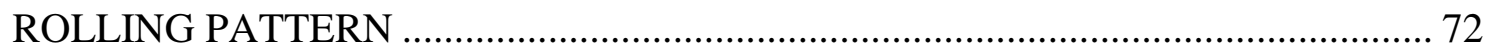

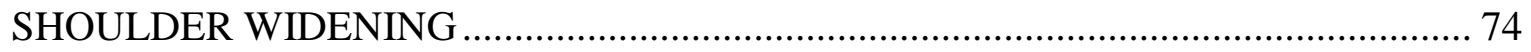

TRUCK TRAVEL TIME AND TEMPERATURE …………………………………..... 76

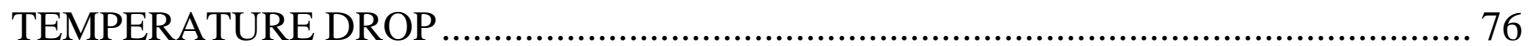

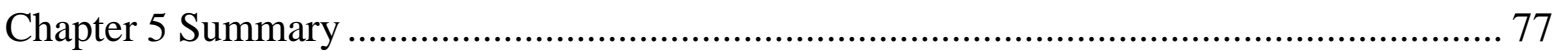

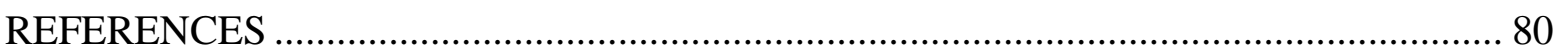

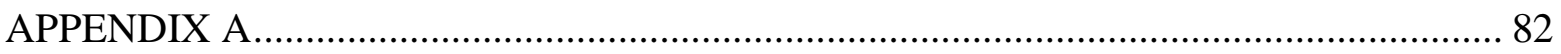

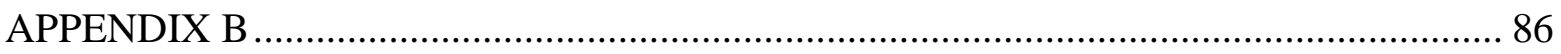

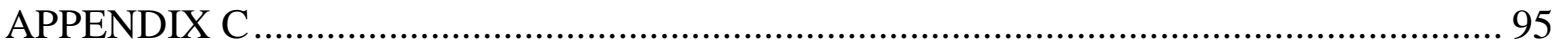




\section{LIST OF FIGURES}

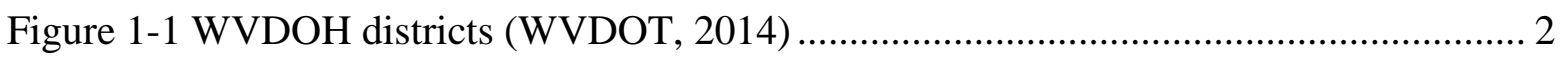

Figure 2-1 Contamination in the aggregate stockpile (GDOT, 2012) .................................. 5

Figure 2-2 Segregation in the aggregate stockpile (Geoengineer, 2014) ................................ 6

Figure 2-3 building stockpiles by trucks (GDOT, 2012)...................................................... 6

Figure 2-4 Building stockpile by conveyor/radial stacker (Direct Industry, 2014) ................ 7

Figure 2-5 Direction of loading from aggregate flow; base figure from NAPA ...................... 8

Figure 2-6 an ideal stockpiled (Simmons, undated) ………............................................... 9

Figure 2-7 Vertical dividers (Dunbar asphalt plant in WV) ............................................. 9

Figure 2-8 Horizontal and vertical tanks and relative footprint (Heatec, 2003)................... 11

Figure 2-9 Asphalt heating systems (Heatec, 2003) ........................................................... 12

Figure 2-10 batch plant (US Army COE, 2000)................................................................ 13

Figure 2-11 Drum mix plant (US Army COE, 2000) ………......................................... 13

Figure 2-12 Asphalt distributors (Webb, 2010)................................................................. 16

Figure 2-13 Proper nozzle angle setting (Asphalt Institute, 2010) ....................................... 16

Figure 2-14 Correct spray bar hight ( $\mathrm{h}=4$ inches) (Asphalt Institute, 2010) ......................... 17

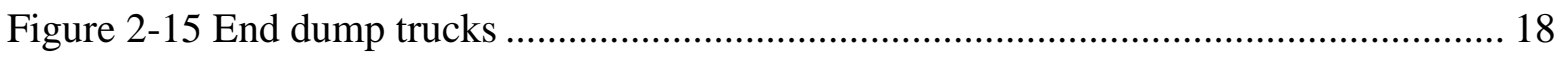

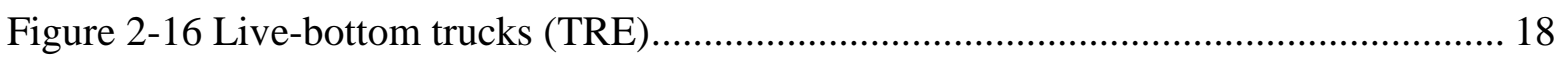

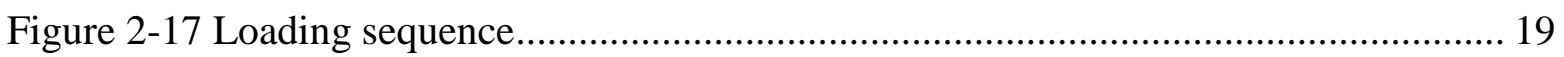

Figure 2-18 Best loading practice (Skinner 2005) ......................................................... 20

Figure 2-19 Tarp provides less heat loss (Pavement Interactive, 2014) ............................... 20

Figure 2-20 Proper loading of paver (Asphalt Institute, 2010) ............................................ 21

Figure 2-21 Material Transfer Vehicle without Remixing ...................................................... 22

Figure 2-22 Tracked and wheeled paver (Volvo Construction Equipment, 2014)............... 23

Figure 2-23 Tractor and screed in paver (Volvo Construction Equipment, 2014) ................ 24

Figure 2-24 Material flow path through the paver (Sunkenberg 2012) ................................ 24

Figure 2-25 Self-leveling screed and forces (Asphalt Institute, 2010) ................................. 26

Figure 2-26 Correct and incorrect mix levels in paver auger chamber ................................ 27

Figure 2-27 Butt joint (US Army COE, 2000) …………............................................... 28

Figure 2-28 Wedge Joint (Pavement Interactive) ……………………………................... 29 


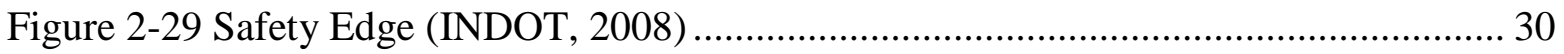

Figure 2-30 Overlapped joints (Us Army COE, 2000)..................................................... 30

Figure 2-31 Pass and Coverage for a paved lane (Asphalt Institute, 2010) .......................... 32

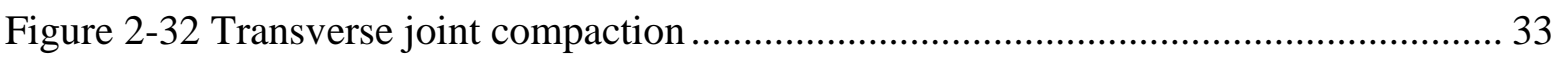

Figure 2-33 Unsupported edge compaction (WVDOH, 2013)............................................ 34

Figure 2-34 Longitudinal joints compaction (Pavement Interactive, 2014) .......................... 34

Figure 2-35 Longitudinal joints compaction, picture modified ............................................ 35

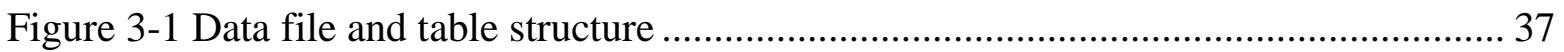

Figure 3-2 Stockpile separation, Good/Fair/Poor practices................................................. 41

Figure 3-3 Stockpile base condition, Good/Fair/Poor practices .......................................... 41

Figure 3-4 Tack coat uniformity, Good/Fair/Poor practices ............................................... 46

Figure 3-5 Material distribution across the auger, Good/Poor practices ............................... 46

Figure 3-6 Surface texture behind the paver, Good /Poor practices ....................................... 47

Figure 3-7 Luting, Good/Fair/Poor practice ................................................................... 47

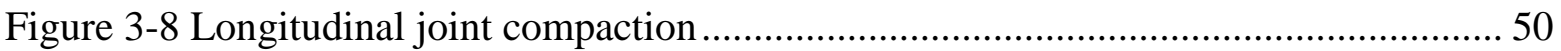

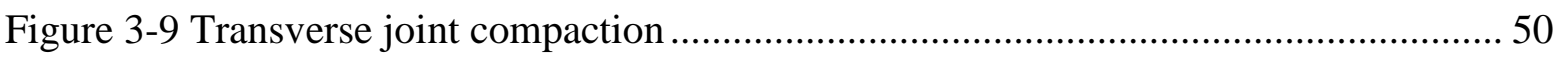

Figure 4-1 Plant operations performances in summer 2012 and 2013 ................................ 55

Figure 4-2 Comparison between stockpile segregation conditions in 2012 and 2013 .......... 55

Figure 4-3 Comparison between stockpile separation conditions in 2012 and 2013 ............ 55

Figure 4-4 Comparison between stockpile contamination condition in 2012 and 2013 ....... 56

Figure 4-5 Comparison between stockpile's base conditions in 2012 and 2013 ................... 56

Figure 4-6 Comparison between "aggregate falling into adjacent bins while loading" ........ 56

Figure 4-7 Comparison between spillage from conveyors in 2012 and 2013 ...................... 57

Figure 4-8 Surface preparation performances in summer 2012 and 2013.......................... 58

Figure 4-9 Comparison between surface being dry before paving in 2012 and 2013 ........... 59

Figure 4-10 Comparison between surface being clean before paving in 2012 and 2013 ...... 59

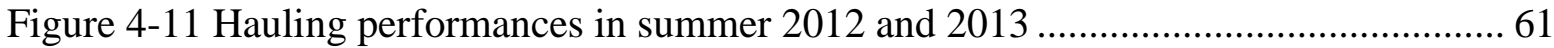

Figure 4-12 Comparison between proper release agent used in trucks in 2012 and 2013 .... 61

Figure 4-13 Comparison between loading sequences for trucks in 2012 and 2013 .............. 61

Figure 4-14 Placement performances in summer 2012 and 2013 ...................................... 64

Figure 4-15 Comparison between tack coat uniformity in 2012 and 2013 .......................... 64 
Figure 4-16 Comparison between tack coat break in 2012 and 2013 .............................. 64

Figure 4-17 Comparison between material delivery in 2012 and 2013 ............................. 65

Figure 4-18 Comparison between screed setup at beginning of paving in 2012 and 2013 ... 65

Figure 4-19 Comparison between truck and paver connection in 2012 and 2013 .............. 65

Figure 4-20 Comparison between hopper overflow in 2012 and 2013 ............................ 66

Figure 4-21 Comparison between material distribution across the auger in 2012 and 201366

Figure 4-22 Comparison between hopper wings in 2012 and 2013 ............................... 66

Figure 4-23 Comparison between thickness checked during paving in 2012 and 2013 ....... 67

Figure 4-24 Comparison between surface texture behind the paver in 2012 and 2013 ....... 67

Figure 4-25 Comparison between truck bed cleaning after loading in 2012 and 2013 ........ 67

Figure 4-26 Comparison between luting condition in 2012 and 2013 ............................. 68

Figure 4-27 Compaction performances in summer 2012 and 2013 ................................ 70

Figure 4-28 Comparison between stopping on hot material in 2012 and 2013 ................. 70

Figure 4-29 Comparison between visible roller marks after compaction in 2012 and 2013.71

Figure 4-30 Comparison between transverse joint compaction in 2012 and 2013.............. 71

Figure 4-31 Comparison between Longitudinal joint compactions in 2012 and 2013 ......... 71

Figure 4-32 Shoulder widening performances in summer 2012 and 2013 ....................... 75 


\section{LIST OF TABLES}

Table 2-1 Advantages and disadvantages among tracked and wheeled pavers................... 23

Table 3-1 Summary and description of the front-end file (data tables)............................ 38

Table 3-2 Phrase description and recommended practice for plant inspection categories ... 40

Table 3-3 Phrase description and best practice for hauling categories .............................. 42

Table 3-4 Phrase description and best practice for hauling categories............................. 43

Table 3-5 Phrase description and recommended best practice for placement categories..... 44

Table 3-6 Phrase description and recommended best practice for placement categories..... 45

Table 3-7 Phrase description and recommended best practice for compaction categories ... 49

Table 3-8 Phrase description and recommended best practice for shoulder widening......... 51

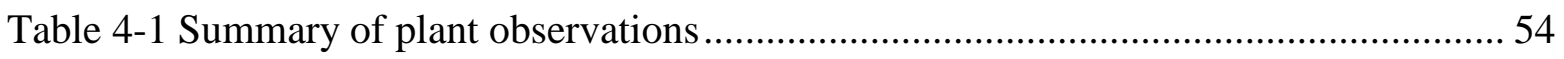

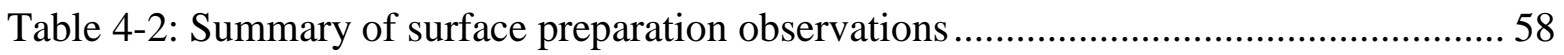

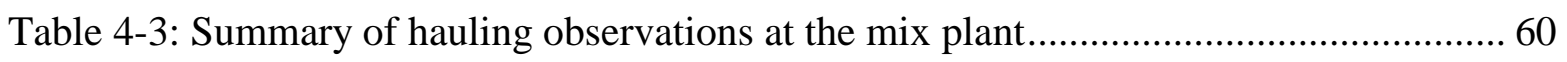

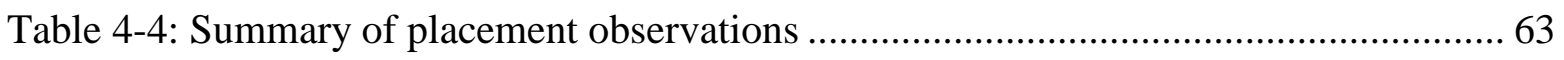

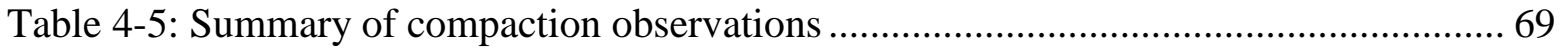

Table 4-6 Number of passes for first rollers ............................................................. 73

Table 4-7 Number of passes for second rollers ......................................................... 74

Table 4-8: Summary of shoulder widening observations ............................................ 75 


\section{CHAPTER 1 INTRODUCTION}

\section{INTRODUCTION}

In 2010, about160 billion dollars were spent to build and maintain 4 million miles of public roads in the United States (Congress of the US, 2012). Highway pavement construction is dominated by rehabilitation and resurfacing. Good construction practices are important contributor to asphalt pavement performance. It is important during asphalt pavement construction that materials and constructed products meet the specification requirements. Contractors and inspectors must understand materials, mix design, and construction practices to ensure specification are met. Due to the complexities of asphalt pavement construction, not all requirement activities can be captured with specifications. Highway agencies, including the West Virginia Division of Highways, WVDOH, rely on contractors to use good practices and methods for the construction of pavements.

In many cases, there are certain practices which have been demonstrated to provide pavement with the best performance. Collectively these procedures are generally described as best management practices, BMP. To ensure contractors and WVDOH inspectors are knowledgeable about the construction specification and BMPs, the division offers two workshops annually; one for plant personnel and the other for field personnel. The confluence of the complexity of pavement construction, some concerns with the performance of recently constructed projects, and the training emphasis lead the WVDOH to identify a need to monitor the pavement construction process.

\section{PROBLEM STATEMENT}

West Virginia Department of Highways (WVDOH) decided to review construction practices as the Project RP-285 Construction Practices Review. Figure 1-1 shows the 10 WVDOH districts. The WVDOH hired 4 co-ops during summer 2012, and several pavement projects were monitored in the Districts 1, 2, 3, 4 and 5. An interim report on the analysis of the 2012 observation was prepared and presented to the WVDOH and the paving industry. Based on the result of the 2012 study the WVDOH decided to continue the study and hired two co-op students for the summer of 2013. Projects in districts 1,3, 4, 7, and 9 were observed. This report presents 
an analysis of all the information collected during both summers and provides comparison of the two sets of observations.

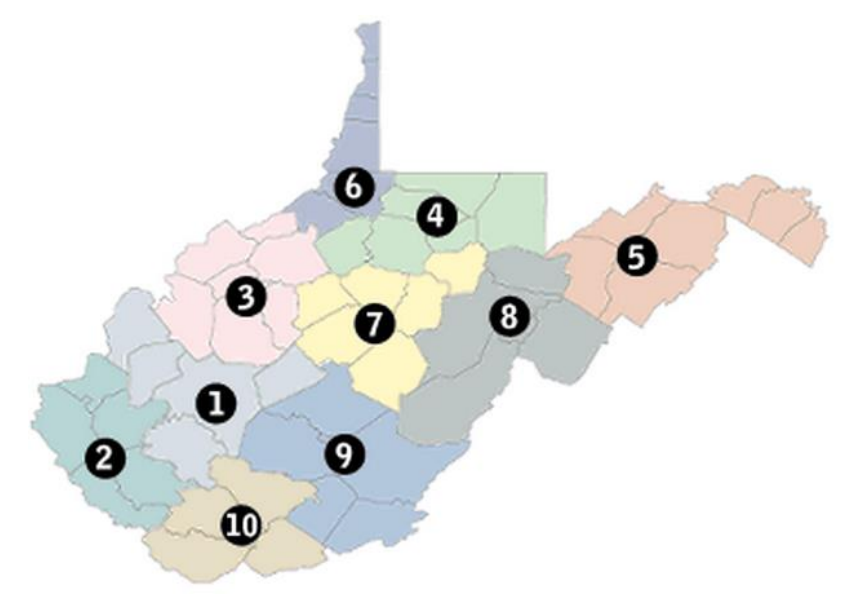

Figure 1-1 WVDOH districts (WVDOT, 2014)

\section{OBJECTIVE}

The broad objective of the research project is to improve the quality of asphalt pavement construction in the state. The first step in this process is to establish a baseline metrics of the current construction practices. The objective of this thesis is to use the observations recorded in the summer of 2012 and 2013 to provide the baseline metrics. For comparative purpose it is desirable to document the best practices for pavement construction. There are many sources of this information. Therefore, compiling these practices into a format that can be readily transmitted to contractors and WVDOH personnel was also an objective of this thesis.

\section{SCOPE AND LIMITATIONS}

This research study was limited to observing pavement construction projects in West Virginia including District 1, 2, 3, 4, 5 in summer 2012 and 1, 3, 4, 7, 9 in summer 2013. The scope of the evaluated projects should include a wide range of contractors, highway types, and project types. However, in reality the co-op assignments were constrained by the availability of projects within a reasonable travel distance. This limited the ability to capture data for all the desired combination of observation.

\section{THESIS STRUCTURE}

This thesis is divided into five chapters. Following the introduction, Chapter 2 focuses on asphalt construction specification and practices. Chapter 3 outlines the research methodology 
used for data recording and analysis. Chapter 4 contains the results from the observed data as outline in Chapter 3. Chapter 5 finishes by presenting conclusions. The appendix contains data forms, Microsoft Access and best construction practices. 


\section{CHAPTER 2 LITERATURE REVIEW}

\section{INTRODUCTION}

The asphalt pavement construction quality is important to the long-term pavement performance. Poor construction practices have a devastating effect on pavement performance. In this chapter high quality construction practices are described in 5 categories:

- Hot mix asphalt plant operations

- Surface preparation

- Hauling

- Placement

- Compaction

\section{HOT-MIX ASPHALT PLANT OPERATIONS}

Asphalt concrete production is the first step in construction and it takes place in the plant. Aggregates and asphalt binders are heated, and blended to produce an asphalt concrete that meets the all requirements of the job mix formula (Roberts et al., 1996).

\section{AGGREGATE STOCKPILES}

Aggregates are stored at plant site before transferring into cold feed bins. Appropriate aggregate placement and removal from the stockpile should be carefully considered. Following concerns should be taken into account about stockpiles:

- Contamination

- Segregation

- Stockpile moisture control

\section{Contamination}

As shown in Figure 2-1, a stockpile may be contaminated in various ways. For example; debris from external sources such as leaves, soil from the subgrade, and mixing with aggregates from adjacent stockpiles all cause contamination. 

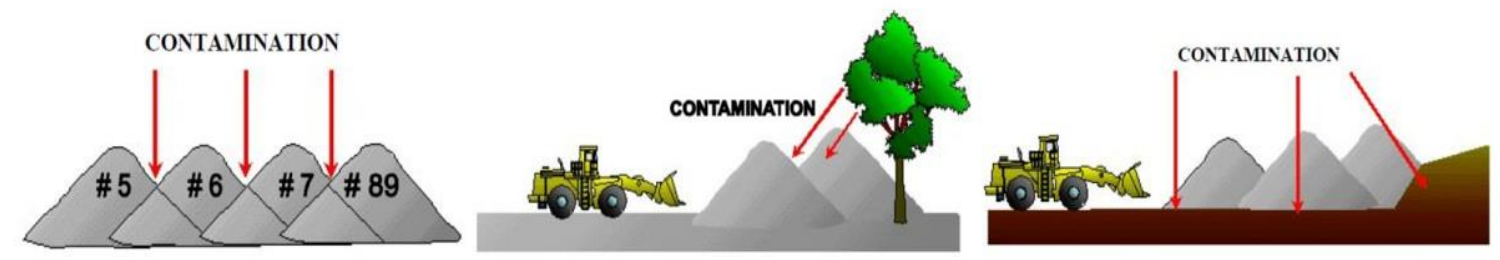

Figure 2-1 Contamination in the aggregate stockpile (GDOT, 2012)

- Cross Contamination: Aggregates of different sizes should be stockpiled separately. Stockpiles should be separated by vertical dividers or enough space to prevent cross contamination (Asphalt Institute, 2010).

- Subgrade Contamination: Sometimes the bucket of a front-end loader picks up subgrade material along with the desired aggregate. If the contaminated material is placed in a cold feed bin the asphalt concrete produced with the contaminated material will be defective. To avoid this problem, the ground below the stockpiles should be stabilized or placed on a base aggregate-type to reduce subgrade contamination (Asphalt Institute, 2010, US Army COE, 2000).

- Wheel and Track Contamination: Subgrade around the stockpiles can stick to the wheels or tracks of stockpiling equipment. This material can contaminate aggregate stockpiles as the equipment operates on or around the stockpiles (Asphalt Institute, 2010).

\section{Segregation}

Stockpiles should be built properly to provide unsegregated material for plant. Segregation can happen whenever aggregates non-uniform gradations are moved. Poor stockpiling techniques result in larger particles rolling to the bottom of the stockpile leaving the fines behind, Figure 22. This separation of different sizes is segregation (Asphalt Institute, 2010). There should be care about the height of stockpiles. High stockpiles are prone to segregation because large aggregate particles tend to roll down from higher piles. It is recommended to build stockpile materials with same size in different piles to minimize segregation (NAPA, 1996). Material should not be stockpiled over larger size aggregate. They should be stockpiled over the same size or similar aggregate (GDOT, 2012). 
Stockpiles can be constructed by truck, conveyor and radial stacker:

Trucks: Material should be dumped in single piles Figure 2-3-a. In the case of using ramping to build stockpiles, trucks are not allowed to dump or push material over the edge of ramp Figure 2-3-b. The stockpile ramp size should be minimized and it should not be longer than required. The top of each pile should be flattened to facilitate the transportation of next pile onto the stockpile. If a stockpile is built in several layers, the layers should be placed in same thickness all over the stockpile (NAPA, 1996, GDOT, 2012).

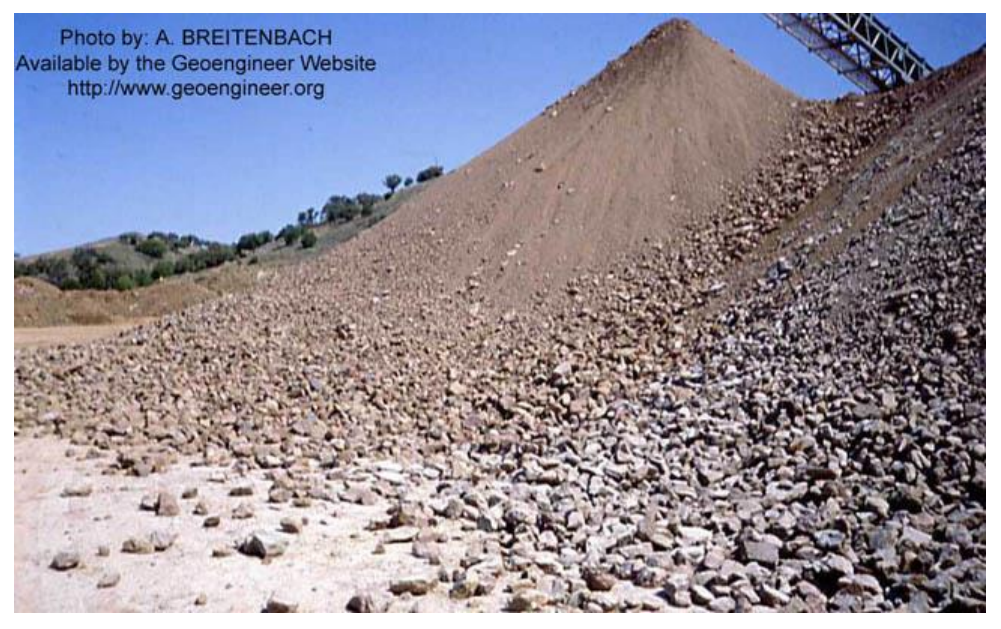

Figure 2-3 Segregation in the aggregate stockpile (Geoengineer, 2014)

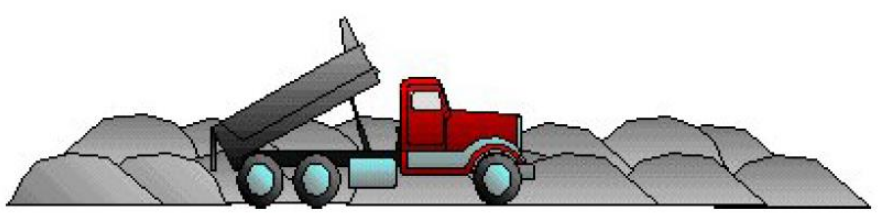

a) Dump material in single piles

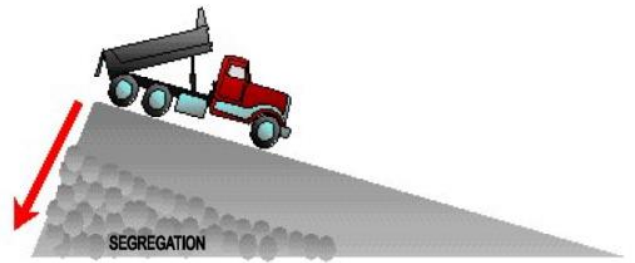

b) Do not dump material over the edge

Figure 2-4 building stockpiles by trucks (GDOT, 2012) 
Conveyors: conveyors, Figure 2-4-a, can also cause segregation; strong wind can carry the finer aggregate particles to one side of the pile. Additionally, larger aggregate particles with more momentum can fall to the outside edge of the pile due to the speed of conveyor (INDOT, 2013). Conveyors can also minimize the cost of equipment and personnel.

A radial stacker: A radial stacker, Figure 2-4-b, can ensure that aggregates are continuously discharged at top of the stockpile in separate layers. It also can minimize the high elevated cone shape that can lead to segregation in stockpiles. It can also minimize the cost of equipment and personnel. The stacker tail should not move forward and back while the stacker rises and lower to prevent spillage from the conveyor. This spillage can also cause segregation (Foster, 2011).

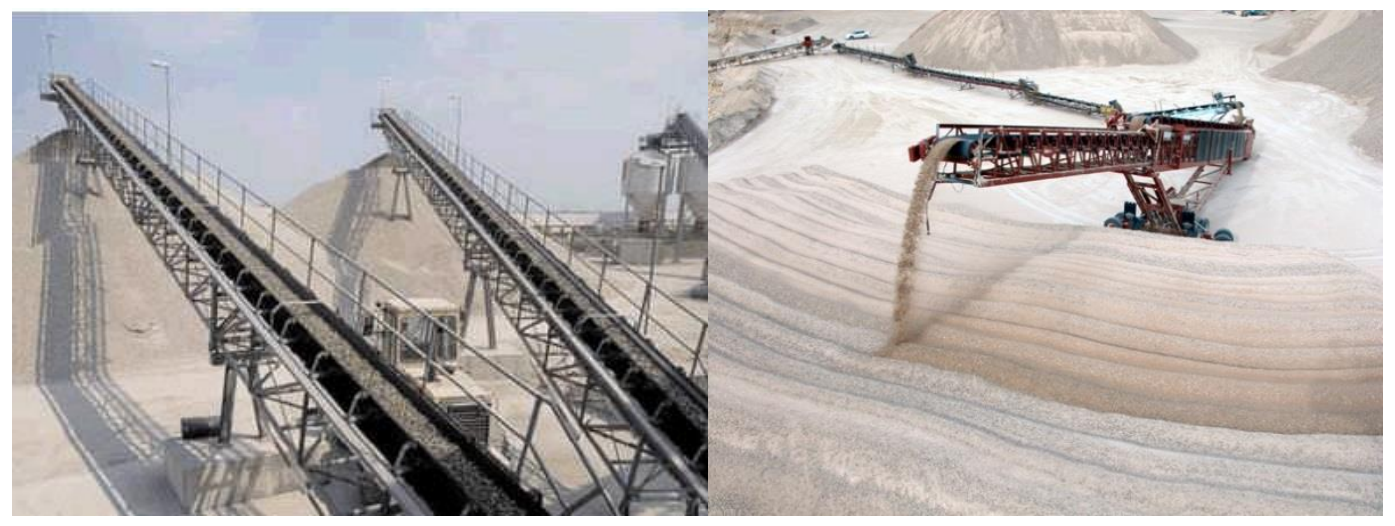

a) Conveyor belt

b) Radial stacker

Figure 2-5 Building stockpile by conveyor/radial stacker (Direct Industry, 2014)

Improper Loading of material from stockpile can also cause segregation. Aggregate should be removed in a direction that is perpendicular to the aggregate flow Figure 2-5. In another word, loader should not load from current production. It is due to large aggregate particles tending to accumulate at outside edge of conveyor in direction to the conveyor (NAPA, 1996, GDOT, 2012). 


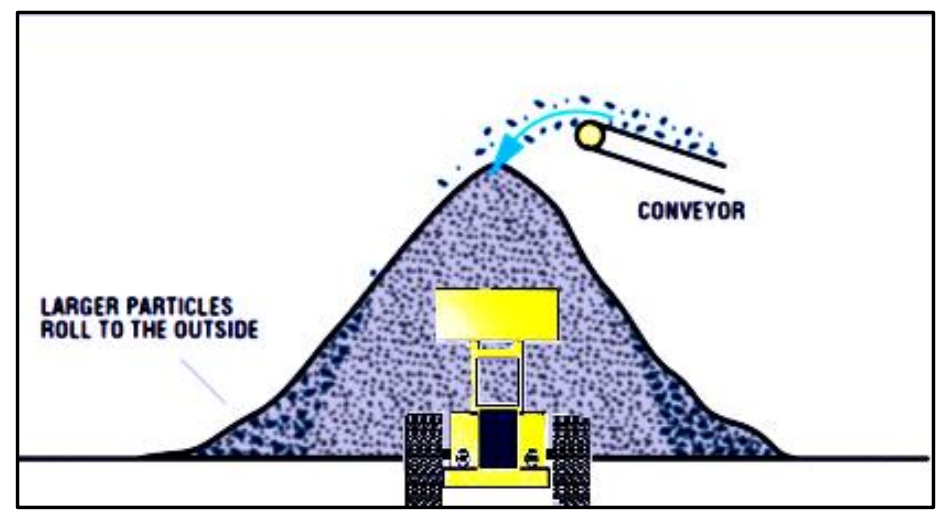

Figure 2-6 Direction of loading from aggregate flow; base figure from NAPA, modified to show front end loader (NAPA, 1996)

\section{Stockpile Moisture Control}

Consistent moisture control of stockpiles allows consistent plant operation. Aggregates moisture can affect plant production due to change in mix temperature during plant operation. It is necessary to determine the moisture content of stockpiles at least twice a day (US Army COE, 2000). In addition, higher moisture content in aggregate takes them longer time and higher energy to dry, thus it increases the cost on the producer. It is recommended that aggregate are stockpiled on a solid draining surface to allow drainage (Asphalt Institute, 2010 and Simmons, undated). This solid surface should be sloped. The loader should remove the aggregate from the upside of the sloped pile due to lower moisture content (WVDOH, 2002). An ideal stockpiled is depicted in Figure 2-6 that aggregate was removed from its upslope side (Simmons, undated). Additionally, for fine aggregate stockpiles which tend to absorb the moisture and do not let the water to drain easily, providing roof during the rainy seasons is recommended (US Army COE, 2000). 


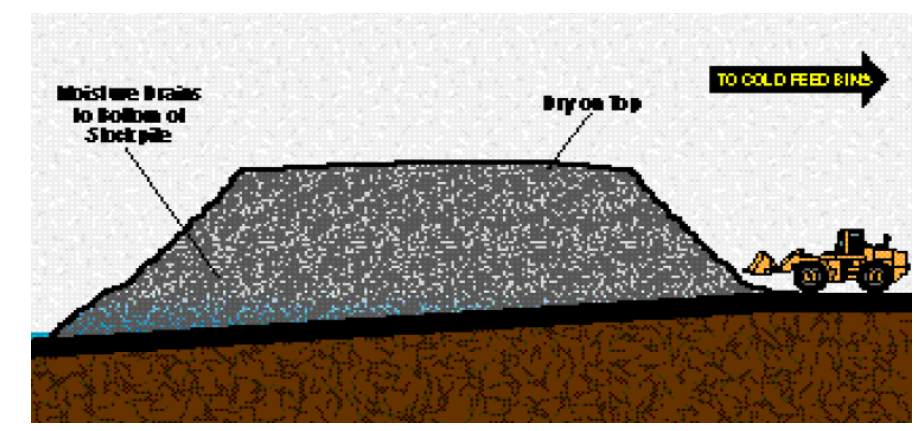

Figure 2-7 an ideal stockpiled (Simmons, undated)

\section{COLD FEED SYSTEM}

Stockpiled aggregates are fed into the cold feed bins for delivery to the aggregate dryer. Each bin generally holds a separate aggregate size or gradation and has adjustable gate that meters aggregate into a moving conveyor belt. Improper loading of cold bins may result in overflowing and contamination. Cold bins need to be kept full of aggregate but do not overfill. Vertical dividers as shown in Figure 2-7, are supposed to help avoid mixing materials from adjacent cold bins which will cause contamination in aggregates (US Army COE, 2000).

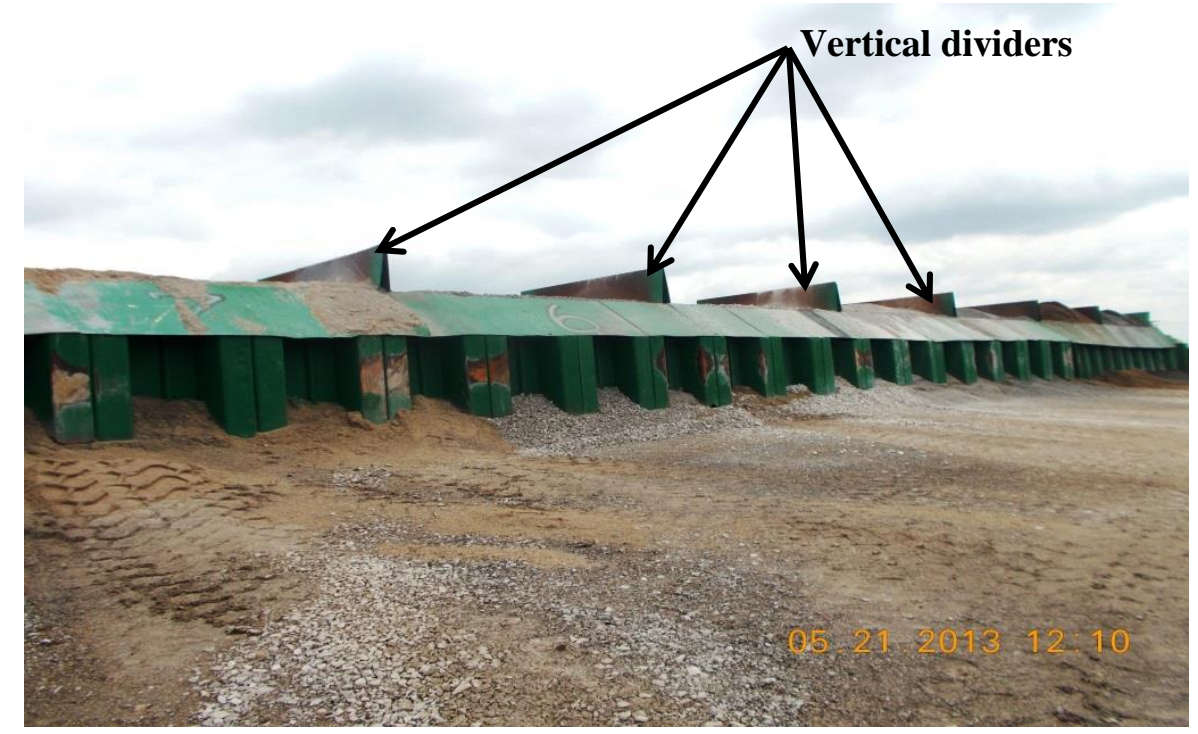

Figure 2-8 Vertical dividers (Dunbar asphalt plant in WV) 
Aggregate material is transferred between cold feed bins and plant by conveyor. Spillage from conveyor causes miss-matching of the pre-set discharge rates with the actual delivery rates of the aggregates from different sizes or the blend, which might lead to change in the gradation. Spillage from conveyors can be minimized by installing appropriate wind guards to reduce the effect of the wind on conveyors. The quality of material should be monitored periodically by sampling from conveyor in order to determine aggregates moisture and gradation. This should be done on a regular basis (Asphalt Institute, 2010).

\section{BINDER STORAGE}

The asphalt properties of the binding agent in asphalt concrete significantly changes with aging. Moreover, a considerable amount of asphalt aging occurs during the Hot Mix Asphalt (HMA) production. Improper handling and storage of asphalt binder may cause repeated cooling and heating, thermal fluctuations, overheating and oxidation which all result in premature aging. Therefore, special care must be paid toward asphalt storage on site (Asphalt Institute, 2010, US Army COE, 2000).

\section{Horizontal and Vertical Tanks}

Asphalt binder is stored inside horizontal or vertical insulated tanks that heated and maintain the asphalt binder at the proper mixing temperature Figure 2-8. Vertical tanks reduce oxidation of the asphalt due to the less surface area of the asphalt exposed to the air inside the tank compared to the horizontal tanks. This gains higher importance when dealing with polymer modified asphalt (PMA), which has higher oxidization susceptibility since it requires higher temperature for storage and handling (Asphalt Institute, 2010, US Army COE, 2000). Vertical tanks occupy less area on the plant site, for example, four vertical tanks have the same foot print as one horizontal tank, Figure 2-8-c, (Heatec, 2003). 


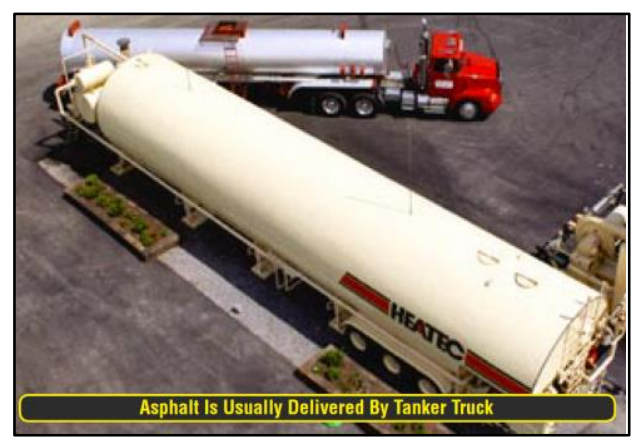

A

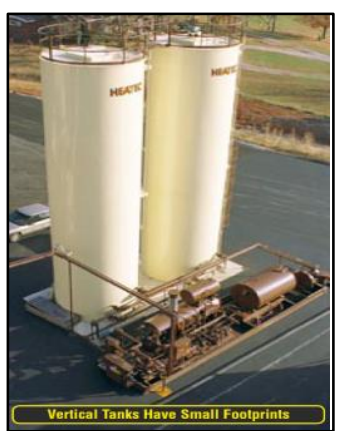

B

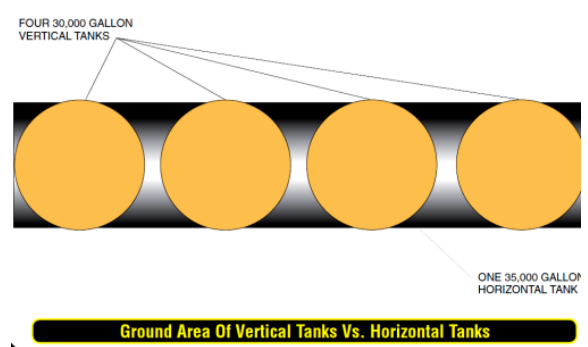

$\mathrm{C}$

Figure 2-9 Horizontal and vertical tanks and relative footprint (Heatec, 2003)

\section{Tank Mixers}

Polymer modified asphalt (PMA) needs to be agitated continuously while stored in the tank to avoid polymer settlement. Therefore PMA storage tanks are required to be equipped with mixers (Asphalt Institute, 2010).

\section{Tanks and Pipes Insulation}

Lack of sufficient insulation may cause overheating the asphalt to maintain the operational temperature and viscosity, in addition to energy waste and inefficiency of the plant (Asphalt Institute, 2010).

\section{Heating Methods}

Direct-fired tank is an asphalt storage tank that has a burner mounted on one end of the tank. The burner fires directly into a fire tube which is fully in contact with asphalt. In this method there is potential for overheating asphalt in the areas close to fire tube. The other type of heating widely used is an indirect system. It circulates hot oil through a heating coil which is immersed in the asphalt. The latter technique reduces the chance of overheating of asphalt in the tank (US Army COE, 2000). Cross sections of both methods are displayed in Figure 2-9. Only the hot oil circulation method is used for vertical tanks (Heatec, 2003). 


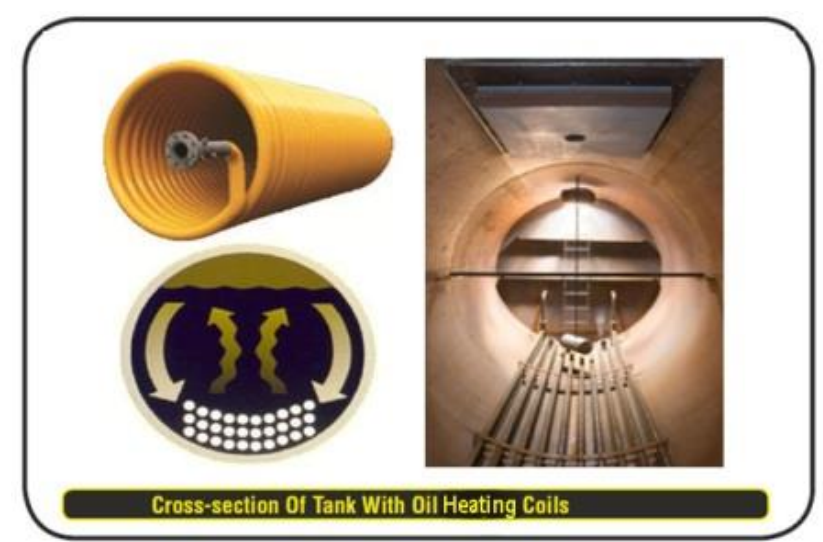

Oil Heating coil

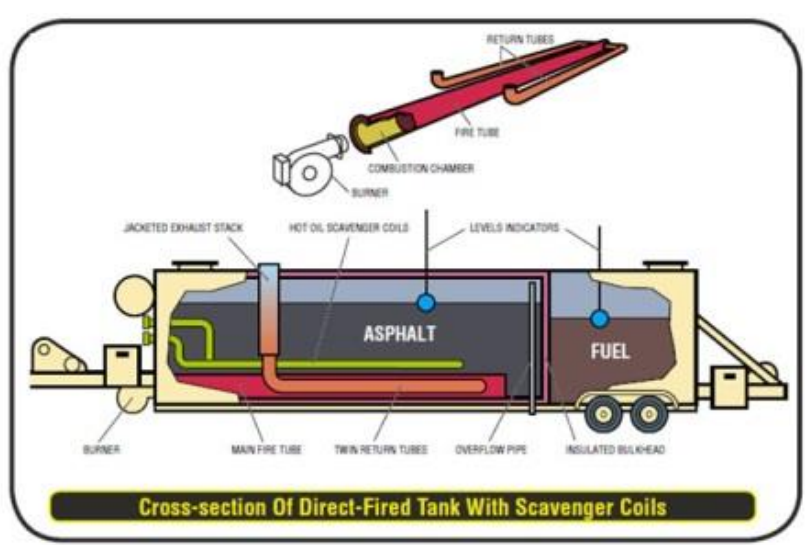

Direct-fired tank

Figure 2-10 Asphalt heating systems (Heatec, 2003)

\section{ASPHALT MIXING PLANTS}

Asphalt mixing plants can be broadly classified as either batch plants or drum plants (Asphalt Institute, 2010). Batch-mix plants produce asphalt concrete in individual batches and the drum plants produce asphalt concrete in continuous operations. There are four styles of continuous plants, single drum with parallel flow, single drum with counter flow, dryer-drum, and double barrel. Figure 2-10 shows a typical batch plant. Figure 2-11 shows a single drum parallel flow plant; other continuous flow asphalt plants have a similar arrangement with the differences being in the design of the dryer and coating drum system. Since there was little the co-ops could observe relative to the performance and operation of the different types of mixing plants, the details of plant operation are not reviewed in this document.

\section{SURFACE PREPARATION}

The final product of a paving project depends on the quality of the surface prior to overlay. Three issues need to be addressed: repair of the pavement structure and drainage issues, template correction and preparation of the surface immediately prior to the overlay.

\section{REPAIR OF THE PAVEMENT STRUCTURE AND DRAINAGE ISSUES}

Overlays should be placed on structurally sound pavements areas without base failures and fatigue cracking. Major pavement distresses such as base failures, potholes, alligator and block cracking should be fixed prior to resurfacing to avoid reflective cracking. Rutted areas should be 


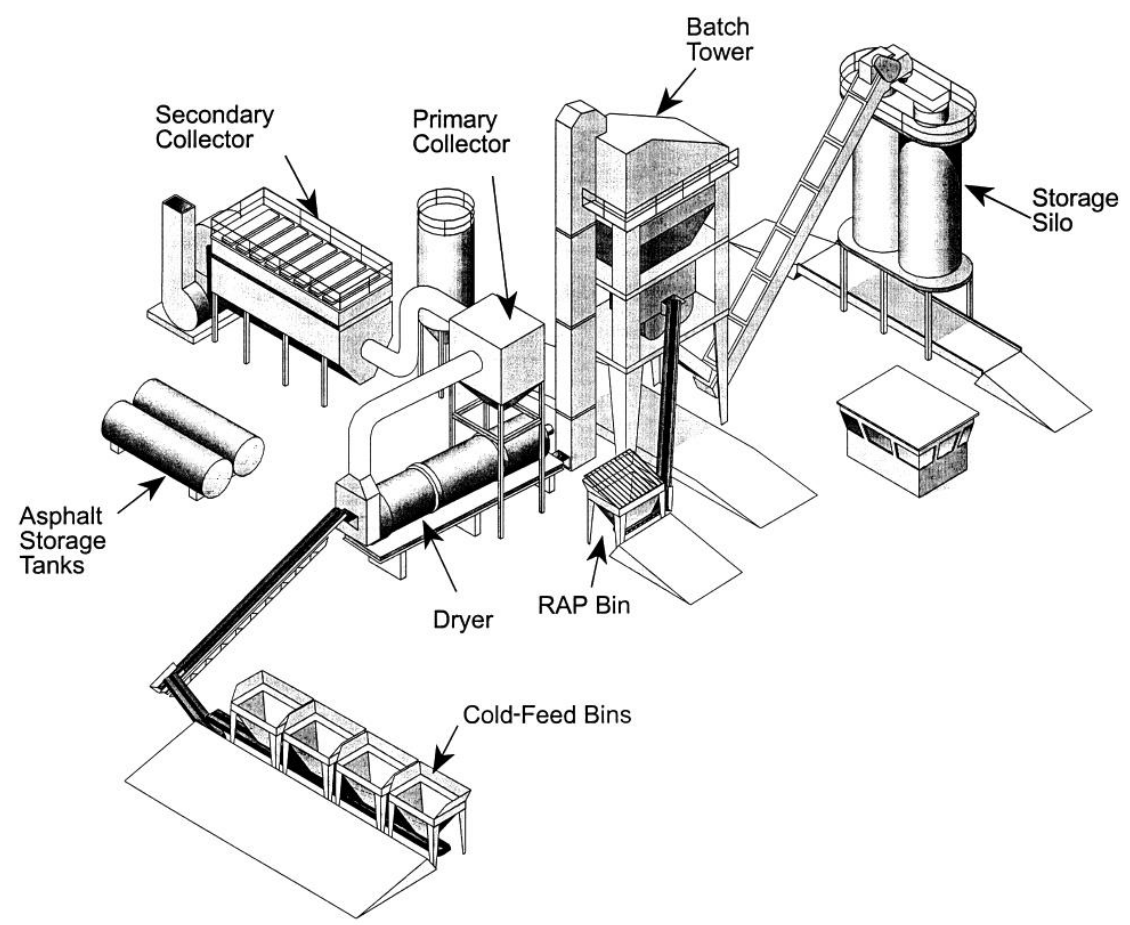

Figure 2-11 batch plant (US Army COE, 2000)

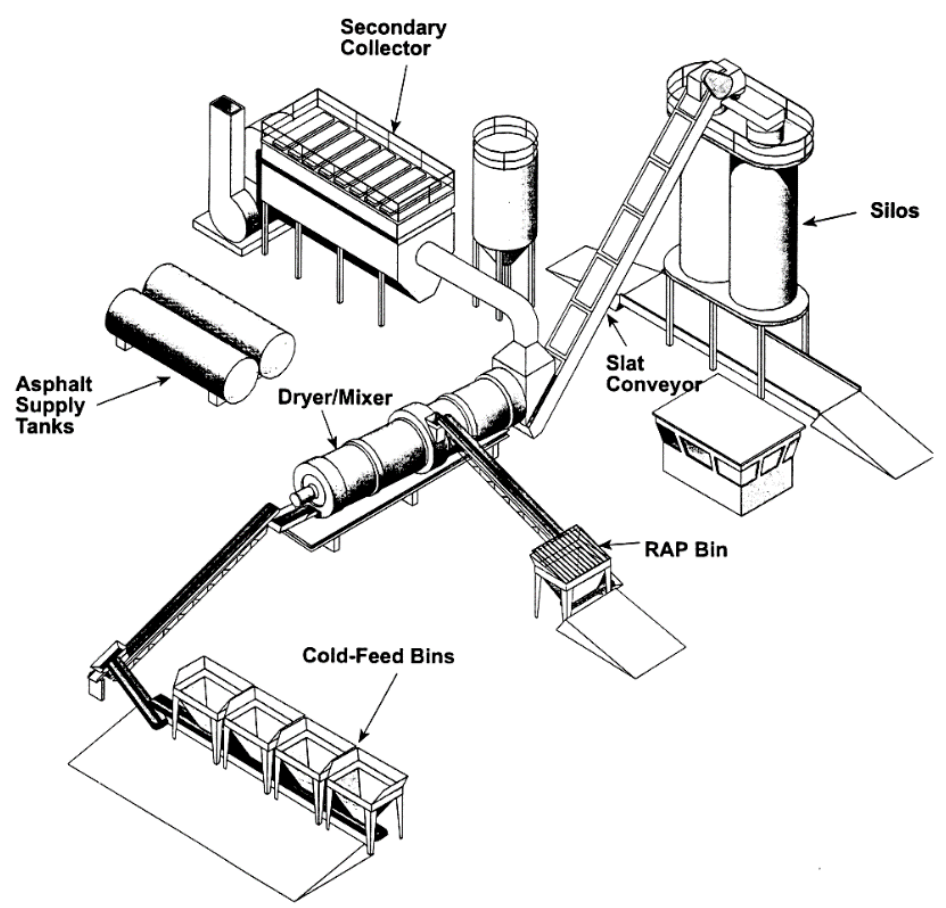

Figure 2-12 Drum mix plant (US Army COE, 2000) 
repaired unless milling is used for template correction. Ideally, structural repairs should be performed in advance of a construction project to allow the patches to "cure" and consolidate. However, this requires traffic control costs that may results in these activities being carried out as part of the construction project. Drainage issues should be considered, and care should be done to prevent damage against drainage utilities and facilities alongside roadways (WVDOH, 2002).

\section{TEMPLATE CORRECTION}

Template repair is adjusting the pavement elevation to provide a uniform surface for the overlay. The most common types of template repair are patch and level, scratch course, or milling. Template corrections are generally performed as part of the construction contract (WVDOH, 2002).

- Patching and Leveling: Uneven pavement surfaces are leveled by placing patching course. The purpose is to correct surface irregularities and elevate the existing outside edge to obtain a uniform template.

- Milling: It is the controlled cold grinding of pavement to return the surface to a specified profile. Small ruts, bumps and other surface distresses are removed; consequently, the uniform textured surface will remain.

- Scratch course: The first lift applied to the existing pavement in order to fill in ruts and even up elevation differences.

\section{SURFACE PREPARATION IMMEDIATELY PRIOR TO PAVING}

Immediately prior to placing the overlay, or wearing course, the surface should be sound, "relatively" smooth, clean and a tack coat is used for bonding the overlay to the surface.

\section{Weather Considerations}

In wet weather situation the laydown surface should be dry without standing water. If the surface is wet, paving should be prohibited. When the ambient temperature falls below $40^{\circ} \mathrm{F}$ $\left(4^{\circ} \mathrm{C}\right)$ paving is not permitted (WVDOH, 2002).

\section{Cleaning the Surface}

The paving surface must be cleaned of all dust, dirt by using multiple passes of a mechanical broom and flushing with air or water (US Army, 2000, WVDOH, 2002). Milled surfaces are a challenge to clean due to the texture. Generally, cleaning a milled surface will require more 
passes of the broom to clean; it may be necessary to wet the surface to aid in cleaning (US Army, 2000)

\section{Tack Coats}

A tack coat is an asphalt material sprayed onto the surface to promote bonding between the existing and new layers. In West Virginia tack coats are generally emulsions and that is the only material discussed in the following. Tack coat should not be applied to a wet surface or during wet or cold weather situation. It is important to apply very thin layer of tack coat uniformly to the entire surface of the area to be paved (US Army, 2000, and WVDOH, 2002).

The bituminous amount in the truck and the temperature should be determined before and after application. Temperature gauge, pressure gauges, spray bar and application rate should be checked periodically.

Time is needed to allow the water in the tack coat evaporates; the color changes from brown to black as the tack coat sets or breaks. The tack coat should be fully set before the haul trucks are allowed on the surface (WVDOH, 2002).

\section{Asphalt Distributor}

A tack coat can be distributed over the surface by the asphalt distributor Figure 2-12. The main purpose is to apply the asphalt products (cutback or emulsion) in precise amount uniformly. The asphalt distributor is a truck or trailer mounted insulated asphalt tank with a heating system to keep the asphalt spraying temperature properly. Asphalt can be applied over the surface by system of spray bars with nozzles. These spray bars can usually cover widths of 6-30 feet (1.8$9.1 \mathrm{~m}$ ) in one pass. In addition, the correct size nozzles for different type and grade of asphalt and the application rate should be selected. Since the application rate for tack coats is much lower than other emulsion spray applications, generally the smallest nozzle size offered by the manufacture is the proper nozzle for tack coat application. The asphalt is delivered to the spray by gear-type pumps. The pressure made by these pumps can be controlled with constant speed pump and a pressure-relief valve or governed by a variable-speed pump. Maintaining the proper pressure is essential otherwise, non-uniform distribution of material will be occurred. In order to avoidance of the spray fans do not interfere with each other, the angle of the long axis of the nozzle opening must be adjusted Figure 2-13. This nozzle angle depends on the distributor model 
or make and it is normally between 15 and 30 degrees. It is also important to properly adjust the height of the spray bar above road surface to ensure uniform asphalt distribution. Figure 2-14 presents the correct spray bar hight for ensuring double and triple coverage (Asphalt Institute, 2010).

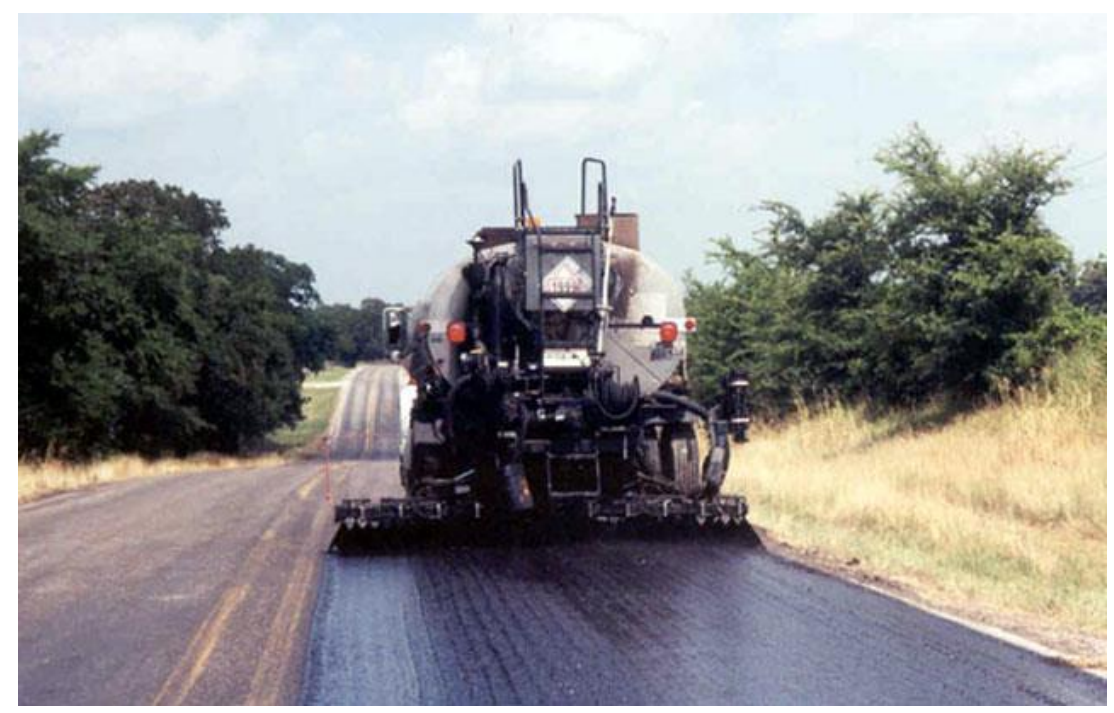

Figure 2-13 Asphalt distributors (Webb, 2010)

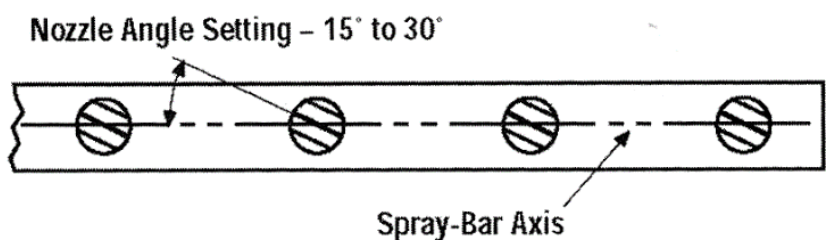

Figure 2-14 Proper nozzle angle setting (Asphalt Institute, 2010) 


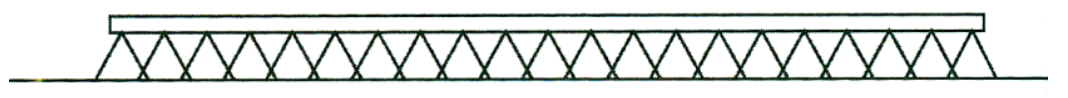

Incorrect Spray Bar Height

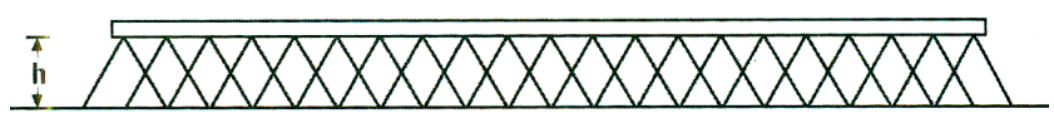

Correct Spray Bar Height - Double Coverage

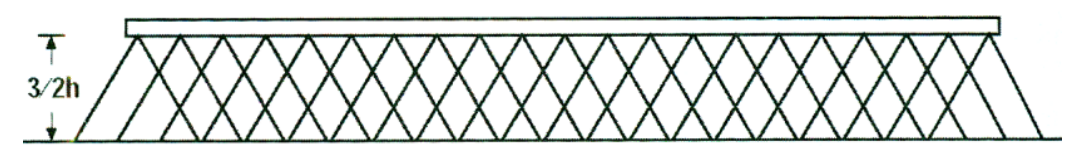

Correct Spray Bar Height - Triple Coverage

Figure 2-15 Correct spray bar hight (h=4 inches) (Asphalt Institute, 2010)

\section{HAULING AND TRANSPORTATION}

The second step in HMA construction is hauling or transportation, and it consists of every action and equipment required to transfer HMA from a plant to the paver or to the material transfer device, MTV, if one is used on the job. The steps in transporting include truck loading, weighing and ticketing, hauling to the paving site, dumping of the mix into the paver or MTV, and returning to the HMA plant (Roberts et al., 1996). The purpose of the hauling process is to provide a constant delivery of HMA material from the plant to the paving site. This must be done as prompt as possible and with minimal change in the characteristics of the mix.

\section{TRUCK TYPES}

There are two types of haul vehicle used to transport HMA from the plant to the paver in West Virginia: End dump and live-bottom. End dump truck (Figure 2-15) has a better maneuverability because it has no trailer and it is smaller than live bottom truck (Asphalt Institute, 2010). End dump truck has a short wheelbase with capacity of 12 to 20 tons and it is predominantly used in West Virginia. Live-bottom trucks (Figure 2-16) deliver the asphalt concrete by conveyor which minimizes segregation. 


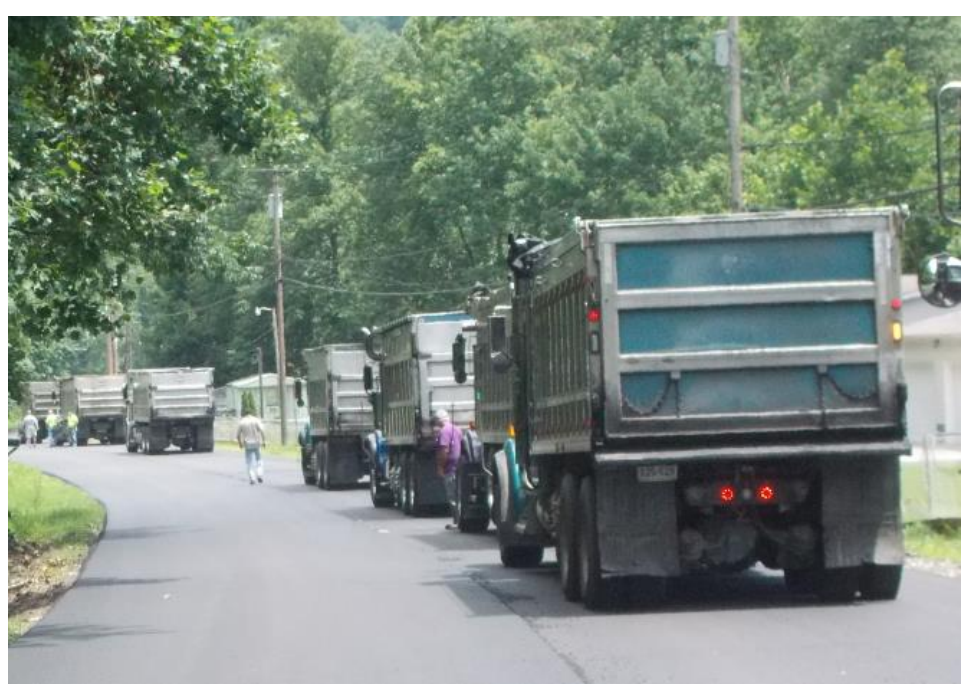

Figure 2-16 End dump trucks

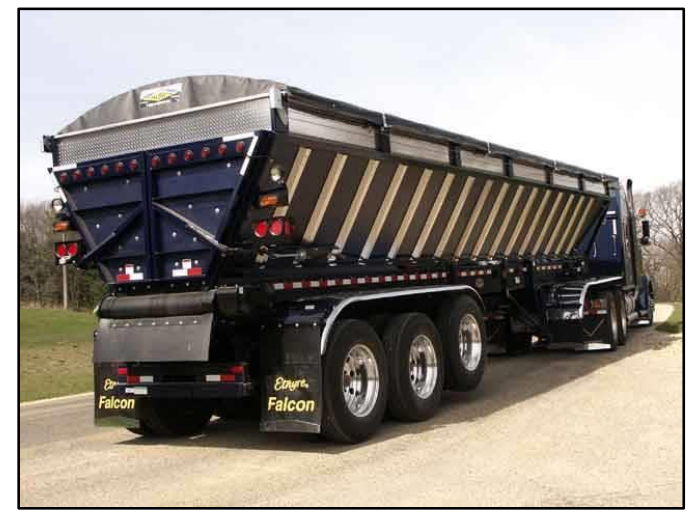

Figure 2-17 Live-bottom trucks (TRE)

\section{MECHANICAL CONDITION OF TRUCKS}

The hauling units should be mechanically sound. Mechanical problems may disturb consistent delivery of material. Furthermore, liquid leakage from the trucks on the paving site can be harmful to the HMA. Any problematic hauling unit should be removed from the job until the problem will be solved (Asphalt Institute, 2010).

\section{CLEANNESS OF THE TRUCK BED}

The truck bed must be free of all deleterious materials before being loaded with the mix. Any debris from previous use of the truck should be removed first. Since the asphalt material 
becomes sticky and hard to remove as it cools, the operator should clean the bed right after delivering the material to site (US Army COE, 2000).

\section{RELEASE AGENT}

Release agent should be applied to the areas of the truck bed which are in contact with HMAC to avoid the HMA from sticking to the bed. The amount of release agent used should be the minimum amount possible to uniformly cover the truck bed and side walls. Excess release agent in the form of run off should be drained before loading. Petroleum-based materials should not be used for this purpose. In addition, the bed surface should be reasonably smooth and free of holes or any major indents to prevent non-uniform coating of release agent on the surface (US Army COE, 2000, WVDOH, 2002).

\section{LOADING AT THE PLANT}

It is important to prevent mix from segregation when loading the truck. As shown in Figure 2-17, unless the free edges are blocked by the side walls, the larger aggregates will roll down the slopes and cause segregation in the material. The best practice to minimize the chance of segregation while hauling is to first load against the front and back ends of the truck and finally use the third load to fill in between the first two loads, Figure 2-18 (Skinner, 2005).
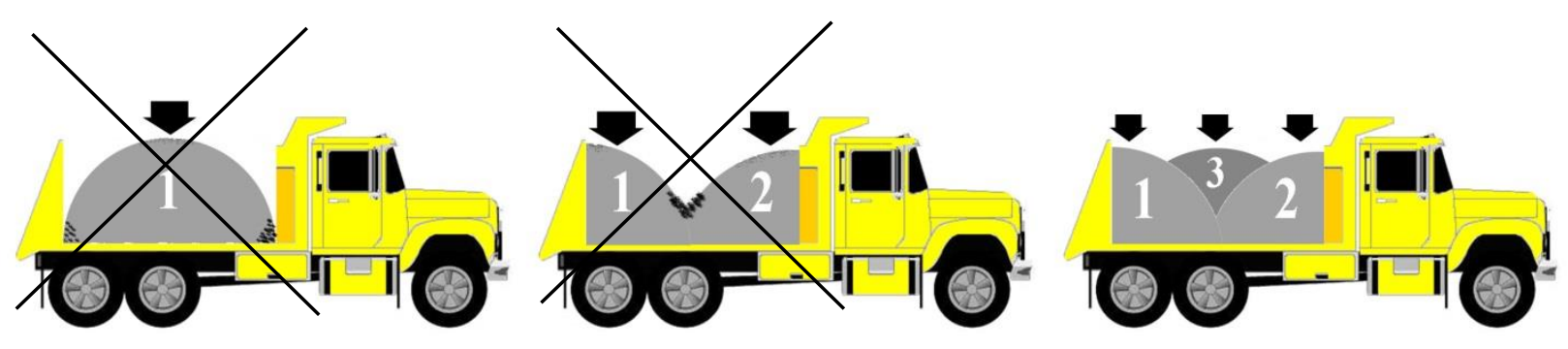

Figure 2-18 Loading sequence

In addition, all trucks should obtain load printouts including project number, number of axles, mix type and weight, time and date of loading (WVDOH, 2002). Once the truck is loaded, covered and the weight ticket has been collected the driver should leave immediately for the paving site. 


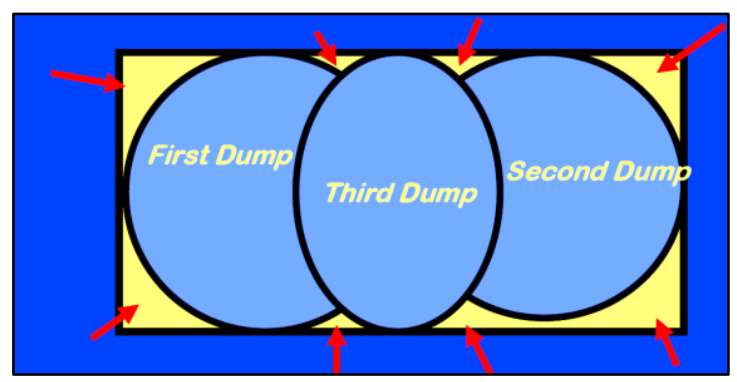

Figure 2-19 Best loading practice (Skinner 2005)

\section{MATERIAL TEMPERATURE IN THE TRUCK}

The asphalt concrete properties are highly dependent on the asphalt temperature. Therefore, all the HMA hauling units should have a small hole on their sides for measuring the asphalt temperature in the truck (WVDOH, 2002). Moreover, truck bed and walls should be insulated properly. Most importantly, tarp should be placed over truck bed to protect HMA against heat loss and rainfall Figure 2-19. It is recommended to select the possible closest HMA production facility (plant) to the paving site to minimize the heat loss during transportation (US Army COE, 2000 and Asphalt Institute, 2010).

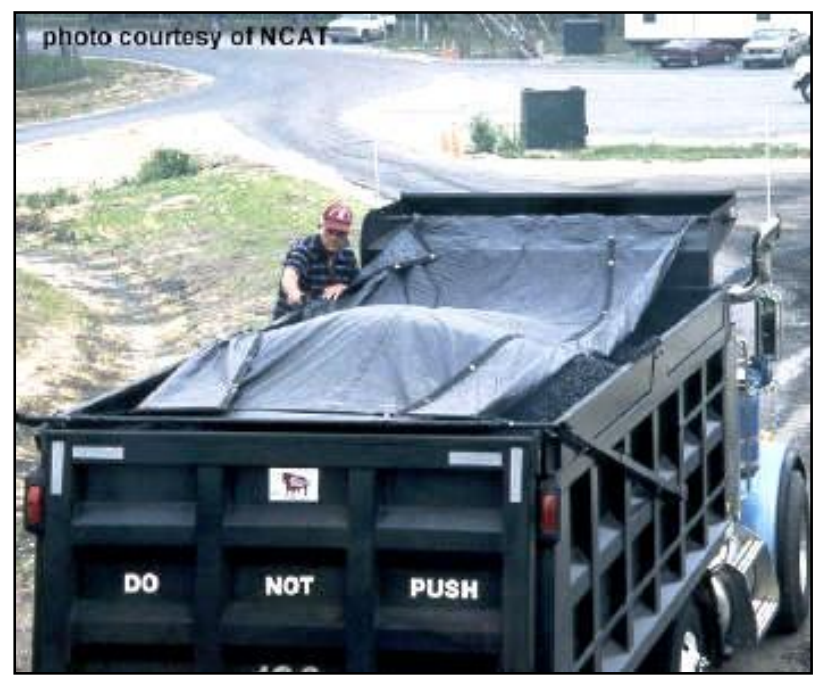

Figure 2-20 Tarp provides less heat loss (Pavement Interactive, 2014) 


\section{UNLOADING AT THE PAVING SITE}

HMA can be unloaded into the paver or MTV at the paving site. Here are the basic procedures and the best practices about unloading HMA at the paving site (Asphalt Institute, 2010, US Army, 2000, and WVDOH, 2002).

- HMA should be unloaded quickly when it arrives at the paving site to minimize mix heat loss.

- Before HMA is loaded into the paver, the inspector should check the mix in accordance with HMA design or job mix formula (JMF).

- If the HMA is being delivered by an end dump truck that dumps the mix directly into the paver hopper, the truck should stop just short of the paver. The paver should move forward and pick up the truck instead of the truck backing into the paver. When raised, the bed of the haul truck bed should not rest on any portion of the paver (Figure 2-20).

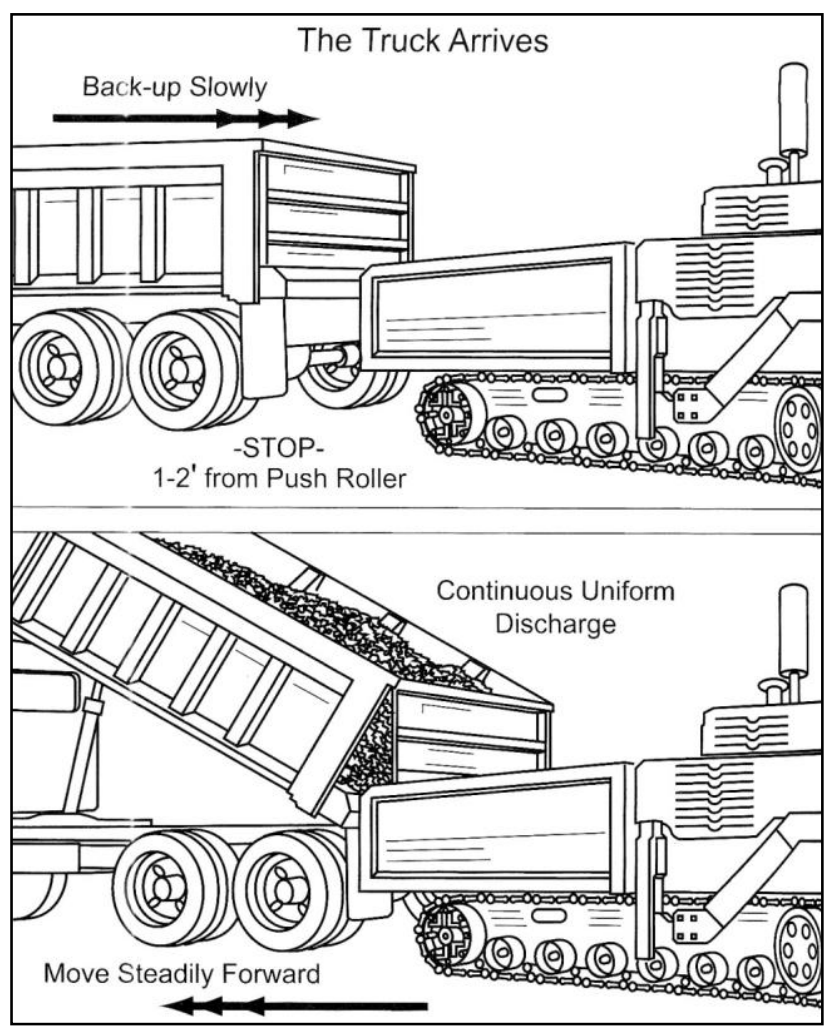

Figure 2-21 Proper loading of paver (Asphalt Institute, 2010) 
- The driver should "break" the load before unloading mat into hopper; before the truck tailgate is opened the truck bed should be lifted slightly while backing up to paver. The truck tailgate is opened when the mix in the bed moves against the tailgate and the MTV or paver is in position to accept the mix. This procedure allows the mix to flow steadily into the paver or MTV.

- After the load is discharged the bed should be lowered as the truck pulls away from the paver or MTV. The truck should go to a designated clean out area for removal of any material that was not discharged. Materials should not be dumped in front of the paver.

\section{HMA PLACEMENT}

HMA placement includes all activities and equipment used to place the delivered mix over the prepared surface at required thickness. This can include the use of a material transfer device as an interface between the haul trucks and paver. This is an optional piece of equipment that has the potential to offer several benefits.

\section{MATERIAL TRANSFER VEHICLE}

Material transfer vehicle (MTV) is used to transfer HMA material from the hauling unit to the paver Figure 2-21. This allows the paver and truck connection issues can be avoided. In addition, trucks can dump their loads in the MTV and leave the paving site immediately, which increases the hauling system efficiency. MTVs can come with or without remix capability. These MTVs provide an extra surge volume for continuous paving. The temperature and aggregate segregation can be decreased by using the MTV with remix capability (Lenz, 2011).

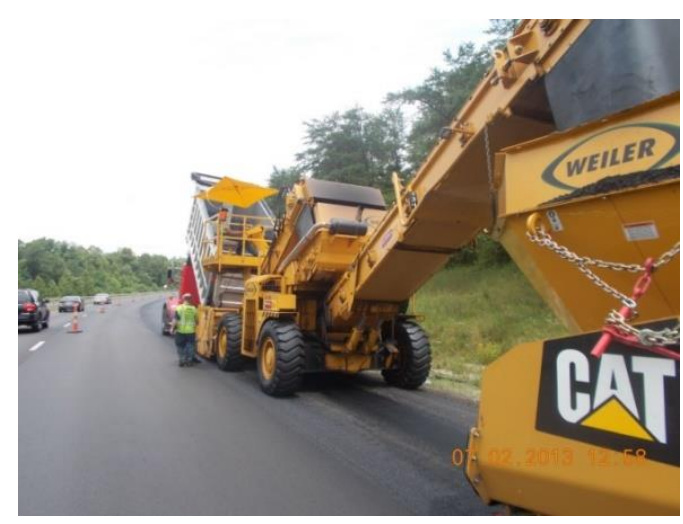

Figure 2-22 Material Transfer Vehicle without Remixing 


\section{THE ASPHALT PAVER}

Delivered mix is discharged into the paver hopper. Then the material is carried to the rear by slat conveyors, after that the HMA material is distributed laterally by a set of augers, and finally the mix leveled and partially compacted by a screed. Generally, there are two types of paver: tracked and wheeled paver Figure 2-22. Table 2-1 presents the advantages and disadvantages of tracked and wheeled pavers.

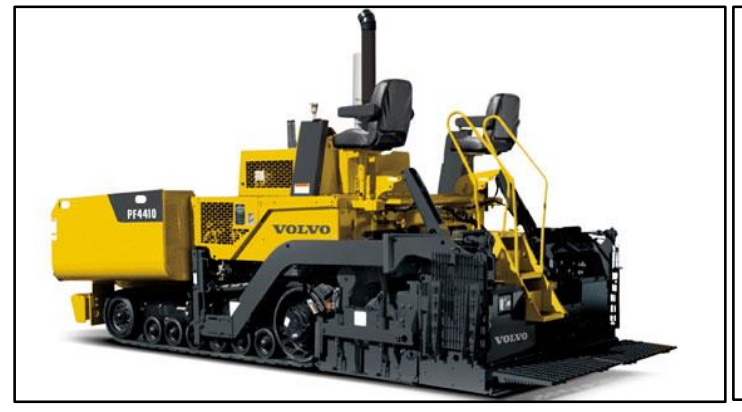

Tracked Paver

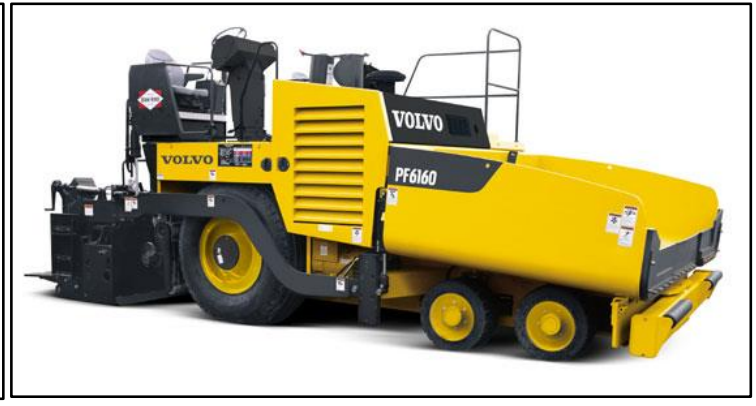

Wheeled Paver

Figure 2-23 Tracked and wheeled paver (Volvo Construction Equipment, 2014)

Table 2-1 Advantages and disadvantages among tracked and wheeled pavers (Sunkenberg, 2012)

\begin{tabular}{|l|l|}
\hline Tracked paver & Wheeled paver \\
\hline Advantages: & Advantages: \\
Excellent floatation & Mobility \\
Lower ground bearing pressure & On-Site Speed \\
Excellent traction & Maintenance Costs are Less \\
depths & Familiar Controls \\
$\begin{array}{l}\text { Flexible track allows acceptable on-site } \\
\text { speeds \& Ride comfort }\end{array}$ & \\
\hline $\begin{array}{l}\text { Disadvantages: } \\
\text { Less mobile, needs transporting } \\
\text { Higher initial purchase costs } \\
\text { higher Maintenance costs }\end{array}$ & \\
& Disadvantages: \\
& Center point wheel load. \\
& May spin on loose surfaces or heavy tack \\
& Risk of punctures, loss of air \\
\hline
\end{tabular}

Accordingly, the paver is made up of two main units: tractor and screed Figure 2-23. The primary functions of the tractor is pulling the screed, pushing the truck, providing a flow path for the material, providing the power to operate the paver and providing an operator's position. The primary function of the screed is laying material to accurate widths, depths and profiles, 
providing initial compaction to the mat, smoothness and seals the mat and controls material flow rate (Asphalt Institute, 2010). Material flow path through the paver is presented in Figure 2-24 (Sunkenberg, 2012).

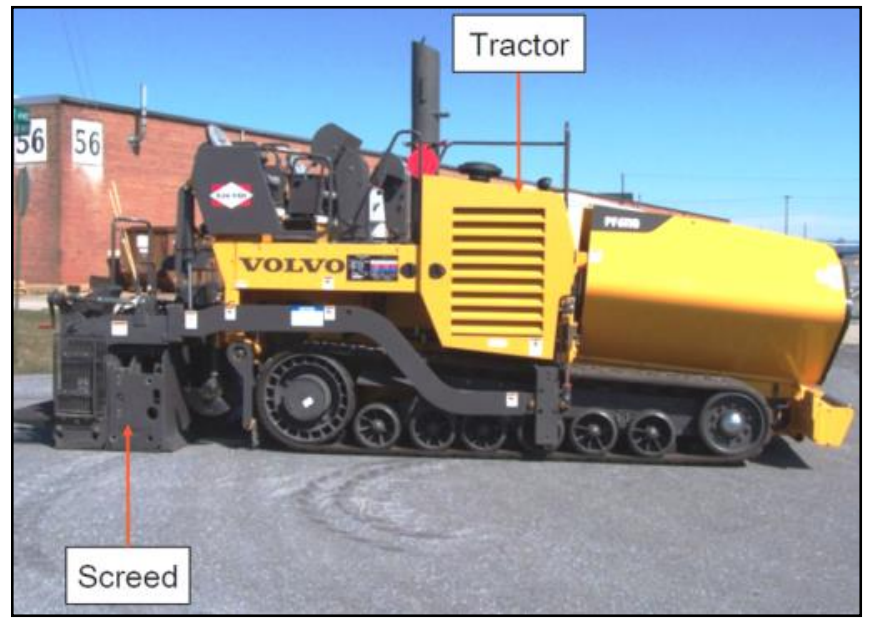

Figure 2-24 Tractor and screed in paver (Volvo Construction Equipment, 2014)

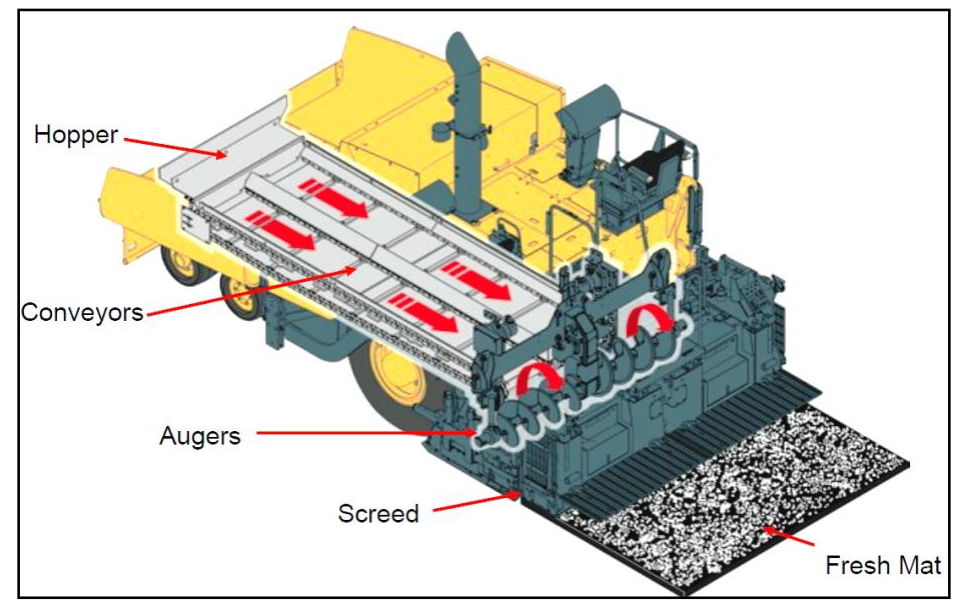

Figure 2-25 Material flow path through the paver (Sunkenberg 2012)

\section{Screed Heaters}

Screed plate temperature should be raised to the HMA temperature before beginning to pave. Otherwise the asphalt material will stick to the cold surface of the screed plates and result in defective surface behind the paver. To avoid this problem the screed is equipped with a heater 
which must be turned on before starting the job. It can be turned off shortly after beginning the job when the screed plate and HMA material have reached thermal equilibrium (US Army COE, 2000).

\section{Folding Wings}

The WVDOH Construction Manual states "Wings on the paver can be folded, as needed, to prevent cold mix from accumulating in the corners" of the hopper (WVDOH 2002). No guidance is given on the frequency of folding the hopper wings. The Hot Mix Asphalt Paving Handbook (US Army COE, 2000) addresses this issue in detail. The recommended procedure is to use fillets in the corners of the hopper to prevent the accumulation of material in the corners. If material can be prevented from accumulating in the corners, then there is no need for raising the hopper wings during the paving operation. The alternative to fitting fillets is to simply allow material to collect in the corners of the hopper. The material will cool forming a block that will prevent the further accumulation of material. After paving is complete for a shift, the wings are raised to force the material on to the slat conveyor. This material is then manually removed from the hopper and recycled at the plant or wasted. Although it is not a recommended practice, the Handbook does address folding the wings while the paving. The wings should be raised infrequently and only when there is sufficient material in the hopper such that the top of the flow gate is not visible. The preferred time for folding the wings is immediately after a truck finishes dumping a load into the paver. The wings should not be raised when the slat conveyors are visible.

\section{Hopper Level}

The level of asphalt concrete in the hopper should not drop below the bottom of the flow gates. In another words, the hopper level should be always above the point where slat conveyors are not visible. However, it should not be so full that asphalt spills out the hopper (US Army COE, 2000).

\section{Self-Leveling Screed and Angle of Attack}

Self-leveling screed is a standard feature for pavers. The paver screed is pulled into the HMA material deposited in front of it by the auger, and it automatically move up or down to adjust flat screed plate with the direction of pull in parallel. In addition, several forces act upon 
the screed to get to equilibrium, and result in paving a uniform lane thickness till the forces balance changes (Figure 2-25) (Asphalt Institute, 2010).

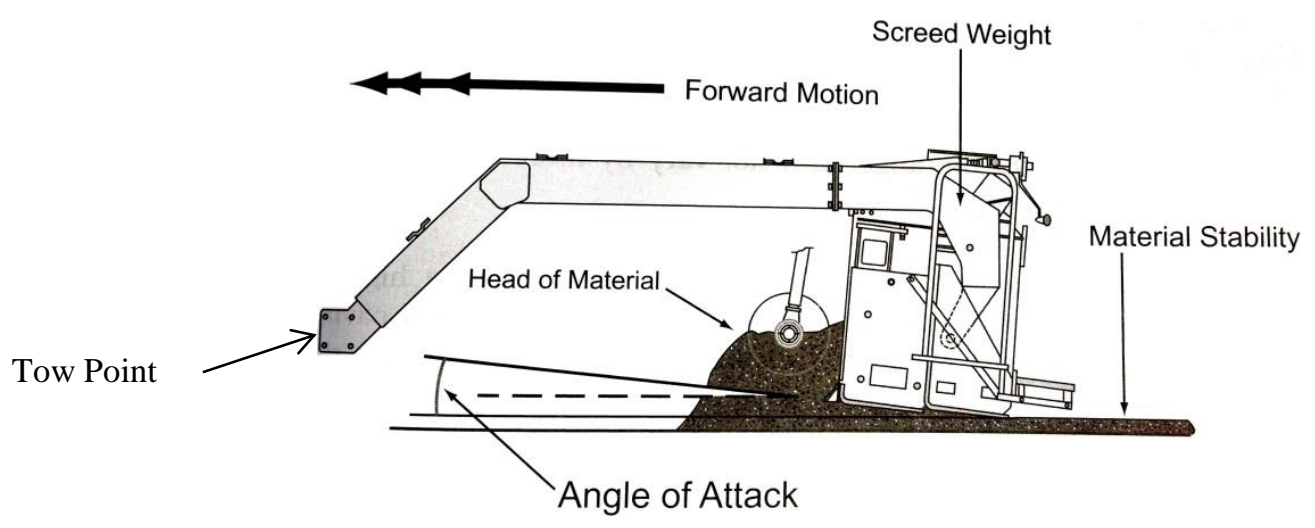

Figure 2-26 Self-leveling screed and forces (Asphalt Institute, 2010)

As shown in Figure 2-25 the angle of attack is the angle between screed and paving grade. This angle can be adjusted by raising or lowering the screed tow point. In addition, by increasing the angle of attack more material flow under the screed, and result in raising the screed to gain balance with other forces that act upon the screed (Asphalt Institute, 2010).

\section{Effect of Screed on Mat Texture}

Screed should be extended properly, and angle of attack should be adjusted correctly. Sometimes extended screed may cause difference in surface texture due to a mismatch in elevation between the two screeds (US Army COE, 2000). Any cold chunk of asphalt should be avoided to get under the screed. It can affect the mat texture. It is important that the source of the chunks identified and removed (Asphalt Institute, 2010).

\section{Material Head at the Auger}

Any changes in the material head in the auger will lead to change in thickness of the layer being paved. Therefore, it is important to maintain a constant head of material in front of augers. Moreover, overloading the auger can cause segregation and very low material level in this area can result in material shortcoming on the paving sides. The level of material in auger should be at the middle level as seen in Figure 2-26 (US Army COE, 2000). 


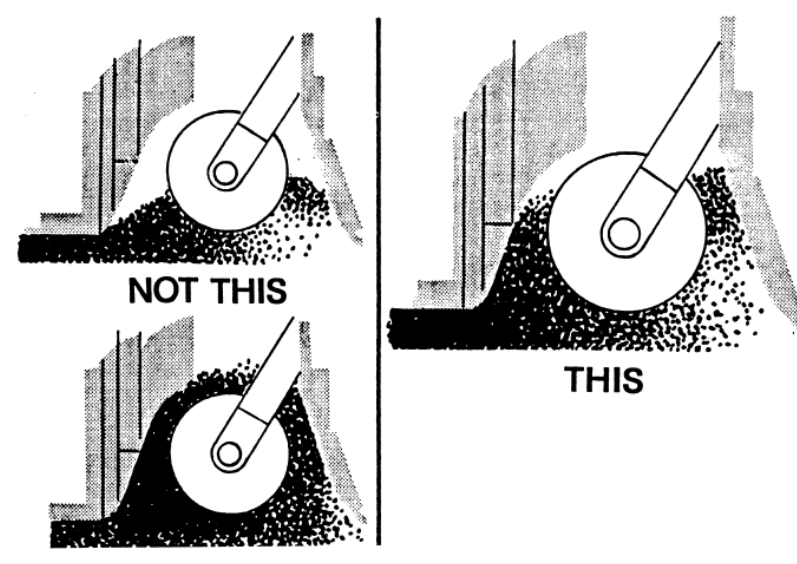

Figure 2-27 Correct and incorrect mix levels in paver auger chamber (US Army COE, 2000)

\section{Paver Speed}

Whenever all the asphalt concrete is discharged into the hopper, the paver speed should be increased and maintain a constant speed appropriate to the amount of mix being delivered from the trucks (US Army COE, 2000). In addition, paver should never stop because each stop may cause "bump" on the pavement (WVDOH, 2002).

\section{Automatic Grade and Slope Control Device}

Paver can be equipped with an automatic grade and slope control device that can automatically maintain the desired screed elevation and transverse slope. If Automatic controls fail to obtain the specified surface, the contractor can continue with manual controls for entire job (WVDOH, 2002).

\section{TRANSVERSE JOINT}

Normally there are two types of transverse joint; the new section starts at the end of an old paved section, transverse joint was left at the end of last working shift. For the first transverse joint the surface should be cut or milled to create a straight and clear cut edge to start the paving. The material from the joint should be removed; the surface needs to be cleaned and in addition to the surface all the clear edges should be uniformly tacked. In the second one where a temporary transverse joint occurs at the end of the paving shift there are two popular options to reduce the labor work to prepare the joint to start over (US Army COE, 2000, Asphalt Institute, 2010). 


\section{Butt Joints}

A butt joint can be used when traffic will not be passing over the joint. The joint location is selected; the upstream side will remain un-touched. The downstream side is raked away, and boards are laid lengthwise to allow the roller to compact the edge without rolling it over. As illustrated in Figure 2-27 butt joints, this style places a board at the end of the mat, and then builds a small ramp for getting equipment off of the mat (US Army COE, 2000).

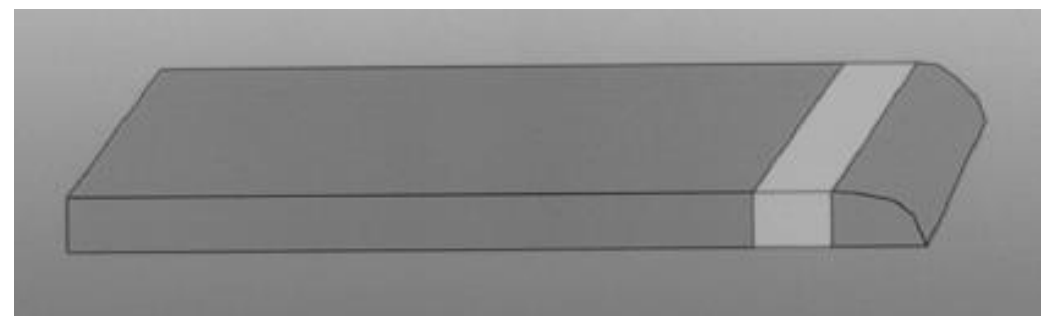

Figure 2-28 Butt joint (US Army COE, 2000)

\section{Tapered Joint with Paper}

Treated release paper or similar fabric which does not stick to the asphalt is placed downstream of the joint. Mix is shoveled onto the paper, formed into a ramp, and then the mat and the transition are compacted. This way removing the material from the joint will be much easier (US Army COE, 2000).

\section{PAVING EDGES}

A paver making two passes to cover a two lane road will produce both "supported" and "unsupported" edges. The first pass of the paver is frequently called the cold pass because material placed with this pass will cool before the adjacent lane is paved. The second pass is called the hot pass because the hot material is placed next to the cold material.

At the outside edges, where there is either gravel or earth next to the pavement, the FHWA is promoting the use of the "safety edge" to assist drivers in transitioning back onto the paved surface in the event that they drift off the pavement (FHWA, 2014). On the edge between the cold and hot passes is a longitudinal joint. Due to the challenge of obtaining density at the longitudinal joint it is frequently the location of premature pavement distress. Some agencies are 
using wedge joints on the inside edge of the cold pass in an attempt to improve pavement performance.

\section{Unsupported Edges}

Unsupported edges are produced when the paver places material on top of an existing surface. Both of the edges from this pass are unsupported. Paver should run in a straight line, and a string line or "skip line" paint marks are recommended to assist the paver operator to pave in a straight line (WVDOH, 2002).

\section{Wedge Joints}

Sometimes the traffic is allowed next to the cold (first) lane before hot (second) lane is constructed and the agencies restrict the compacted depth of HMA that can be placed. In this situation a wedge joint may be used. A wedge joint (Figure 2-28) can be formed by attaching a metal to the end gate of the paver screed for the construction of the first lane (US Army COE, 2000).

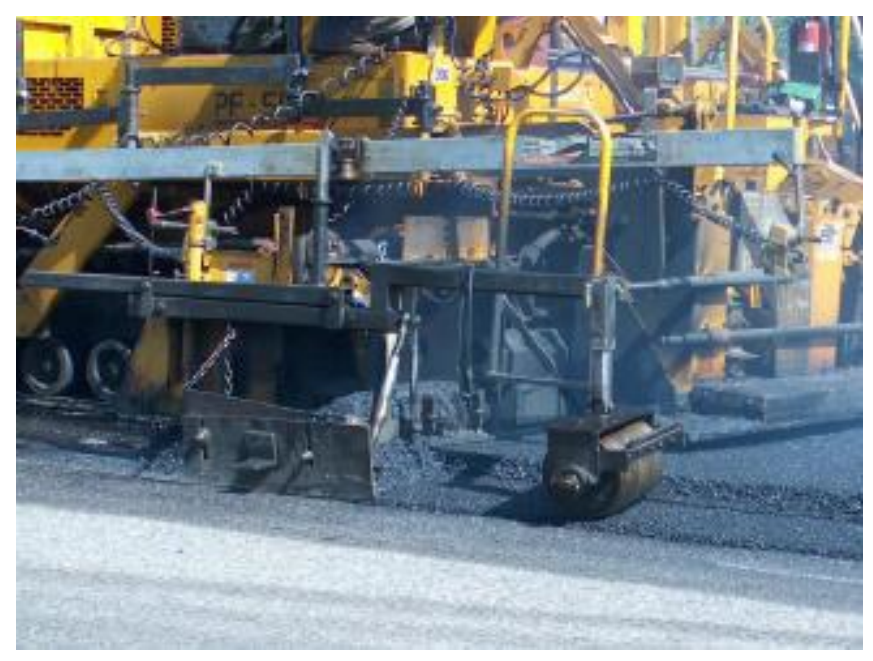

Figure 2-29 Wedge Joint (Pavement Interactive)

\section{Safety Edge}

A safety edge is a wedge placed at the outside edge of pavement $\left(30-35^{\circ}\right)$ that allows vehicle that has wandered off the paved surface to return to the pavement in a controlled manner. This requires attaching a special Safety edge reduces vehicles accidents due to their roadway cross departure. An extension is added to the paver screed to form the angled safety edge as 
shown in Figure 2-29 (INDOT, 2008). Research has demonstrated the safety edge is a cost effective method of reducing accidents (Graham et al., 2011).

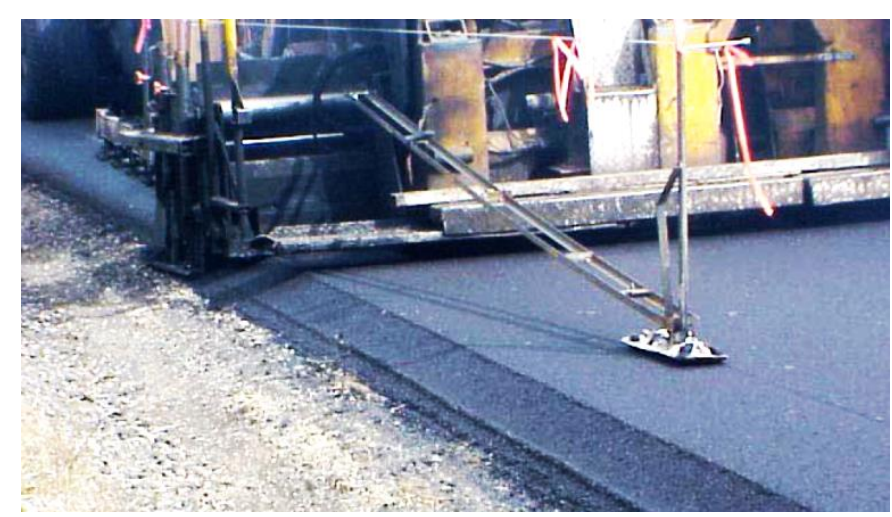

Figure 2-30 Safety Edge (INDOT, 2008)

\section{Supported Edge (Longitudinal Joint)}

A supported edge is produced when the paver is placing material next to the material from the previous pass (first pass). A supported edge can also be formed when the lane being paved has been milled and the adjacent lane has not been milled. A longitudinal joint is formed at the interface of an unsupported edge and a supported edge. As shown in Figure 2-30, the material at longitudinal joint should overlap the adjacent material 1 to 1.5 inches (US Army COE, 2000).
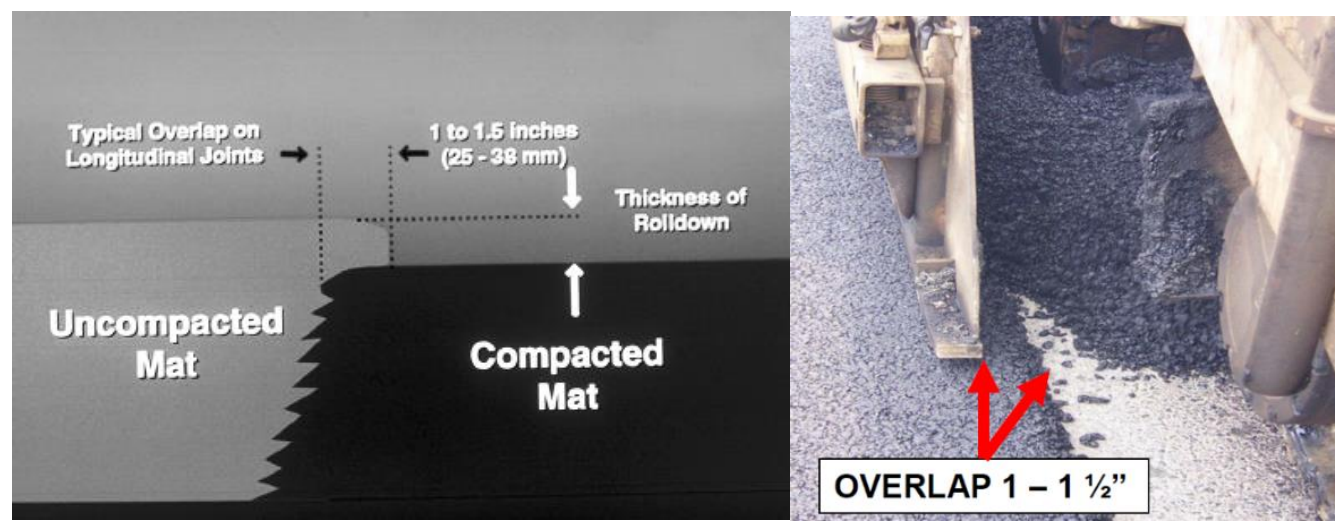

Figure 2-31 Overlapped joints (Us Army COE, 2000) 


\section{LUTING}

Luting is required for irregular pavement shapes. However, luting at joints should be minimized (Asphalt Institute, 2010). If luting at the joint is required the material should be just push back and accumulate on the top of the joint. Sufficient care must be applied to avoid moving material past the joint and it should never be cast across the mat (US Army COE, 2000).

\section{COMPACTION}

The following guidelines should be noticed to achieve a uniform pavement density and a smooth riding.

\section{TEMPERATURE AND THICKNESS CONSIDERATIONS}

The available time for compaction operation is primarily affected by the temperature and the thickness of the new placed HMA layer. An increase in lift thickness results in increase the available time for the rolling process. Temperature also affects mix stiffness and workability. Proper temperature provides enough time for rollers to apply sufficient passes over paved layer. West Virginia Division of Highways (DOH) construction manual suggests that the required density must be obtained prior to the mat temperature getting $175^{\circ} \mathrm{F}\left(80^{\circ} \mathrm{C}\right)(\mathrm{WVDOH}, 2002)$.

\section{MECHANICAL CONDITION OF ROLLERS}

Rollers should be checked prior the job is started. Hydraulic and motor oil are harmful to asphalt concrete, and leaks should be fixed before the roller gets on the hot mat. Both water and fuel tanks should be filled before the job starts (Asphalt Institute, 2010).

\section{WATER SPRINKLE AND SCRAPERS}

To avoid asphalt concrete from sticking to the drum surface the drum should be kept moist. The scrapers should be sound and be in touch with the drum surface to scrape asphalt concrete off the drum. Asphalt concrete stuck to the drum will result in poor finished surface texture (Bomag, 2009).

\section{ROLLER PATTERN AND COMPACTION OF HMA}

WV DOH suggests construct the test section to determine the most efficient roller patterns. It should be prevented to make more necessitate roller passes to satisfy density requirements. In addition, after a roller pattern has been determined, the roller pattern should not be changed for 
the same mix and the lift thickness (WVDOH, 2002). Additionally, it is highly important that the operator stick to the established roller pattern and make sure that the entire mat surface is rolled equally. The definition of pass and coverage were defined by asphalt institute as below (Asphalt Institute, 2010):

"Pass is defined as the roller passing over one point in the mat one time. Coverage is defined as the roller making enough passes to cover the complete width of the mat being placed."

Figure 2-31 presents 5 passes that provide 2 complete coverages for one paved lane. The rolling pattern should include the number of passes, the location of first pass, the sequence of succeeding passes and the overlapping between passes.

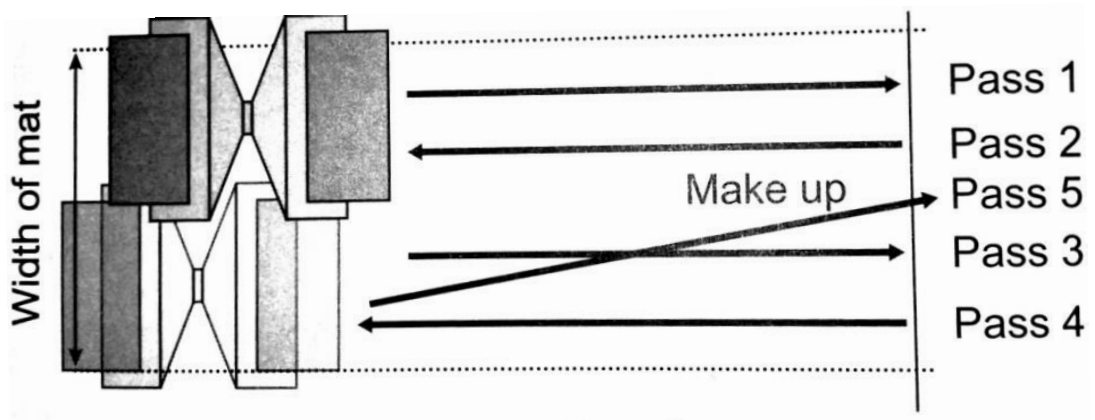

This is a 5 pass pattern that provides 2 complete coverages.

Figure 2-32 Pass and Coverage for a paved lane (Asphalt Institute, 2010)

Compaction process should be conducted in 6 rolling procedures (WVDOH, 2002):

1- Transverse joints,

2- Longitudinal joints,

3- Edges,

4- Initial or breakdown rolling,

5- Secondary or Intermediate rolling,

6- Finish rolling.

Initial or breakdown rollers compact the material after distribution of HMA mix by the paver, then intermediate rolling compacts and seals the surface, and finally the rollers marks and other spots left from the previous rolling are removed by finish rolling. As a result, the surface 
texture will be improved and ready for traffic. The rolling pattern for intermediate rolling is the same as the pattern for breakdown rolling.

It is recommended to start the rolling process on the low side of the paved area which is the outside of the paved lane, and continue toward the high side. It is because the hot mix tends to migrate to the low side during rolling operation, and if the roller operation starts on the high side this mitigation will be increased toward low side (Asphalt Institute, 2010).

\section{TRANSVERSE JOINT COMPACTION}

Transverse joints should be compacted perpendicular to the paving direction if possible. In other words, roller should be operated across the width of the lane, and this practice can be difficult occasionally due to safety restrictions Figure 2-32-A. Therefore, the transverse joint is typically rolled in the longitudinal direction Figure 2-32-B (US Army COE, 2000).

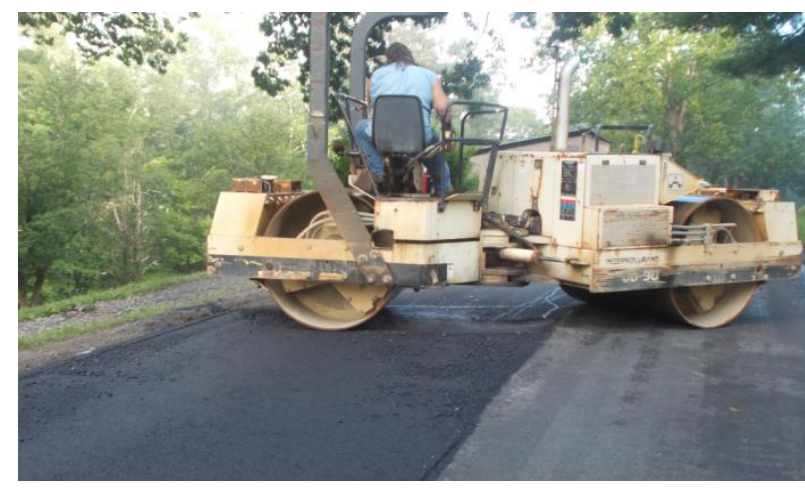

A) Perpendicular to the paving direction

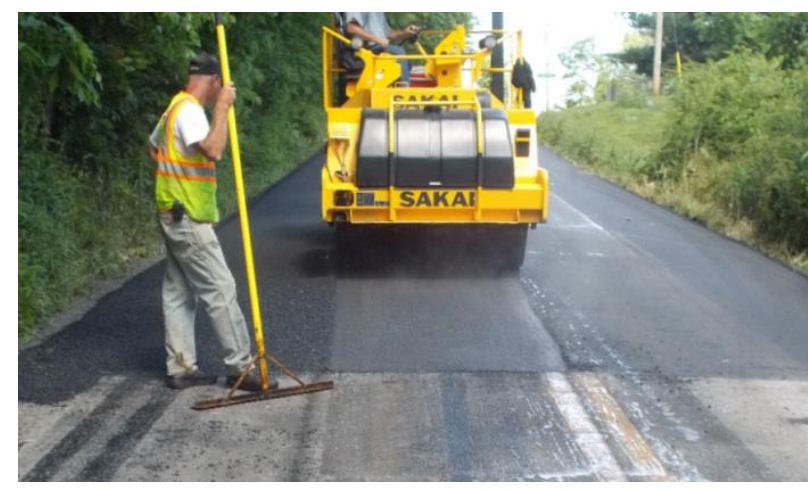

B) Parallel to the paving direction

Figure 2-33 Transverse joint compaction

\section{UNSUPPORTED EDGE COMPACTION}

The drum should be extended over the unsupported edge of the lane by approximately 6 in (150 mm) (US Army COE, 2000). As shown in Figure 2-33 the roller drum should not run inside the unsupported edge because the mix tends to extend out. It is also the roller drum should not run directly over the unsupported edge. 


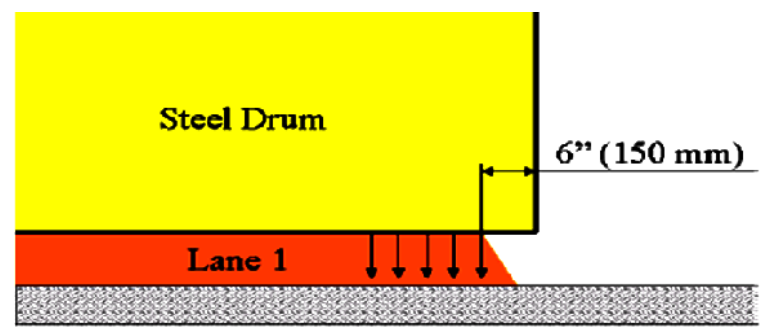

A) Good Practice

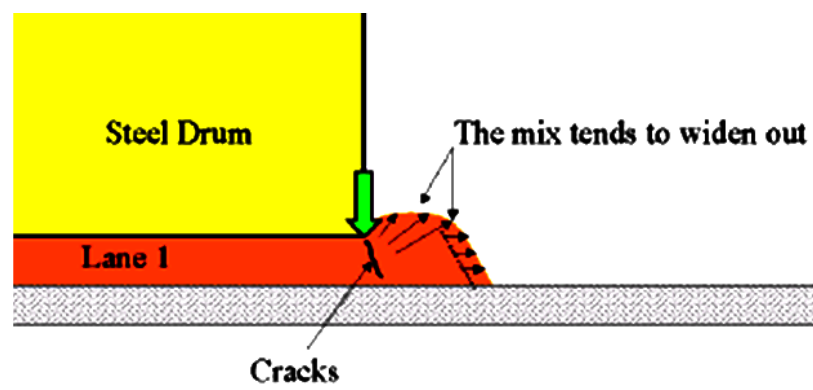

B) Bad Practice

Figure 2-34 Unsupported edge compaction (WVDOH, 2013)

\section{SUPPPORTED EDGE COMPACTION}

For longitudinal joints compaction, as shown in Figure 2-34, the roller drum should be held about 6 inches away from the joint on the first pass. This results in a thin strip of uncompacted mat. By way of the roller reverse direction, the roller drum should be moved over this left thin strip and overlap 6 inches on the cold mat Figure 2-35. This is the most efficient way to compact a longitudinal joint that the majority of the roller drum is placed on the hot (new) lane. In this way the majority of the compaction energy is applied where it is most needed (Asphalt Handbook, 2010).

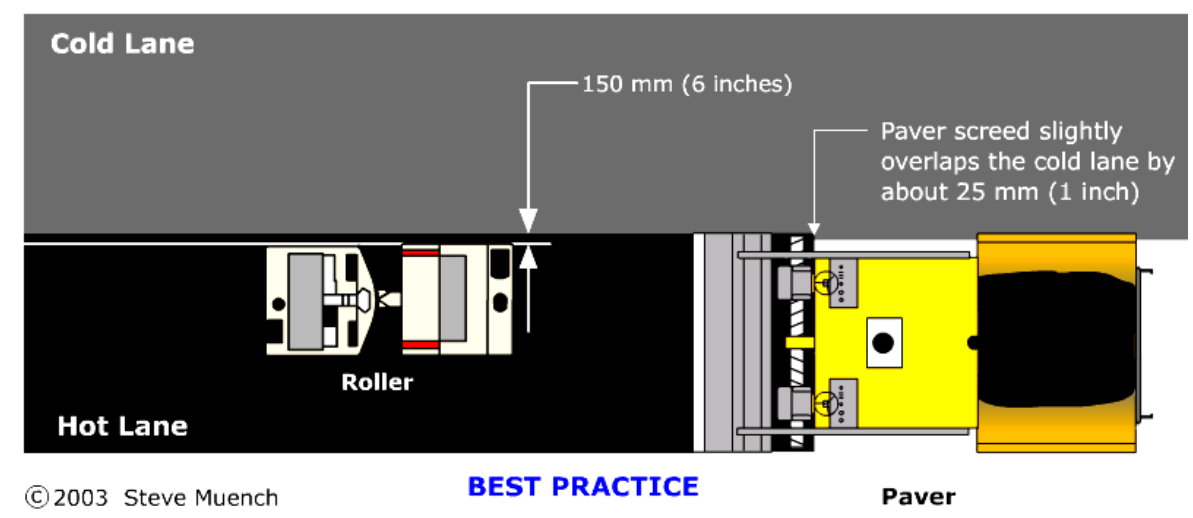

Figure 2-35 Longitudinal joints compaction (Pavement Interactive, 2014) 


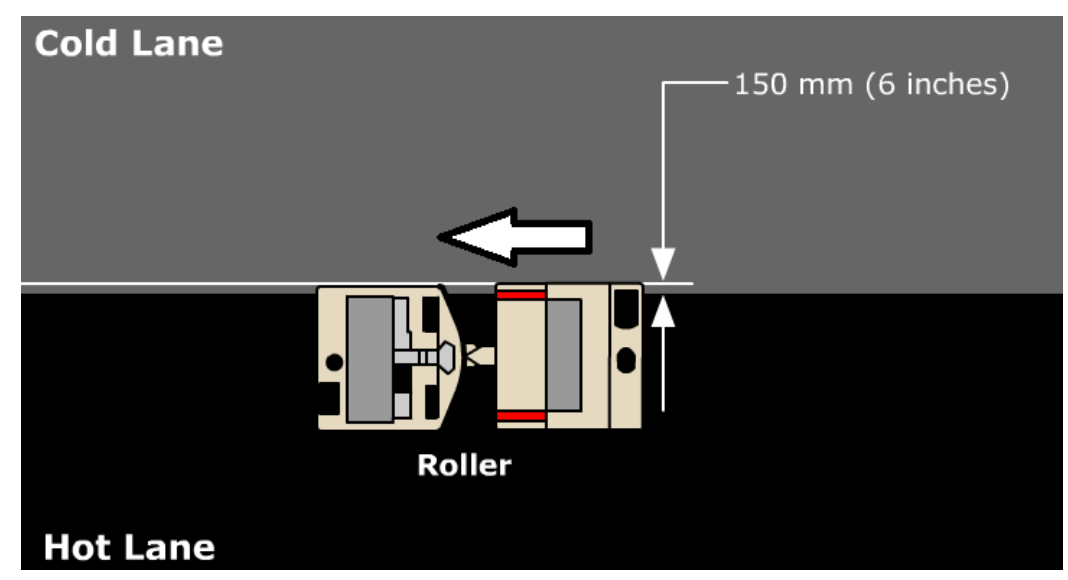

Figure 2-36 Longitudinal joints compaction, picture modified (Pavement Interactive, 2014)

\section{ROLLER SPEED AND IMPACT}

Rollers should operate at a slow and uniform speed to avoid shoving the HMA mix. The maximum speed for static and vibrator rollers should be $2.5 \mathrm{miles} / \mathrm{hr}(4.0 \mathrm{~km} / \mathrm{hr})$ and $3 \mathrm{miles} / \mathrm{hr}$ $(4.8 \mathrm{~km} / \mathrm{hr}$ ) respectively (WVDOH, 2002). In addition, sharp turns and quick starts or stops on the hot mat should be avoided.

The roller drum vibrates while moving, and it can create small impacts in a uniform pattern. These uniform impacts are visible, and a vibratory roller can usually produce 10-14 impacts per foot (33-46 impacts per meter) (Asphalt Handbook, 2010). 


\section{CHAPTER 3 RESEARCH METHODOLOGY}

\section{INTRODUCTION}

The WVDOH hired 4 co-ops during summer 2012 and 2 co-ops during summer 2013 to document asphalt pavement construction projects. The co-ops were assigned to observe and record pavement construction practices. Observations were documented on forms with supporting photographs. In the 2013 summer, GPS units and video cameras were used to monitor some of the construction activities. All 6 coops were trained and monitored by West Virginia University researchers. The training included a review of the WV DOH field technicians training manual and other references, procedures for completing the data collection forms, and field visits to paving projects and asphalt plants. The co-ops sent their daily observation to WVU for data recording and analysis. All the observations data were put into and analyzed using a Microsoft Access database. During the data collection period the WVU research staff monitored the data collection and provided feedback as necessary.

\section{DATA COLLECTION}

Prior to the summer of 2012, the WVU researchers prepared detailed data collection forms, appendix A. Upon initial data collection, it was found the forms were two cumbersome for use in the field. Based on feedback from the co-ops an "Excel-form" data collection process was developed. The original data collection forms were modified to become checklist that also provided an index of activity type, a description of the observation, and an identifier to associate any photographs with the process being observed.

The evaluation of the 2012 data raised a concern that there was a bias in the data collection toward documenting poor practices while ignoring good practices. To overcome this problem, randomization was used in the 2013 data collection. For example, a random time was selected for observing, the truck-paver interface. The co-ops then observed and documented a fixed

number of interactions between the truck and paver. After these observations were recorded, the co-ops moved to another activity. 
The co-ops transferred their observations, pictures and video files to computer cloud server on a daily basis. The WVU research staff downloaded the records from the cloud server, reviewed the records, provided feedback to the co-ops as needed, and stored the information on a local hard-drive. The records were then placed in an Access database.

\section{DATA STORAGE AND MANAGEMENT}

The Microsoft Access database management software was selected for the project as it has the needed features, in relatively easily to use and is widely available. Information in the Access database is stored in folders. Forms can be associated with each table to facilitate data entry and editing. The information is accessed with quarries. The result of the quarries can be used to produce reports or exported to excel for analysis. The Access procedures used for this research are documented in Appendix B.

The use of database files in Access is limited to 2 gigabytes and over 22 gigabytes of information was assembled during the project. A "front-end back-end" strategy was used to allow working with to the entire data net within the memory limitations of Access.

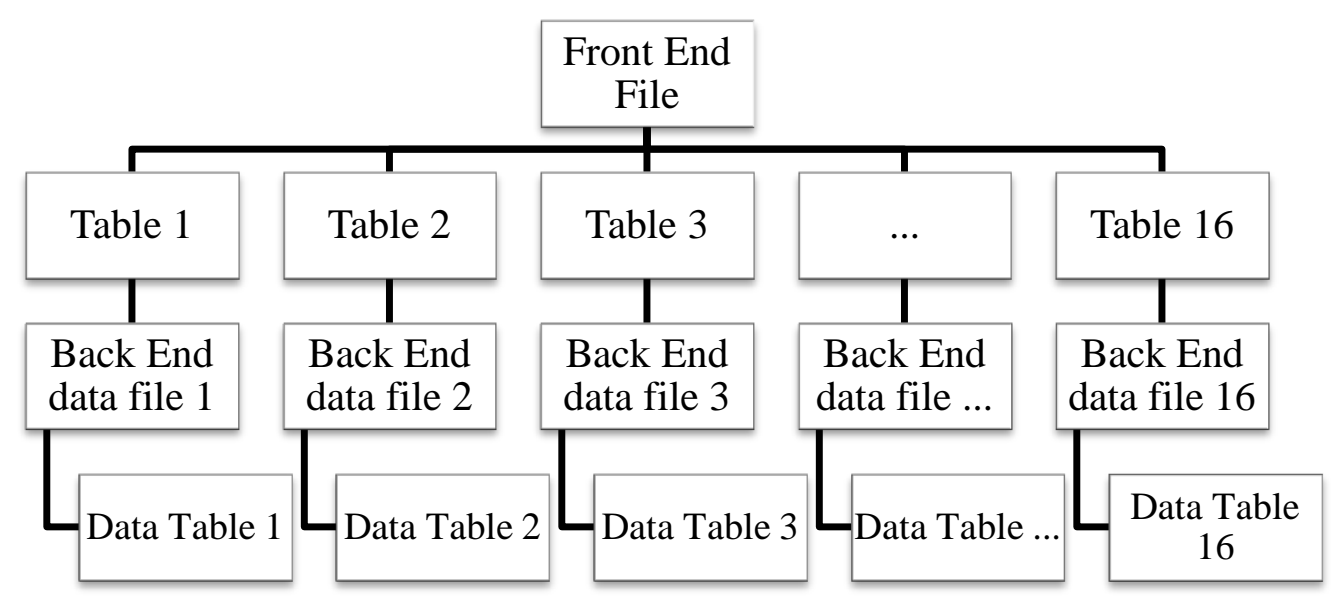

Figure 3-1 Data file and table structure

As shown on Figure 3-1, the main or central Access data file was set up with a series of tables. Each of these tables was associated with a back-end file which was intern associated with 
a single data table where the information was actually stored. The back-end files and associated tables were limited to 2 gigabyte. However, data files and associated tables could be added to the structure of the front-end file allowing an aggregated database whose size was only limited by the storage medium. This structure allowed query statements to look across all data tables to select the required information.

Table 3-1 is a summary of the structure of the front-end file and the type of information associated with each data table.

Table 3-1 Summary and description of the front-end file (data tables)

\begin{tabular}{|l|l|c|}
\hline Table Title & Description & $\begin{array}{c}\text { Number of } \\
\text { Access } \\
\text { Tables }\end{array}$ \\
\hline General & $\begin{array}{l}\text { Information about the jobs, such as the project number, project } \\
\text { type, location, etc. }\end{array}$ & 1 \\
\hline Plant & $\begin{array}{l}\text { Observation about HMA plant operation and condition } \\
\text { including stockpile condition, conveyor, cold bins, etc. }\end{array}$ & 1 \\
\hline Hauling & $\begin{array}{l}\text { Observation about truck condition and operation. It includes } \\
\text { truck bed clean, release agent used, loading sequence, etc. }\end{array}$ & 1 \\
\hline $\begin{array}{l}\text { Surface } \\
\text { Preparation }\end{array}$ & $\begin{array}{l}\text { Observation about surface condition prior to paving such as } \\
\text { clean surface, dry surface, tack coat uniformity, etc. }\end{array}$ & 1 \\
\hline Placement & $\begin{array}{l}\text { Observation about placing HMA, and it includes tack coat } \\
\text { uniformity, tack coat break, material delivery, screed set up, } \\
\text { load break, truck and paver connection, hopper overflow, } \\
\text { material distribution across the screed, hopper wings, } \\
\text { thickness checked, cross slope checked, etc. }\end{array}$ & 8 \\
\hline Compaction & $\begin{array}{l}\text { Observation about HMA compaction, and it includes stopping } \\
\text { on hot mat, visible defects at the end, transverse and } \\
\text { longitudinal joint compaction, etc. }\end{array}$ & 2 \\
\hline $\begin{array}{l}\text { Shoulder } \\
\text { Widening }\end{array}$ & $\begin{array}{l}\text { Observation about shoulder widening construction practices } \\
\text { such as trench condition, pavement edge, etc. }\end{array}$ & 1 \\
\hline $\begin{array}{l}\text { Temperature } \\
\text { Records }\end{array}$ & $\begin{array}{l}\text { The temperature of placed HMA was recorded at three times; } \\
\text { after placement by the paver, before compaction started, and } \\
\text { after compaction was completed. }\end{array}$ & 1 \\
\hline Trucks & Truck travel time from plant to job site & 1 \\
\hline
\end{tabular}

\section{DATA ANALYSIS METHODOLOGY}

All the data were collected and organized in an Access database for review and analysis in following general categories: 
1. Plants

2. Surface preparation

3. Hauling

4. Placement

5. Compaction

6. Shoulder widening

7. Truck travel time

8. Temperature drop

The first step in data analysis was done by co-ops in the field as they observed and recorded data using the provided forms, Appendix A. They transmitted the observations, along with or without pictures and video files, to a cloud server. The second step in data analysis was done by data loggers who retrieved the data and placed it into the Access database. Then the data were evaluated and rated by data loggers.

\section{PLANT}

Plants were inspected in several categories. Each category was analyzed base on descriptive phrases. All the plant inspected categories and related phrases are presented in Table 3-2 along with the best practice. Figures representing the ranking process follow Table 3-2. Some additional items that were observed on an infrequent basis include:

* Asphalt temp in the tanker

* Asphalt temp in the tank

* Asphalt cement heating

* Number of cold bin

* Aggregate sizes

* Frequency of moisture check 
Table 3-2 Phrase description and recommended practice for plant inspection categories

\begin{tabular}{|c|c|c|c|c|}
\hline & Phrase & Description of Phrase & Recommended practice & Figure \\
\hline \multicolumn{5}{|l|}{ Plant } \\
\hline $\begin{array}{l}\text { Stockpile } \\
\text { segregation }\end{array}$ & Yes/No & $\begin{array}{l}\text { "Yes" indicates aggregate segregation was observed in stockpiles. } \\
\text { "No" indicates aggregate segregation was not observed in stockpiles. }\end{array}$ & Minimized stockpile segregation & \\
\hline $\begin{array}{l}\text { Stockpile } \\
\text { separation } \\
\text { condition }\end{array}$ & $\begin{array}{l}\text { Good/Fair/ } \\
\text { Poor }\end{array}$ & $\begin{array}{l}\text { "Good" -adequate space between stockpiles. "Poor" - inadequate space } \\
\text { between stockpiles. "Fair" is situation between these two conditions. }\end{array}$ & $\begin{array}{l}\text { There should be a physical barrier or } \\
\text { adequate distance between stockpiles. }\end{array}$ & Figure $3-2$ \\
\hline $\begin{array}{l}\text { Stockpile } \\
\text { contamination }\end{array}$ & Yes/No & $\begin{array}{l}\text { "Yes" indicates stockpile was contaminated. } \\
\text { "No" indicates stockpile was not contaminated. }\end{array}$ & $\begin{array}{l}\text { Stockpile contamination should be } \\
\text { prevented. }\end{array}$ & \\
\hline $\begin{array}{l}\text { Stockpile base } \\
\text { condition }\end{array}$ & $\begin{array}{l}\text { Good/Fair/ } \\
\text { Poor }\end{array}$ & $\begin{array}{l}\text { "Good" indicate proper base condition (dry and clean) for stockpiles. "Poor" } \\
\text { indicate inappropriate base condition for stockpiles. "Fair" is situation } \\
\text { between these two conditions. }\end{array}$ & $\begin{array}{l}\text { Stockpile should be built on dry, clean and } \\
\text { stable surface. }\end{array}$ & Figure $3-3$ \\
\hline $\begin{array}{l}\text { Asphalt storage } \\
\text { type }\end{array}$ & $\begin{array}{l}\text { Horizontal/ } \\
\text { Vertical }\end{array}$ & & Vertical preferred & \\
\hline $\begin{array}{l}\text { Binder type } \\
\text { identified on the } \\
\text { tank }\end{array}$ & Yes/No & $\begin{array}{l}\text { "Yes" indicates binder type is identified on the tank. } \\
\text { "No" indicates binder type is not identified on the tank. }\end{array}$ & $\begin{array}{l}\text { Binder type should be identified on the } \\
\text { tank. }\end{array}$ & \\
\hline $\begin{array}{l}\text { Type of asphalt } \\
\text { binders }\end{array}$ & $\begin{array}{l}64-22,70-22 \\
, 76-22\end{array}$ & Binder grades in storage tanks & & \\
\hline $\begin{array}{l}\text { Tanks equipped } \\
\text { with mixer }\end{array}$ & Yes/No & $\begin{array}{l}\text { "Yes" indicates tanks are equipped with mixer } \\
\text { "No" indicates tanks are not equipped with mixer. }\end{array}$ & $\begin{array}{l}\text { Tanks should be equipped with mixer when } \\
\text { there is polymer modified asphalt in the } \\
\text { tank. }\end{array}$ & \\
\hline Insulation & Yes/No & $\begin{array}{l}\text { "Yes" indicates tanks have a proper insulation. } \\
\text { "No" indicates tanks do not have a proper insulation. }\end{array}$ & $\begin{array}{l}\text { The asphalt storage tank should be } \\
\text { insulated properly. }\end{array}$ & \\
\hline Vertical dividers & Yes/No & $\begin{array}{l}\text { "Yes" indicates cold bins have vertical dividers. } \\
\text { "No" indicates cold bins do not have vertical dividers. }\end{array}$ & $\begin{array}{l}\text { It is suggested to use vertical dividers } \\
\text { between cold bins. }\end{array}$ & \\
\hline Natural sand & Yes/No & $\begin{array}{l}\text { "Yes" indicates natural sand was observed in stockpiles. } \\
\text { "No" indicates natural sand was not observed in stockpiles. }\end{array}$ & $\begin{array}{l}\text { natural sand should not be used for asphalt } \\
\text { concrete production }\end{array}$ & \\
\hline Vibrator & Yes/No & $\begin{array}{l}\text { "Yes" indicates vibrator was used. } \\
\text { "No" indicates vibrator was not used. }\end{array}$ & Vibrator should work properly. & \\
\hline $\begin{array}{l}\text { Aggregate falling } \\
\text { into adjacent bins } \\
\text { while loading }\end{array}$ & Yes/No & $\begin{array}{l}\text { "Yes" indicates this situation was happened. } \\
\text { "No" indicates this situation was not happened. }\end{array}$ & $\begin{array}{l}\text { Aggregate falling into adjacent bins while } \\
\text { loading should be avoided. }\end{array}$ & \\
\hline $\begin{array}{l}\text { Cold bin running } \\
\text { empty }\end{array}$ & Yes/No & $\begin{array}{l}\text { "Yes" indicates cold bins were running empty. } \\
\text { "No" indicates cold bin was not running empty. }\end{array}$ & Cold bin should not run empty. & \\
\hline $\begin{array}{l}\text { Spillage from } \\
\text { conveyors }\end{array}$ & Yes/No & $\begin{array}{l}\text { "Yes" indicates spillage from conveyors was observed. } \\
\text { "No" indicates spillage from conveyors was not observed. }\end{array}$ & $\begin{array}{l}\text { Spillage from conveyors should be } \\
\text { prevented. }\end{array}$ & \\
\hline $\begin{array}{l}\text { Wind guard exist } \\
\text { on belt scale }\end{array}$ & Yes/No & $\begin{array}{l}\text { "Yes" indicates wind guard existed on belt scale. } \\
\text { "No" indicates wind guard did not exist on belt scale. }\end{array}$ & Wind guard should exist on belt scale. & \\
\hline
\end{tabular}




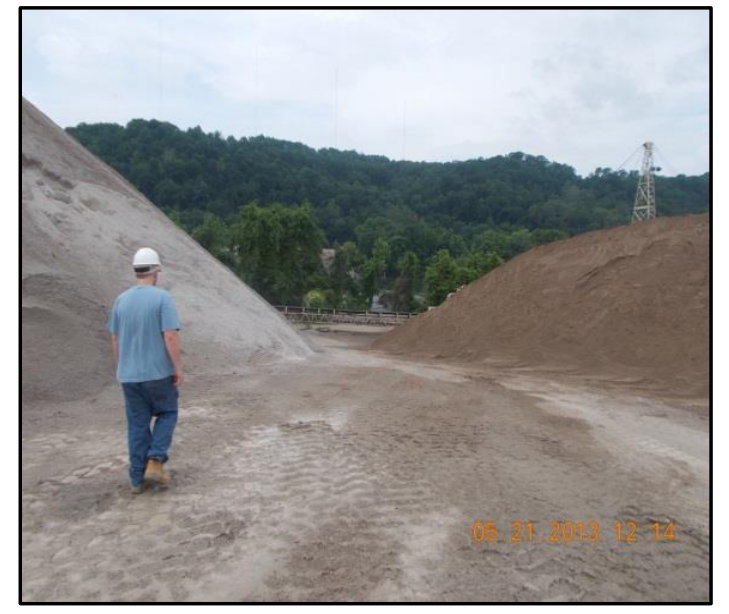

Good separation (Project Id 143)

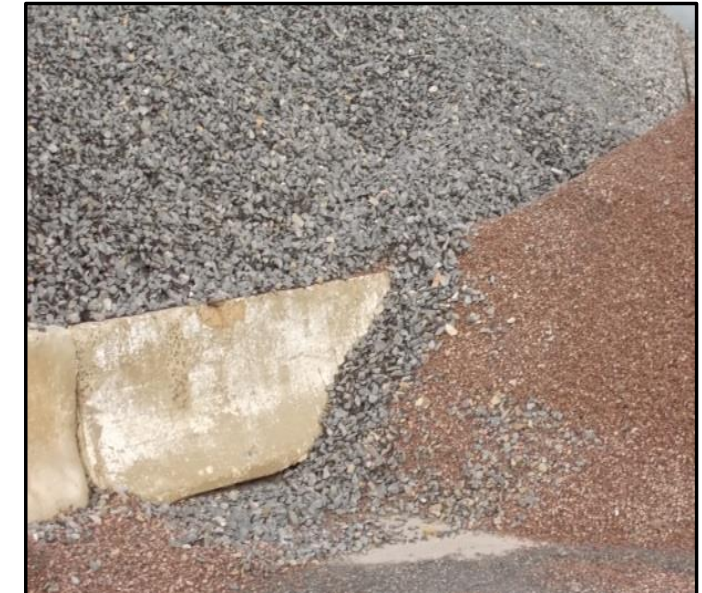

Fair separation, barrier in place but spillage observed (Project Id 34)

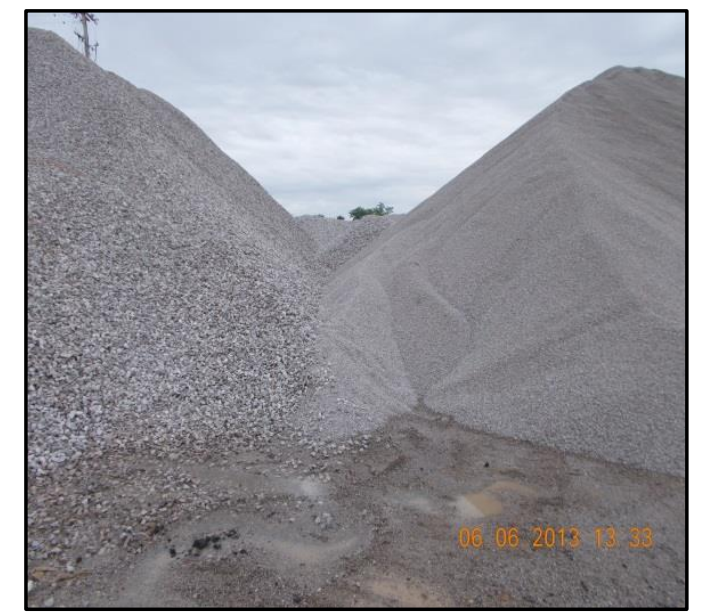

Poor separation (Project Id 142)

Figure 3-2 Stockpile separation, Good/Fair/Poor practices

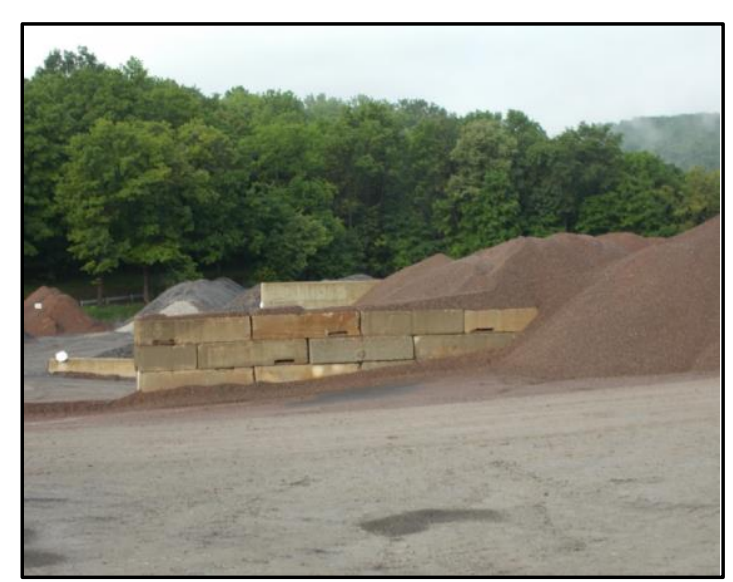

Good base condition (Project 34)

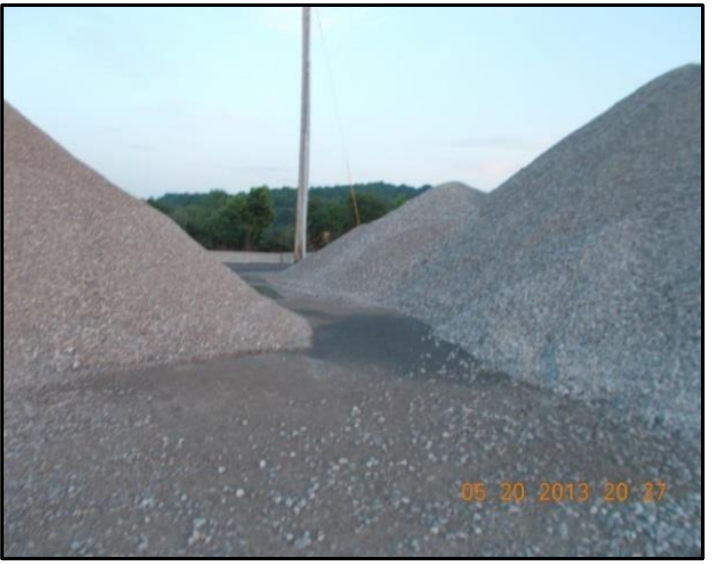

Fair base condition (Project 142)

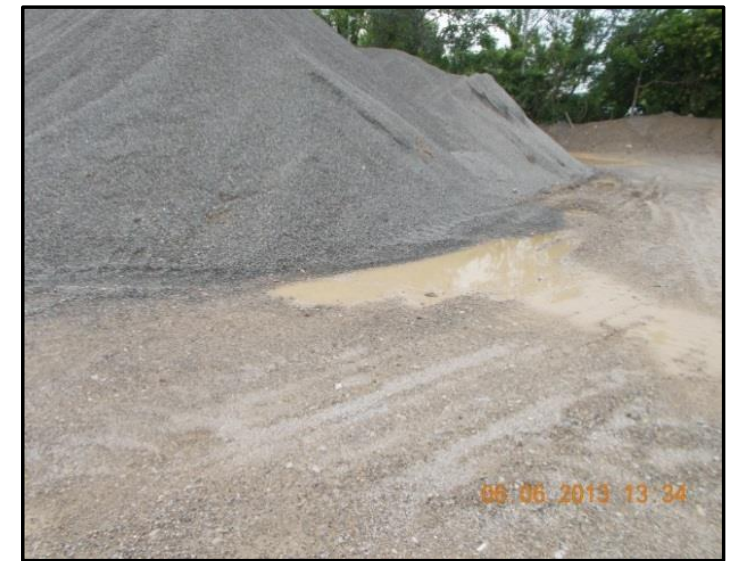

Poor base condition (Project 158)

Figure 3-3 Stockpile base condition, Good/Fair/Poor practices 


\section{SURFACE PREPARATION}

Surface preparation categories and associated phrases are presented in Table 3-3. Each category was analyzed base on descriptive phrases and related recommended practice.

Table 3-3 Phrase description and best practice for hauling categories

\begin{tabular}{|c|c|c|c|}
\hline Category & Phrase & Description of Phrase & $\begin{array}{l}\text { Recommendation for Best } \\
\text { Practice }\end{array}$ \\
\hline Surface type & $\begin{array}{l}\text { HMA/ } \\
\text { Concrete/ } \\
\text { Gravel } \\
\end{array}$ & HMA/ Concrete/ Gravel & - \\
\hline $\begin{array}{l}\text { Weather } \\
\text { temp }\end{array}$ & - & & - \\
\hline $\begin{array}{l}\text { Template } \\
\text { correction }\end{array}$ & Yes/No & $\begin{array}{l}\text { "Yes" indicates template correction } \\
\text { was done. "No" indicates template } \\
\text { correction was not done. }\end{array}$ & $\begin{array}{l}\text { Proper template correction } \\
\text { should be done. }\end{array}$ \\
\hline $\begin{array}{l}\text { Correction } \\
\text { type }\end{array}$ & $\begin{array}{l}\text { Milling/ } \\
\text { Scratch/Patch }\end{array}$ & & - \\
\hline $\begin{array}{l}\text { Surface } \\
\text { distresses }\end{array}$ & - & $\begin{array}{l}\text { Base Failure, Block Cracking, } \\
\text { Depression, Edge Cracking, Fatigue } \\
\text { Cracking, Longitudinal Cracking, } \\
\text { Potholes, Rutting, Shoulder Drop } \\
\text { off, Transverse Cracking, etc. }\end{array}$ & - \\
\hline Drainage & Yes/No & $\begin{array}{l}\text { "Yes" indicates proper drainage was } \\
\text { available. "No" indicates proper } \\
\text { drainage was not available. }\end{array}$ & $\begin{array}{l}\text { Proper drainage system } \\
\text { should be existed. }\end{array}$ \\
\hline Surface clean & Yes/No & $\begin{array}{l}\text { "Yes" indicates surface was clean } \\
\text { prior to paving. "No" indicates } \\
\text { surface was not clean prior to } \\
\text { paving. }\end{array}$ & Surface should be clean. \\
\hline $\begin{array}{l}\text { Surface } \\
\text { swept }\end{array}$ & Yes/No & $\begin{array}{l}\text { "Yes" indicates surface was swept } \\
\text { prior to paving. "No" indicates } \\
\text { surface was not swept prior to } \\
\text { paving. }\end{array}$ & Surface should be swept. \\
\hline Surface dry & Yes/No & $\begin{array}{l}\text { "Yes" indicates surface was dry } \\
\text { prior to paving. "No" indicates } \\
\text { surface was not dry prior to paving. }\end{array}$ & Surface should be dry. \\
\hline
\end{tabular}

\section{HAULING}

Hauling categories and associated phrases are presented in Table 3-4. Each category was analyzed base on descriptive phrases and related recommended practice. 
Table 3-4 Phrase description and best practice for hauling categories

\begin{tabular}{|c|c|c|c|}
\hline Category & Phrase & Description of Phrase & Recommended Practice \\
\hline Truck bed clean & Yes/No & $\begin{array}{l}\text { "Yes" indicates truck bed is clean. } \\
\text { "No" indicates truck bed is not clean. }\end{array}$ & Truck bed should be clean. \\
\hline Tailgate checked & Yes/No & $\begin{array}{l}\text { "Yes" indicates tailgate was checked. } \\
\text { "No" indicates tailgate was not checked. }\end{array}$ & $\begin{array}{l}\text { Truck tailgate should be } \\
\text { checked. }\end{array}$ \\
\hline $\begin{array}{l}\text { Truck mechanical } \\
\text { problem }\end{array}$ & Yes/No & $\begin{array}{l}\text { "Yes" indicates truck had mechanical } \\
\text { problem. "No" indicates truck did not have } \\
\text { mechanical problem. }\end{array}$ & $\begin{array}{l}\text { Truck should not have } \\
\text { mechanical problem }\end{array}$ \\
\hline Release agent used & Yes/No & $\begin{array}{l}\text { "Yes" indicates release agent was used. } \\
\text { "No" indicates release agent was not used. }\end{array}$ & $\begin{array}{l}\text { Proper release agent should be } \\
\text { used }\end{array}$ \\
\hline Release agent type & - & & Do not use diesel. \\
\hline $\begin{array}{l}\text { Excess release } \\
\text { agent drained }\end{array}$ & Yes/No & $\begin{array}{l}\text { "Yes" indicates excess release agent was } \\
\text { drained. "No" indicates excess release agent } \\
\text { was not drained. }\end{array}$ & $\begin{array}{l}\text { Excess release agent must be } \\
\text { drained }\end{array}$ \\
\hline Loading sequence & $\mathrm{F} / \mathrm{B} / \mathrm{M}$ & $\mathrm{F}=$ Front, Back=Back, $\mathrm{M}=$ Middle & $\mathrm{F} / \mathrm{B} / \mathrm{M}$ or $\mathrm{B} / \mathrm{F} / \mathrm{M}$ \\
\hline Tarp & Yes/No & $\begin{array}{l}\text { "Yes" indicates tarp was used. } \\
\text { "No" indicates tarp was not used. }\end{array}$ & $\begin{array}{l}\text { Tarp should be used to preserve } \\
\text { HMA temperature. }\end{array}$ \\
\hline $\begin{array}{l}\text { Asphalt } \\
\text { temperature in the } \\
\text { truck }\end{array}$ & - & - & \\
\hline $\begin{array}{l}\text { Loading tickets } \\
\text { picked up }\end{array}$ & Yes/No & $\begin{array}{l}\text { "Yes" indicates loading tickets were picked } \\
\text { up by drivers. "No" indicates loading tickets } \\
\text { were not picked up by drivers. }\end{array}$ & $\begin{array}{l}\text { Loading tickets should be } \\
\text { picked up by truck driver. }\end{array}$ \\
\hline $\begin{array}{l}\text { Trucks leave } \\
\text { immediately }\end{array}$ & Yes/No & $\begin{array}{l}\text { "Yes" indicates Trucks left immediately after } \\
\text { loading. "No" indicates Trucks did not leave } \\
\text { immediately after loading. }\end{array}$ & $\begin{array}{l}\text { Trucks must leave the plant } \\
\text { immediately after loading. }\end{array}$ \\
\hline
\end{tabular}

\section{PLACEMENT}

Categories and related phrases for placement operation are presented in Table 3-5 and 3-6. Each category was analyzed base on descriptive phrases and associated recommended practice. Figures representing the ranking process follow Table 3-6. 
Table 3-5 Phrase description and recommended best practice for placement categories

\begin{tabular}{|c|c|c|c|c|}
\hline Category & Phrase & Description of Phrase & Recommendation for Best Practice & Figure \\
\hline Traffic control & Yes/No & $\begin{array}{l}\text { "Yes" indicates traffic control was done prior to paving. } \\
\text { "No" indicates traffic control was not done prior to paving. }\end{array}$ & Traffic control must be done. & \\
\hline Tack coat uniformity & Good/Fair/Poor & $\begin{array}{l}\text { "Good" indicates tack coat was distributed uniformly. "Poor" indicates } \\
\text { tack coat was not distributed uniformly. "Fair" is situation between these } \\
\text { two conditions. }\end{array}$ & $\begin{array}{l}\text { Tack coat should distribute uniformly across } \\
\text { the surface. }\end{array}$ & $3-4$ \\
\hline Screed setup & Yes/No & $\begin{array}{l}\text { "Yes" indicates screed was setup before paving started. } \\
\text { "No" indicates screed was not setup before paving started. }\end{array}$ & $\begin{array}{l}\text { Paver screed should be setup prior HMA } \\
\text { placing start. }\end{array}$ & \\
\hline Paver screed heated & Yes/No & $\begin{array}{l}\text { "Yes" indicates paver screed was heated before paving started. } \\
\text { "No" indicates paver screed was not heated before paving started. }\end{array}$ & $\begin{array}{l}\text { Paver screed should be heated prior HMA } \\
\text { placing start. }\end{array}$ & \\
\hline Excess tack & Yes/No & $\begin{array}{l}\text { "Yes" indicates excess tack coat. } \\
\text { "No" indicates tack coat was not excessive. }\end{array}$ & $\begin{array}{l}\text { Hot sand should be placed on areas with } \\
\text { excess tack coat. }\end{array}$ & \\
\hline Tack coat hand spray & Yes/No & $\begin{array}{l}\text { "Yes" indicates tack coat was distributed by hand spray as needed. } \\
\text { "No" indicates tack coat was needed and not applied. }\end{array}$ & & \\
\hline Tack coat break & Yes/No & $\begin{array}{l}\text { "Yes" indicates tack coat was broken before paving started. } \\
\text { "No" indicates tack coat was not broken before paving started. }\end{array}$ & $\begin{array}{l}\text { Tack coat should be broken prior HMA } \\
\text { placing; color changes from brown to black. }\end{array}$ & \\
\hline $\begin{array}{l}\text { Trucks available at } \\
\text { startup }\end{array}$ & Yes/No & $\begin{array}{l}\text { "Yes" indicates trucks were available prior paving started. } \\
\text { "No" indicates there was no truck available prior paving started. }\end{array}$ & Trucks must present at startup. & \\
\hline Material delivery & $\begin{array}{l}\text { Consistent/ } \\
\text { Not-consistent }\end{array}$ & $\begin{array}{l}\text { "Consistent" indicates paver never stopped and the asphalt material was } \\
\text { provided consistently during the HMA placement. "Not-consistent" } \\
\text { indicates paver stopped frequently. }\end{array}$ & $\begin{array}{l}\text { Material should be delivered into paver } \\
\text { consistently. }\end{array}$ & \\
\hline $\begin{array}{l}\text { Material segregation } \\
\text { in the truck }\end{array}$ & Yes/No & $\begin{array}{l}\text { "Yes" indicates material segregation was observed in the truck. "No" } \\
\text { indicates material segregation was not observed in the truck. }\end{array}$ & $\begin{array}{l}\text { Material segregation in the truck should be } \\
\text { avoided. }\end{array}$ & \\
\hline Load break & Yes/No & $\begin{array}{l}\text { "Yes" indicates truck load was broken before deliver to the paver. "No" } \\
\text { indicates truck load was not broken before deliver to the paver. }\end{array}$ & $\begin{array}{l}\text { The truck bed should be raised slightly until } \\
\text { the HMA moves against the tailgate }\end{array}$ & \\
\hline $\begin{array}{l}\text { Truck \& paver } \\
\text { connection }\end{array}$ & $\begin{array}{l}\text { Truck bump the } \\
\text { paver / Truck did } \\
\text { not bump the paver }\end{array}$ & & $\begin{array}{l}\text { Truck should stop in front of paver; paver } \\
\text { travels forward to engage truck }\end{array}$ & \\
\hline MTV & Used/Not Used & $\begin{array}{l}\text { "Used" indicates Material Transfer Vehicle was used. } \\
\text { "Not Used" indicates Material Transfer Vehicle was not used. }\end{array}$ & $\begin{array}{l}\text { It is recommended to use MTV to deliver } \\
\text { material into paver hopper. }\end{array}$ & \\
\hline Hopper overflow & Yes/No & $\begin{array}{l}\text { "Yes" means there was at least one hopper overflow during construction. } \\
\text { "No" means there was not any hopper overflow during construction. }\end{array}$ & Hopper overflow should be prevented. & \\
\hline Screed vibrator & Used/Not Used & $\begin{array}{l}\text { "Used" indicates paver screed vibrator was on. } \\
\text { "Not Used" indicates paver screed vibrator was off. }\end{array}$ & $\begin{array}{l}\text { It is recommended to use screed vibrator } \\
\text { during paving. }\end{array}$ & \\
\hline Material head sensor & Used/Not Used & $\begin{array}{l}\text { "Used" indicates Material head sensor was used. } \\
\text { "Not Used" indicates Material head sensor was not used. }\end{array}$ & Material head sensor should be used. & \\
\hline
\end{tabular}


Table 3-6 Phrase description and recommended best practice for placement categories (continued)

\begin{tabular}{|c|c|c|c|c|}
\hline Category & Phrase & Description of Phrase & Recommendation for Best Practice & Figure \\
\hline $\begin{array}{l}\text { Material distribution } \\
\text { across the auger }\end{array}$ & Good/Fair/Poor & $\begin{array}{l}\text { "Good" indicates material was distributed uniformly across the auger. } \\
\text { "Poor" indicates material was not distributed uniformly across the auger. } \\
\text { "Fair" is situation between these two conditions. }\end{array}$ & $\begin{array}{l}\text { Material should be distributed uniformly } \\
\text { across the auger. }\end{array}$ & $3-5$ \\
\hline Slope \& level sensors & Used/Not Used & $\begin{array}{l}\text { "Used" indicates slope \& level sensors was used. "Not Used" indicates } \\
\text { slope \& level sensors was not used. }\end{array}$ & Slope \& level sensors should be used. & \\
\hline Hopper wings & $\begin{array}{l}\text { Folded once per } \\
\text { Load/Not Folded at } \\
\text { all/Folded when } \\
\text { Material is Low }\end{array}$ & $\begin{array}{c}\text { "Folded" indicates hopper wings were folded during paver operation. } \\
\text { "Not Folded" indicates hopper wings were not folded during paver } \\
\text { operation. }\end{array}$ & $\begin{array}{l}\text { Paver hopper wings should not be folded at } \\
\text { all. }\end{array}$ & \\
\hline Thickness check & $\begin{array}{l}\text { Frequently/Rarely/ } \\
\text { Not at All }\end{array}$ & $\begin{array}{l}\text { "Frequently" indicates new HMA layer thickness was checked frequently. } \\
\text { "Rarely" indicates layer thickness was checked rarely. "Not at All" } \\
\text { indicates layer thickness was not checked at all. }\end{array}$ & $\begin{array}{l}\text { New HMA layer thickness should be } \\
\text { checked frequently during paver operation. }\end{array}$ & \\
\hline Cross slope check & $\begin{array}{l}\text { Frequently/Rarely/ } \\
\text { Not at All }\end{array}$ & $\begin{array}{l}\text { "Frequently" indicates pavement cross slope was checked frequently. } \\
\text { "Rarely" indicates pavement cross slope was checked rarely. "Not at All" } \\
\text { indicates pavement cross slope was not checked at all. }\end{array}$ & Check pavement cross slope frequently. & \\
\hline $\begin{array}{l}\text { Surface texture } \\
\text { behind the paver }\end{array}$ & Good/Fair/Poor & $\begin{array}{l}\text { "Good" indicates proper (unsegregated) surface texture behind the paver. } \\
\text { "Poor" indicates week or segregated surface texture behind the paver. } \\
\text { "Fair" is situation between these two conditions. }\end{array}$ & $\begin{array}{l}\text { Smooth and unsegregated surface texture } \\
\text { behind the paver }\end{array}$ & $3-6$ \\
\hline Truck bed cleaning & $\begin{array}{l}\text { In front of paver / } \\
\text { Truck bed material } \\
\text { was removed/ } \\
\text { Designated Cleaning } \\
\text { Area /On the } \\
\text { Shoulder } \\
\end{array}$ & 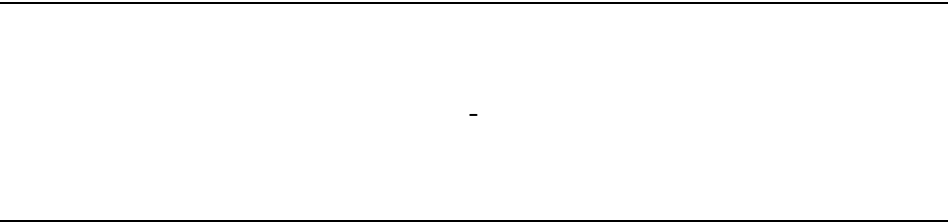 & $\begin{array}{l}\text { Clean truck bed in designated area prior to } \\
\text { returning to plant. }\end{array}$ & \\
\hline Luting & Good/Fair/Poor & $\begin{array}{l}\text { "Good" indicates proper luting procedure. "Poor" indicates improper } \\
\text { luting procedure. "Fair" is situation between these two conditions. }\end{array}$ & $\begin{array}{l}\text { Luting should be minimized at joints. } \\
\text { Material should not be pushed onto the hot } \\
\text { mat. }\end{array}$ & $3-7$ \\
\hline
\end{tabular}




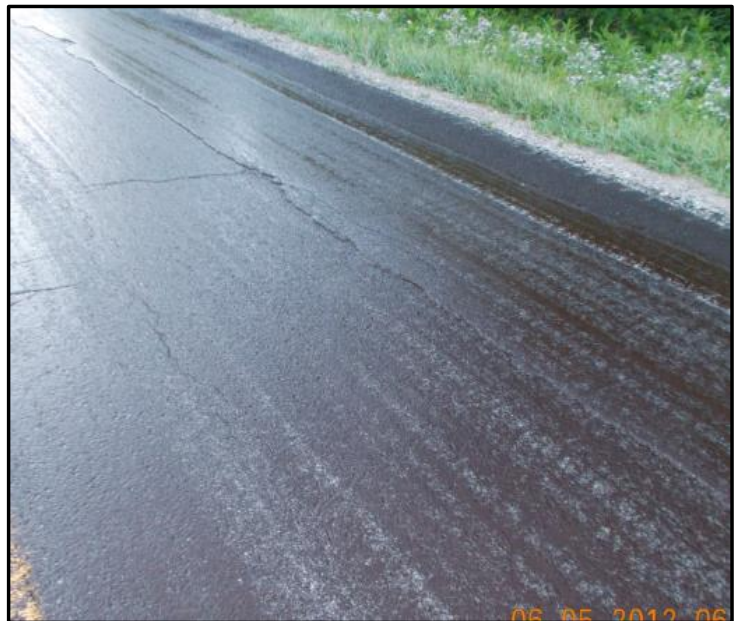

Good (Project Id 9)

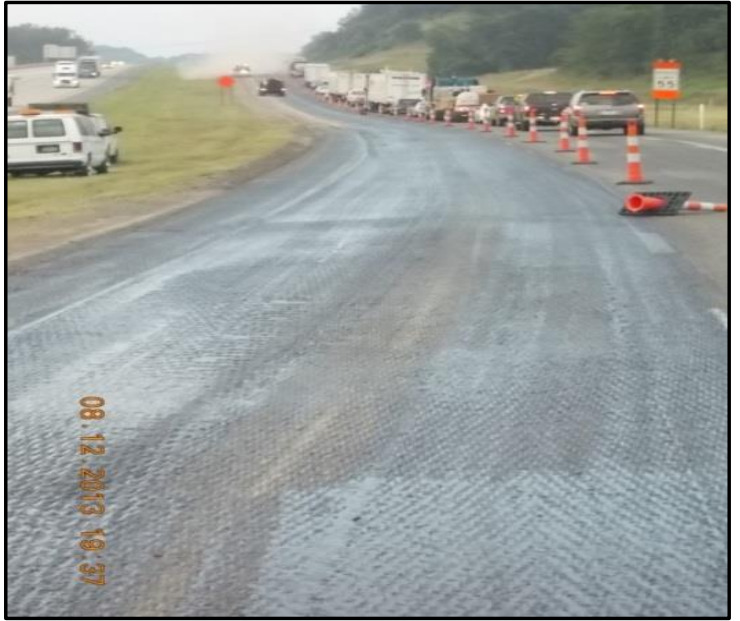

Fair (Project Id 212)

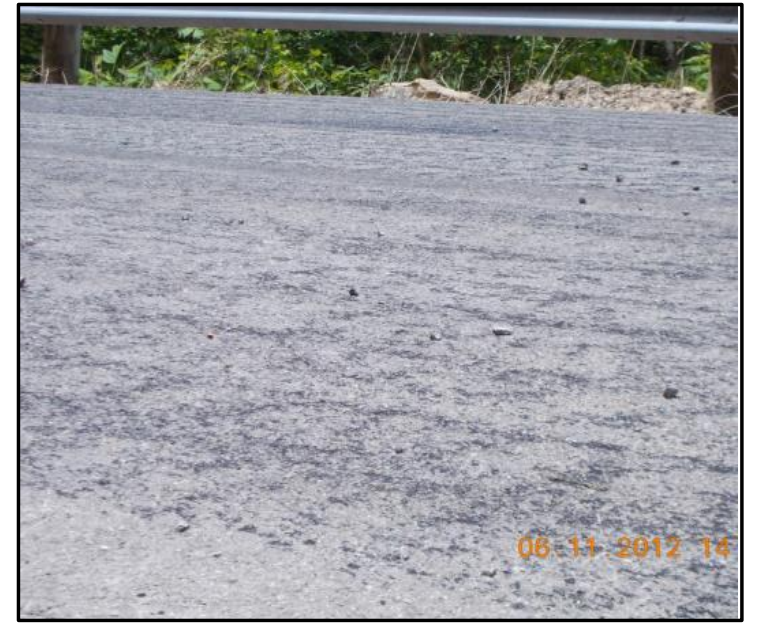

Poor (Project Id 122)

Figure 3-4 Tack coat uniformity, Good/Fair/Poor practices

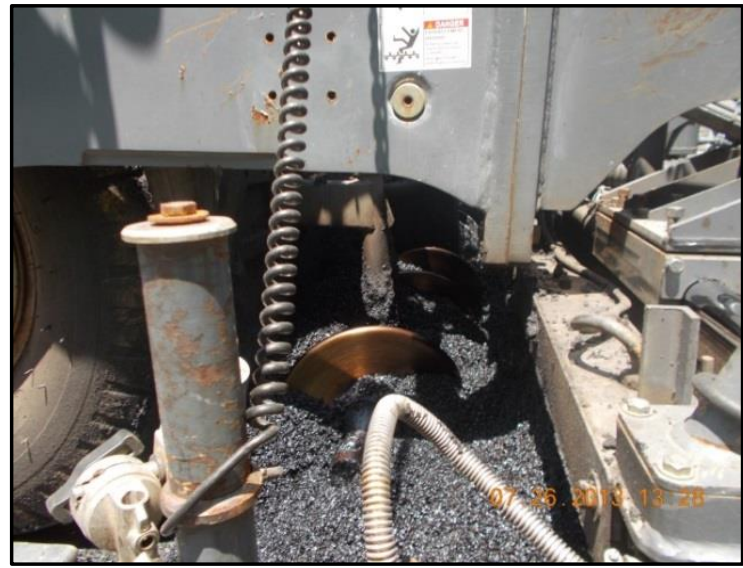

Good (Project Id 205)

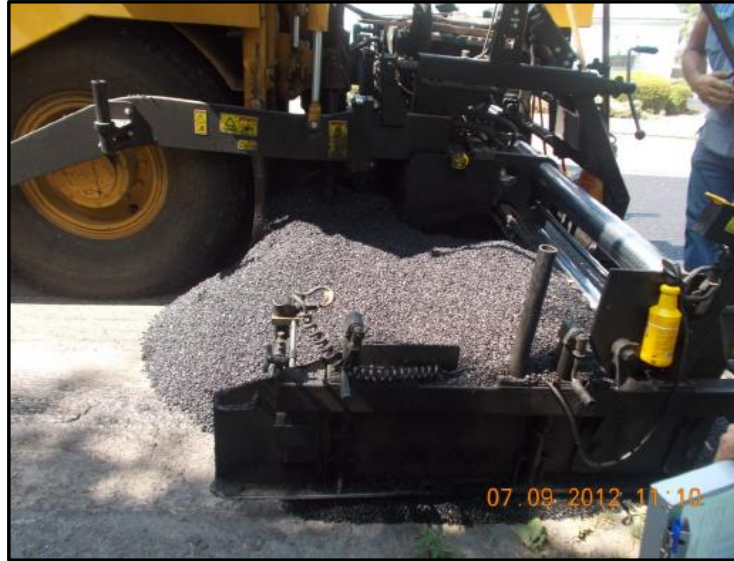

Poor (Project Id 70)

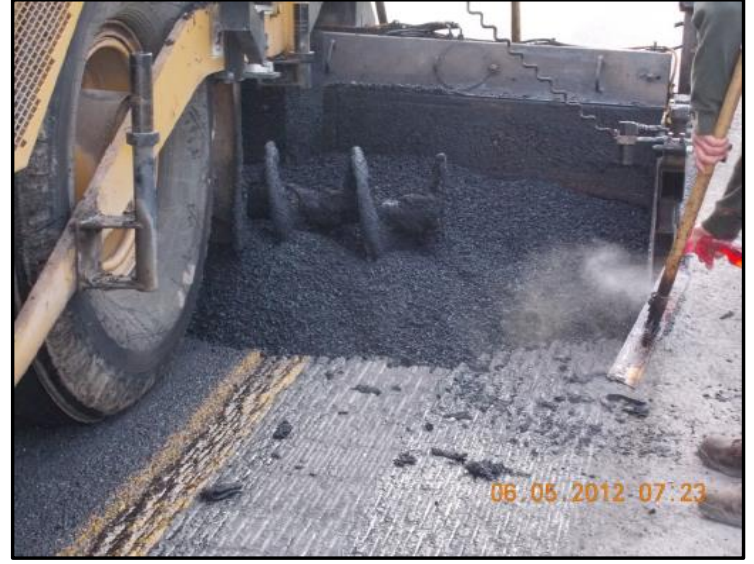

Poor (Project Id 52)

Figure 3-5 Material distribution across the auger, Good/Poor practices 


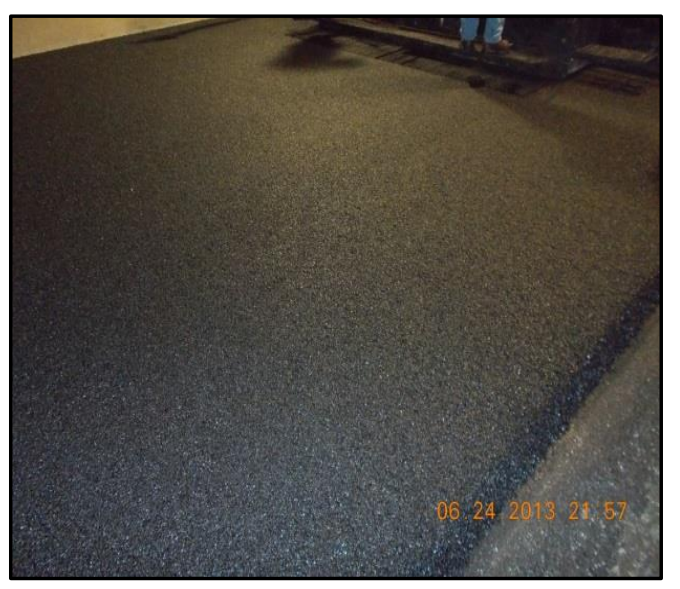

Good (Project Id 159)

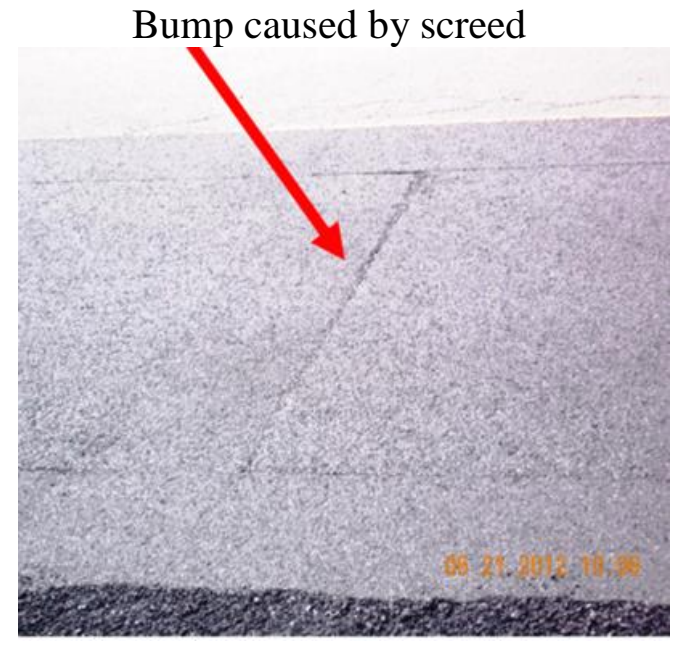

Poor (Project Id 46)

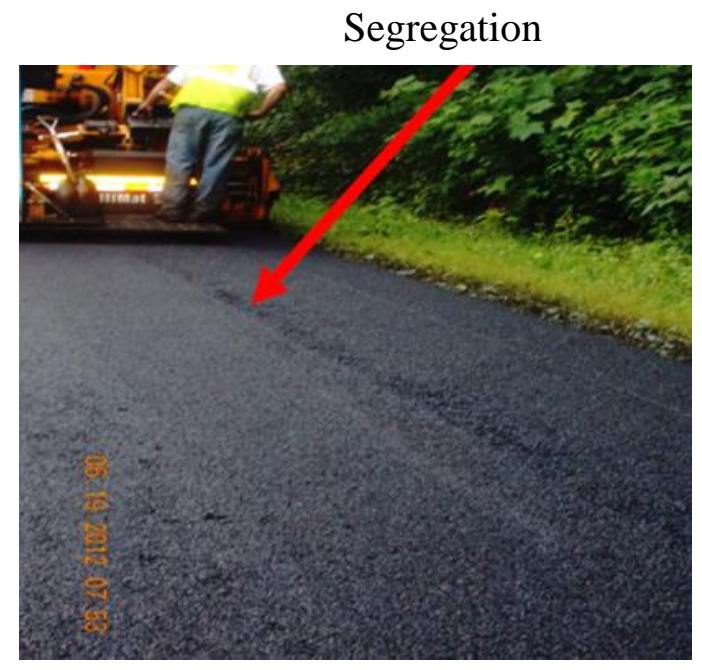

Poor (Project Id 122)

Figure 3-6 Surface texture behind the paver, Good /Poor practices

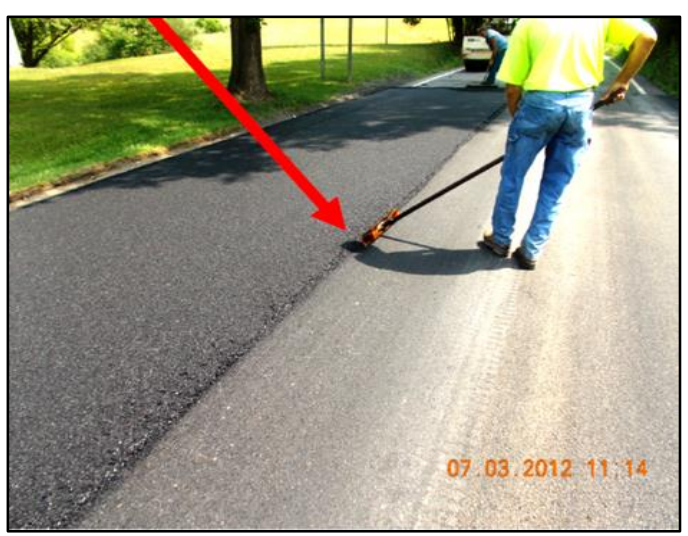

Good longitudinal joint luting practice (Project Id 68)

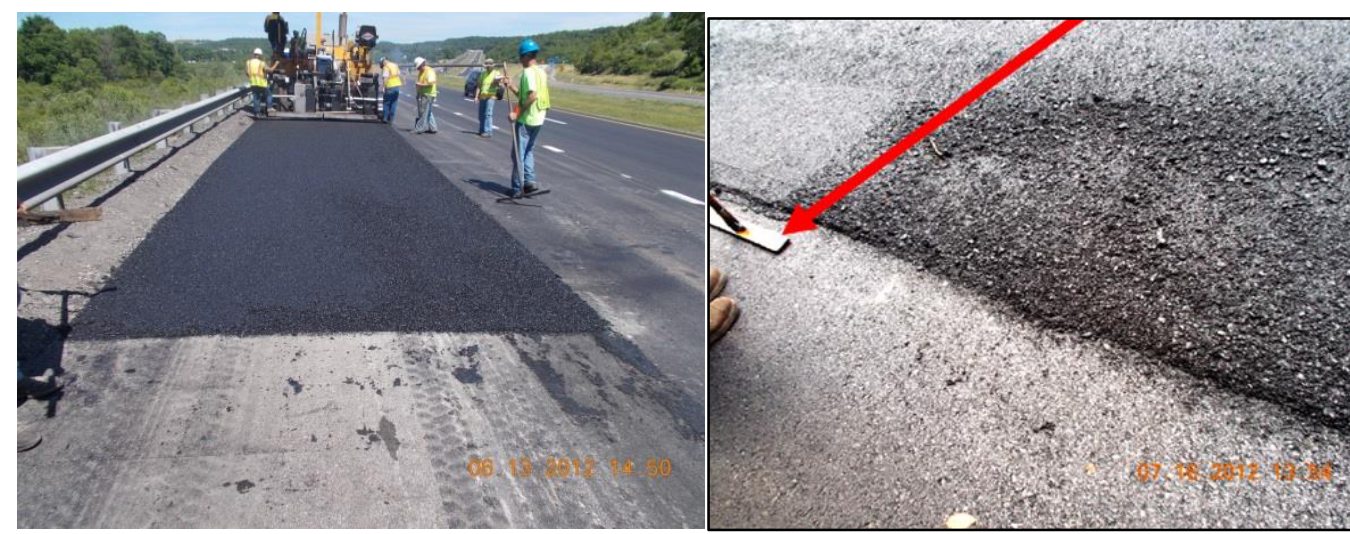

Fair - Luting should be minimized for transverse joint (Project Id 57)

Figure 3-7 Luting, Good/Fair/Poor practice
Poor - Pushing material too far at longitudinal joint (Project Id 74) 


\section{COMPACTION}

Compaction categories and associated phrases are presented in Table 3-7. Each category was analyzed base on descriptive phrases and related recommended practice. Figures 3.8 and 3.9 show good and poor roller practices for longitudinal and transverse joints respectively.

Rollers passes were recorded by cameras for some projects during the summer 2013. In addition, co-ops reported their field observation with/without using cameras. Camera records were compared to the co-ops observations to evaluate the reliability of the observations.

Roller passes pictures were taken at intervals of 2 or 5 seconds to allow extended observation times. The pictures were put to getter to produce video files by Microsoft Movie Maker software. Then the numbers of roller passes were counted and documented in Microsoft Access database. In next chapter the results are presented and discussed.

Breakdown, intermediate and finish rolling passes cannot observe by cameras pictures. As a result, only the numbers of passes by a roller in a rolling zone were observed. 


\section{Table 3-7 Phrase description and recommended best practice for compaction categories}

\begin{tabular}{|c|c|c|c|c|}
\hline Category & Phrase & Description of Phrase & Recommendation for Best Practice & Figure \\
\hline $\begin{array}{l}\text { Roller } \\
\text { hydraulic leak }\end{array}$ & Yes/No & $\begin{array}{l}\text { "Yes" indicates roller had leak. } \\
\text { "No" indicates roller did not have liquid leak. }\end{array}$ & $\begin{array}{l}\text { Roller should be checked prior } \\
\text { paving operation and it should be } \\
\text { mechanically sound. }\end{array}$ & \\
\hline Roller nozzles & $\begin{array}{l}\text { All working/ not } \\
\text { working }\end{array}$ & $\begin{array}{l}\text { "All working" indicates all roller nozzle were working } \\
\text { properly. "Not working" indicates the roller nozzles } \\
\text { were not working properly. }\end{array}$ & $\begin{array}{l}\text { Roller nozzles should be checked } \\
\text { prior paving operation and they } \\
\text { should work properly. }\end{array}$ & \\
\hline Roller scrapers & $\begin{array}{l}\text { Roller scrapers } \\
\text { not touching/ } \\
\text { Sound and work } \\
\text { fine/ Worn out }\end{array}$ & $\begin{array}{l}\text { "Roller scrapers not touching" indicates the roller } \\
\text { scrapers did not touch each other. "Worn out" indicates } \\
\text { the roller scrappers were not sound and they were not } \\
\text { working properly. }\end{array}$ & $\begin{array}{l}\text { Roller scrapers should be checked } \\
\text { prior paving operation. They } \\
\text { should be sound and work } \\
\text { correctly. }\end{array}$ & \\
\hline $\begin{array}{l}\text { Roller drums } \\
\text { kept moist }\end{array}$ & Yes/No & $\begin{array}{l}\text { "Yes" indicates roller drums were kept moist. } \\
\text { "No" indicates roller drums were not kept moist. }\end{array}$ & Roller drums must be kept moist. & \\
\hline $\begin{array}{l}\text { Stopping on hot } \\
\text { mat }\end{array}$ & Yes/No & $\begin{array}{l}\text { "Yes" indicates at least one stopping on hot material by } \\
\text { roller was observed. "No" indicates roller did not stop } \\
\text { on hot mat. }\end{array}$ & $\begin{array}{l}\text { Roller should not stop on hot } \\
\text { material. }\end{array}$ & \\
\hline $\begin{array}{l}\text { Visible roller } \\
\text { marks after } \\
\text { compaction is } \\
\text { complete }\end{array}$ & Yes/No & $\begin{array}{l}\text { "Yes" indicates at least one defect was observed after } \\
\text { roller operation. "No" indicates no defects were } \\
\text { observed after roller operation. }\end{array}$ & $\begin{array}{l}\text { No defect should be visible at the } \\
\text { end of compaction operation. }\end{array}$ & \\
\hline $\begin{array}{l}\text { Transverse joint } \\
\text { compaction }\end{array}$ & $\begin{array}{l}\text { Perpendicular/ } \\
\text { Parallel }\end{array}$ & $\begin{array}{l}\text { "Perpendicular" indicates transverse joint compaction } \\
\text { was perpendicular to the paving direction. "Parallel" } \\
\text { indicates transverse joint compaction was parallel to } \\
\text { the paving direction. }\end{array}$ & $\begin{array}{l}\text { Transverse joint compaction } \\
\text { should be perpendicular to the } \\
\text { paving direction }\end{array}$ & $3-8$ \\
\hline $\begin{array}{l}\text { Longitudinal } \\
\text { joint } \\
\text { compaction }\end{array}$ & $\begin{array}{l}\text { Hot side / Cold } \\
\text { side/ Equal/ } \\
\text { Random }\end{array}$ & $\begin{array}{l}\text { Hot side - roller is predominately on hot mat with } \\
\text { some overlap onto cold side. } \\
\text { Cold side - roller is predominately on cold mat with } \\
\text { some overlap onto hot side. } \\
\text { Equal - center of roller was approximately over the } \\
\text { joint. } \\
\text { Random - indicate a combination }\end{array}$ & $\begin{array}{l}\text { Roller should be on the hot mat } \\
\text { with slight overlap onto cold side. }\end{array}$ & $3-9$ \\
\hline Roller pattern & $\begin{array}{l}\text { Uniform/ } \\
\text { non-uniform }\end{array}$ & $\begin{array}{l}\text { Uniform - roller makes a consistent number of passes } \\
\text { over the entire mat } \\
\text { Non-uniform - the number of passes was not consistent } \\
\text { over the mat. }\end{array}$ & $\begin{array}{l}\text { Number of passes should be } \\
\text { consistent as determined by the } \\
\text { roller pattern }\end{array}$ & \\
\hline
\end{tabular}




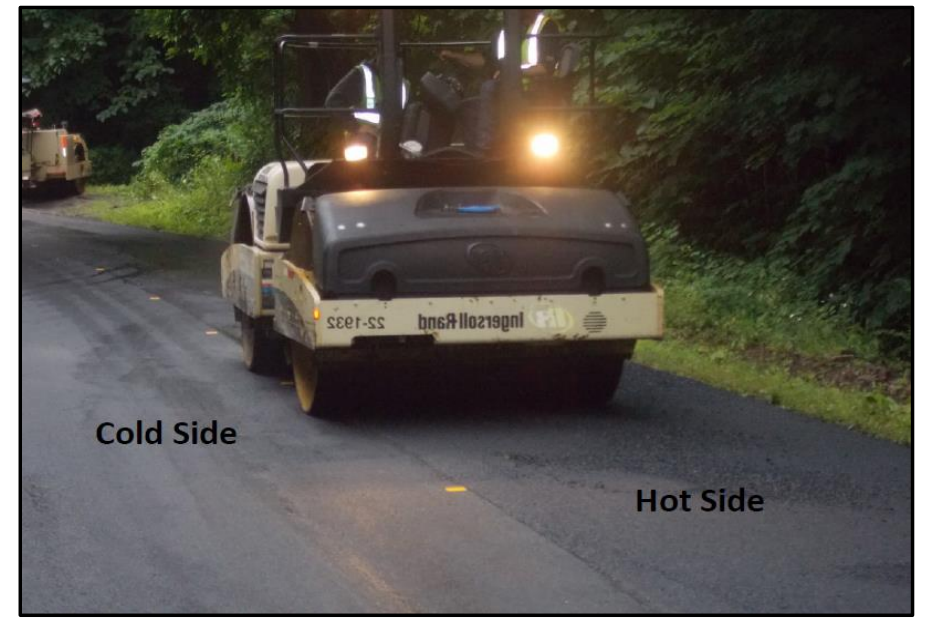

Good roller placement hot-to-cold (Project Id 66)

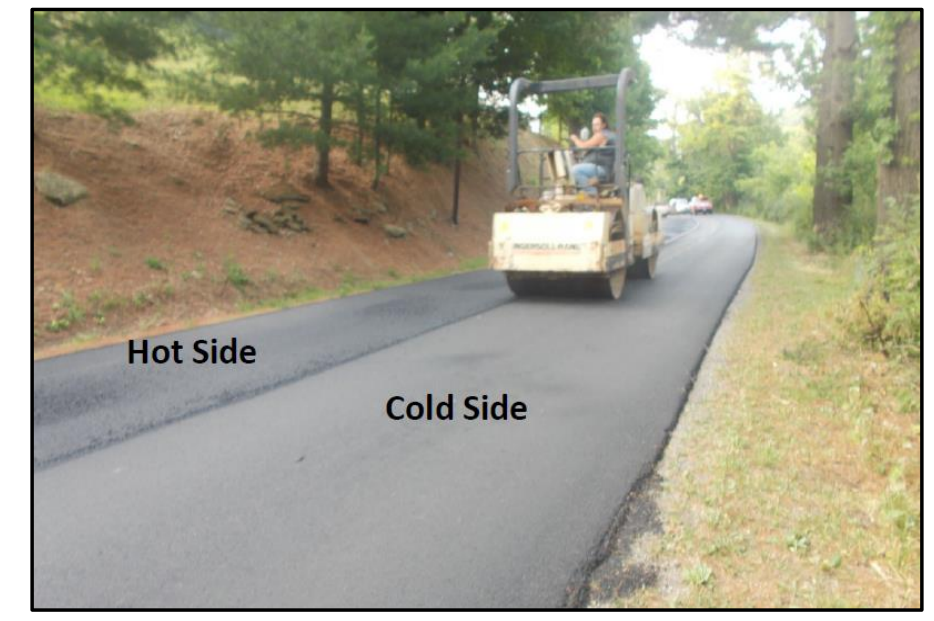

Poor roller placement cold-to-hot (Project Id 93)

Figure 3-8 Longitudinal joint compaction

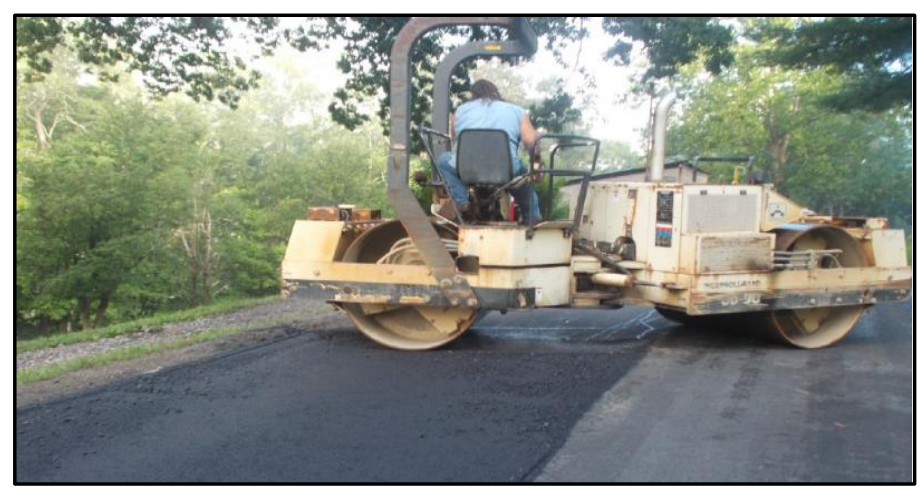

Good Compaction perpendicular to paving direction (Project Id 80)

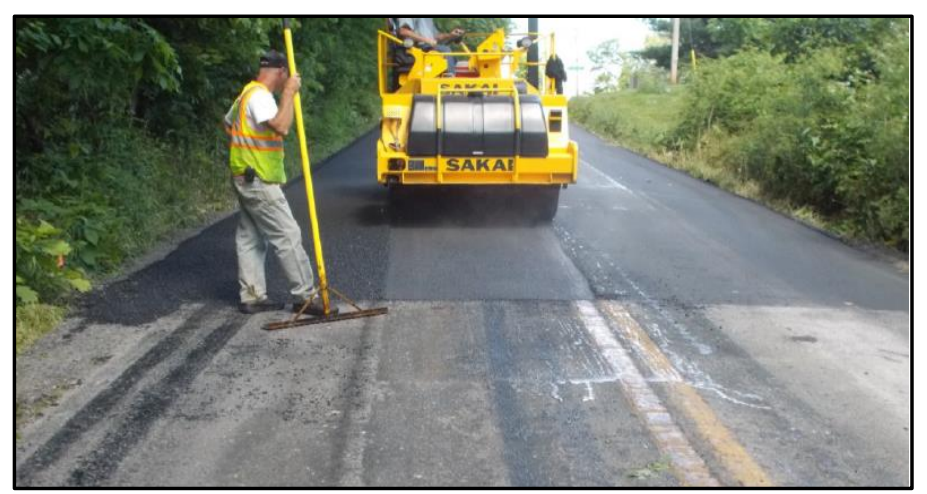

Poor Compaction parallel to paving direction (Project Id 38)

Figure 3-9 Transverse joint compaction 


\section{SHOULDER WIDENING}

Shoulder widening categories and associated phrases are presented in Table 3-8.

Additionally, description of phrase and the best practice for each category are presented.

\section{Table 3-8 Phrase description and recommended best practice for shoulder widening categories}

\begin{tabular}{|c|c|c|c|}
\hline Category & $\begin{array}{l}\text { Presenting } \\
\text { Phrase }\end{array}$ & Description of Phrase & $\begin{array}{l}\text { Recommendation for Best } \\
\text { Practice }\end{array}$ \\
\hline Trench & Yes/No & $\begin{array}{l}\text { "Yes" indicates shoulder widening was done by } \\
\text { digging trench. "No" indicates shoulder widening } \\
\text { was not done by digging trench. }\end{array}$ & $\begin{array}{l}\text { The first step is to dig a } \\
\text { trench in shoulder widening. }\end{array}$ \\
\hline $\begin{array}{l}\text { Trench } \\
\text { bottom } \\
\text { compacted }\end{array}$ & Yes/No & $\begin{array}{l}\text { "Yes" indicates bottom of trench was compacted. } \\
\text { "No" indicates bottom of trench was not } \\
\text { compacted. }\end{array}$ & $\begin{array}{l}\text { Bottom of trench should be } \\
\text { compacted properly }\end{array}$ \\
\hline $\begin{array}{l}\text { Trench } \\
\text { bottom is } \\
\text { clean }\end{array}$ & Yes/No & $\begin{array}{l}\text { "Yes" indicates bottom of trench was clean. } \\
\text { "No" indicates bottom of trench was not clean. }\end{array}$ & $\begin{array}{l}\text { Bottom of trench should be } \\
\text { clean. }\end{array}$ \\
\hline $\begin{array}{l}\text { Vegetation } \\
\text { removed }\end{array}$ & Yes/No & $\begin{array}{l}\text { "Yes" indicates surface vegetation was removed } \\
\text { before paving. "No" indicates surface vegetation } \\
\text { was not removed before paving. }\end{array}$ & $\begin{array}{l}\text { Bottom of trench should be } \\
\text { lack of any vegetation. }\end{array}$ \\
\hline $\begin{array}{l}\text { Pavement } \\
\text { edges tacked }\end{array}$ & Yes/No & $\begin{array}{l}\text { "Yes" indicates tack coat was distributed across } \\
\text { the edge of pavement. "No" indicates tack coat } \\
\text { was not distributed across the edge of pavement. }\end{array}$ & $\begin{array}{l}\text { Tack coat should be } \\
\text { distributed over the edge of } \\
\text { pavement. }\end{array}$ \\
\hline $\begin{array}{l}\text { Pavement } \\
\text { edges intact }\end{array}$ & Yes/No & $\begin{array}{l}\text { "Yes" indicates pavement edge was intact. } \\
\text { "No" indicates pavement edge was not intact. }\end{array}$ & $\begin{array}{l}\text { Pavement edges should be } \\
\text { milled and should not be } \\
\text { kept intact. }\end{array}$ \\
\hline Special paver & Yes/No & $\begin{array}{l}\text { "Yes" indicates special paver was used for } \\
\text { shoulder widening. "No" indicates special paver } \\
\text { was not used for shoulder widening }\end{array}$ & $\begin{array}{l}\text { Special paver should be } \\
\text { used. }\end{array}$ \\
\hline $\begin{array}{l}\text { Mix } \\
\text { segregation }\end{array}$ & Yes/No & $\begin{array}{l}\text { "Yes" indicates mix segregation was observed. } \\
\text { "No" indicates mix segregation was not observed. }\end{array}$ & $\begin{array}{l}\text { Mix segregation should be } \\
\text { minimized. }\end{array}$ \\
\hline
\end{tabular}

\section{TRUCKS TRAVEL TIME AND TEMPERATURE}

Truck travel time is defined as the period of time that takes each truck to reach the job site from the plant. To measure the travel time's co-ops recorded the arrival time for minimum of 10 consecutive trucks on each project. The time when each truck left the plant was obtained from the loading tickets. The average standard deviation for travel time data was calculated for each project. In order to evaluate the consistency of material delivery or hauling operation for each project, coefficient of variation $(\mathrm{COV})$ was calculated for each project. 


$$
C O V_{\text {Travel Time }}=\frac{\sigma}{\bar{T}} \quad \text { Equation } 1
$$

Where:

$\sigma:$ standard deviation of the observed travel time for a specific project

$\bar{T}$ : Mean travel time for a project

Then the average COV for all projects was calculated.

\section{TEMPERATURE DROP}

The quality of the compaction operation greatly depends on the HMA temperature. The rolling operation should be performed as quickly as possible to minimize the mat temperature drop. To evaluate the quality of the compaction operation the mat temperature was measured at three stages; after placement by the paver, before compaction started and after compaction was completed. Finally, the average surface temperature at the end of each step was obtained for all projects.

\section{CONFIDENCE IN DATA AND PERFORMANCE}

During the summer co-ops where asked to keep consistency with their data collections. However, due to the limitations and the diversity of projects it is not always possible to maintain the consistency in data collection. Therefore, it is essential to determine the data reliability for each subcategory. This information along with the performance rating can help the judgment about the contractor performance. The level of confidence in data was evaluated relative to the nature of subcategory. For instance, 5 observations for cleaning the truck bed may sound enough to make a judgment whereas it may not enough for stockpile contamination at plant. Engineering judgment pooled from a board of three trained graduate students was used to evaluate the confidence level in data for each subcategory.

In the study, the overall performance of each subcategory includes in terms of "good", "moderate" and "poor". "Good" indicates more than $75 \%$ of observed data in the subcategory were following the best construction practice. "Moderate" indicates $50 \%$ to $75 \%$ of observed data in the subcategories were following the best construction practice. "Poor" indicates less than $50 \%$ of observed data in the subcategories were following the best construction practice. 


\section{CHAPTER 4 RESULTS AND ANALYSIS}

\section{INTRODUCTION}

In this chapter the co-ops observations were analyzed and the results were discussed. All results were classified within 8 different categories:

1. Plant

2. Surface preparation

3. Hauling

4. Placement

5. Compaction

6. Shoulder widening

7. Truck travel time

8. Temperature drop

\section{PLANT}

The ratings of plant operations are presented in Table 4-1 for summer 2012 and 2013. Plant operation observations were generally indicative of good performance for both summers. Seven visits were made to six different plants in 2012 and eleven visits were made to seven plants in 2013. A medium level of confidence was found in the data received. The plant operations performances for summer 2012 and 2013 are presented in Figure 4-1. Based on the observation data, good industry performance decreases from $72 \%$ in summer 2012 into $54 \%$ in summer 2013. Several plant operation observations were selected for further analysis and comparison. Figure 4-2 through 4-5 present the percentage of the stockpiles with segregation, separation, contamination and base conditions problems for both summer 2012 and 2013. In addition, the percentages of observations for aggregate falling into adjacent bins and spillage from conveyor are presented in Figure 4-6 and 4-7. 
Table 4-1 Summary of plant observations

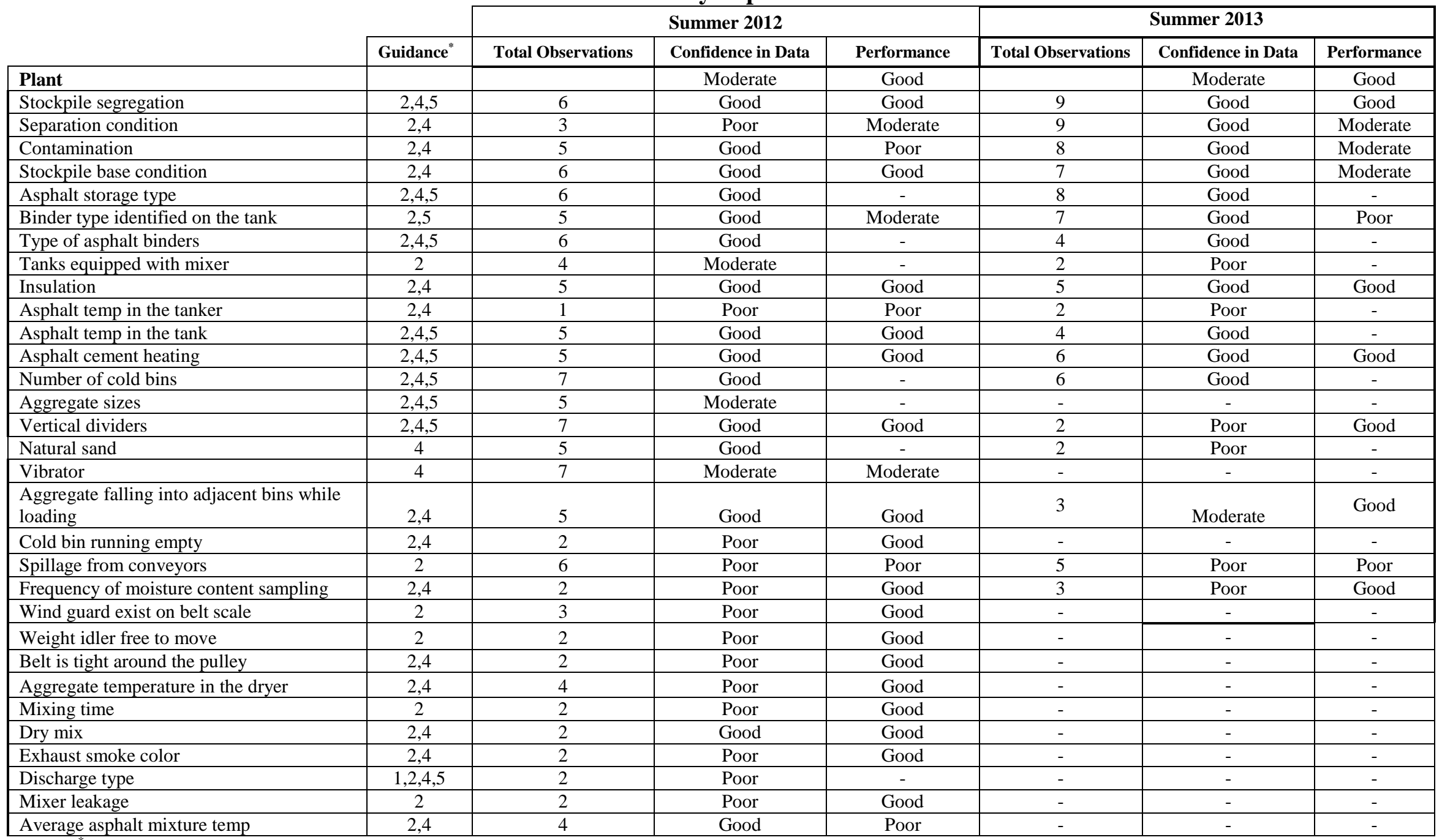
1. USAE COE 2002
2. WVDOH Road and bridge 2010
3. WVDOH Field Tech, 2013
4. WVDOH Asphalt Plant Tech, 2013
5. WVDOH Construction Manual, 2002 


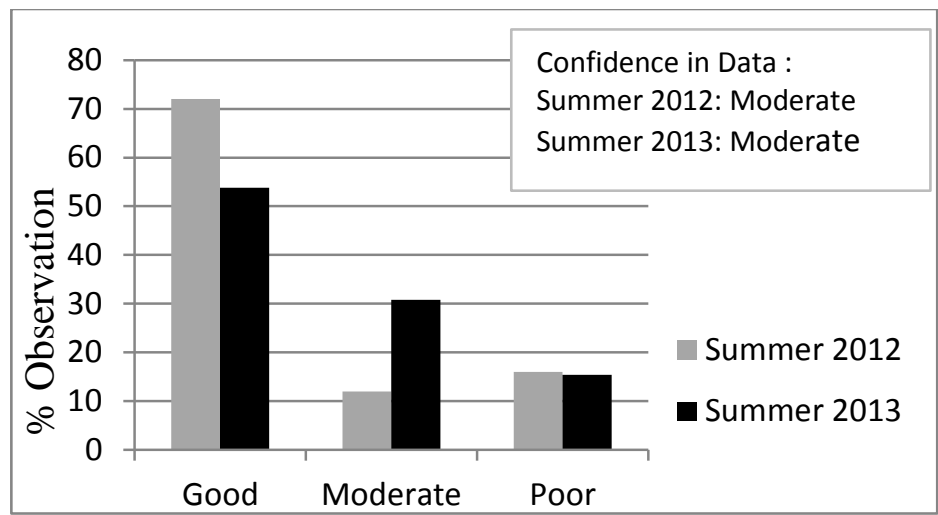

Figure 4-1 Plant operations performances in summer 2012 and 2013

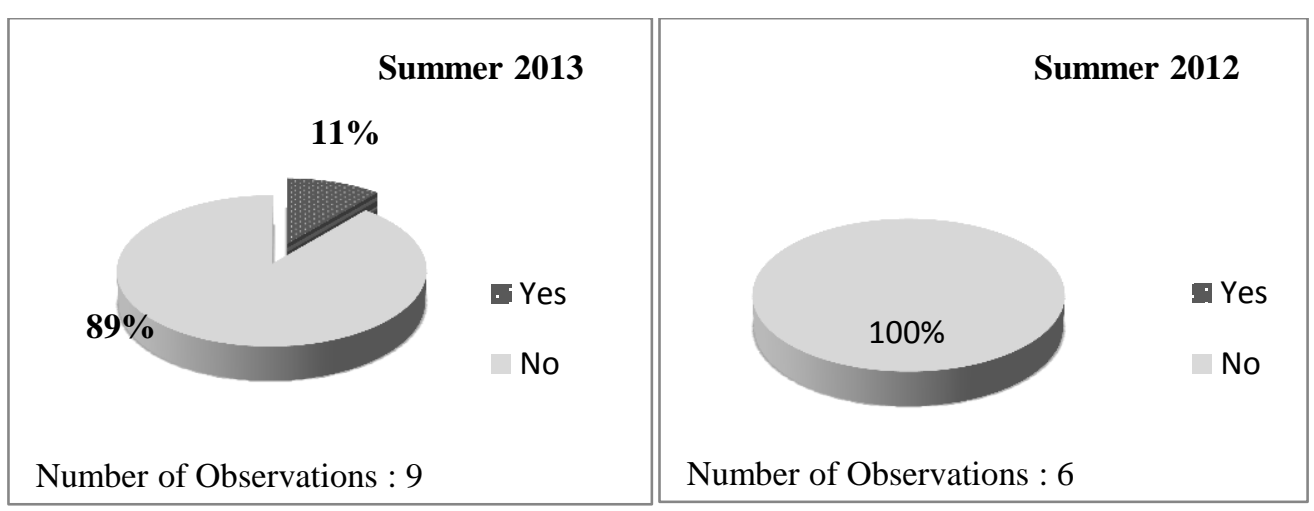

Figure 4-2 Comparison between stockpile segregation conditions in 2012 and 2013

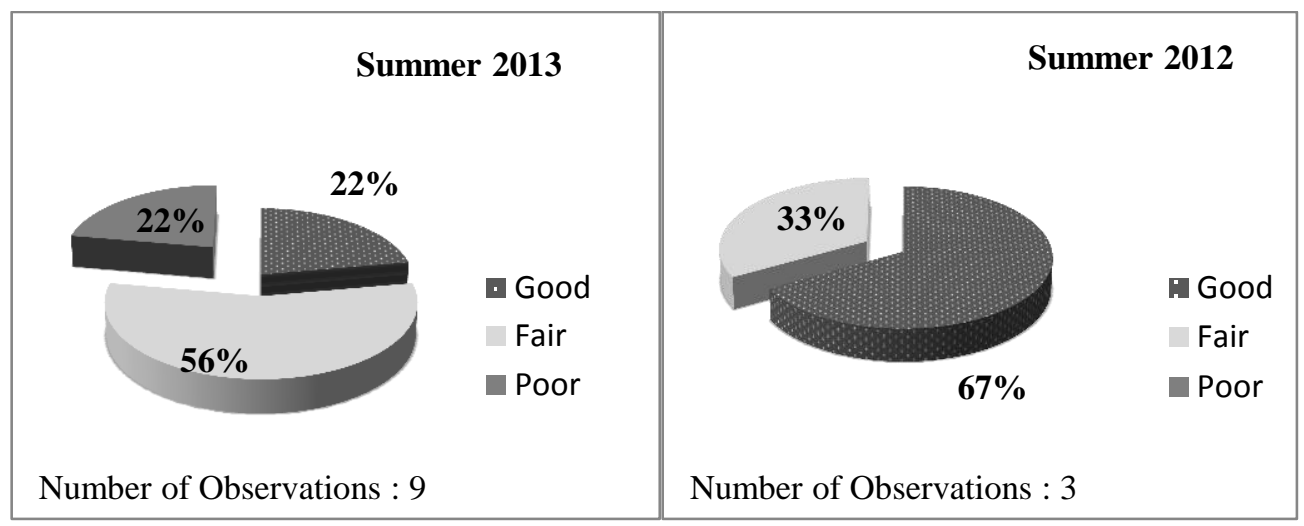

Figure 4-3 Comparison between stockpile separation conditions in 2012 and 2013 


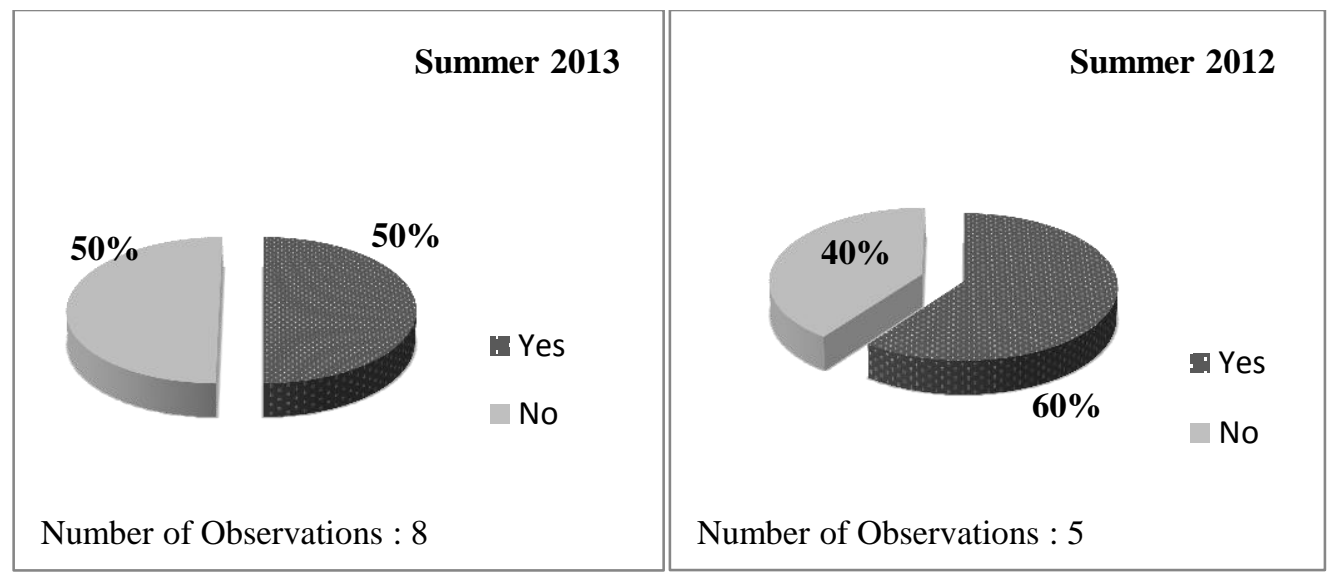

Figure 4-4 Comparison between stockpile contamination condition in 2012 and 2013

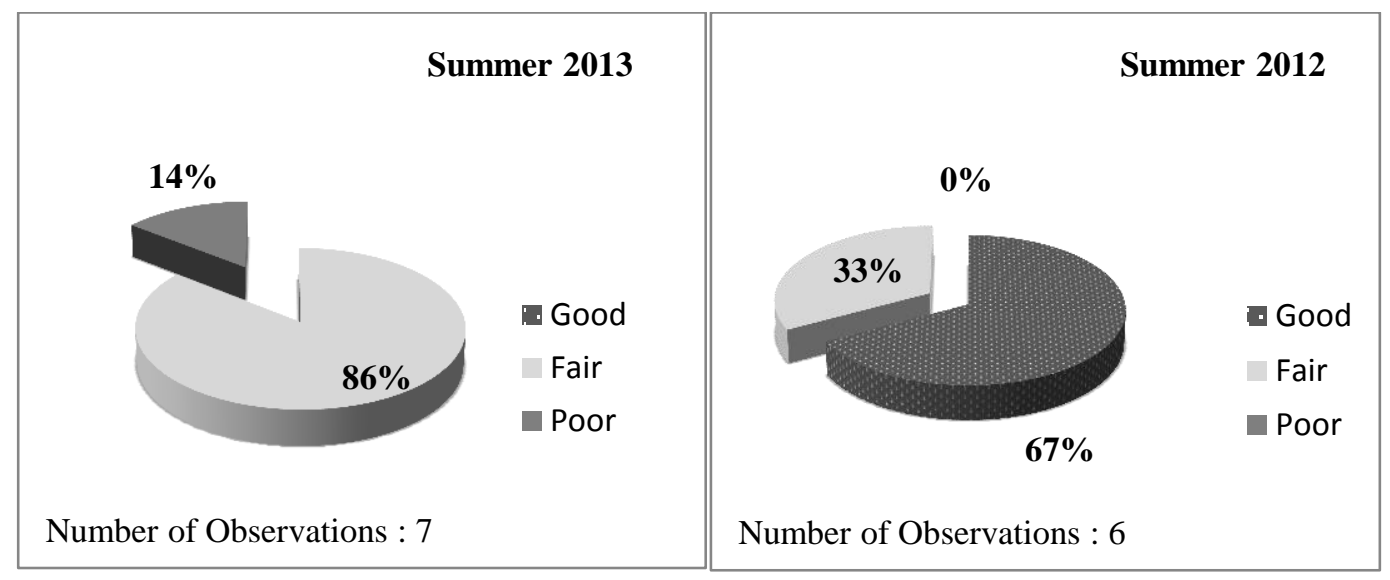

Figure 4-5 Comparison between stockpile's base conditions in 2012 and 2013

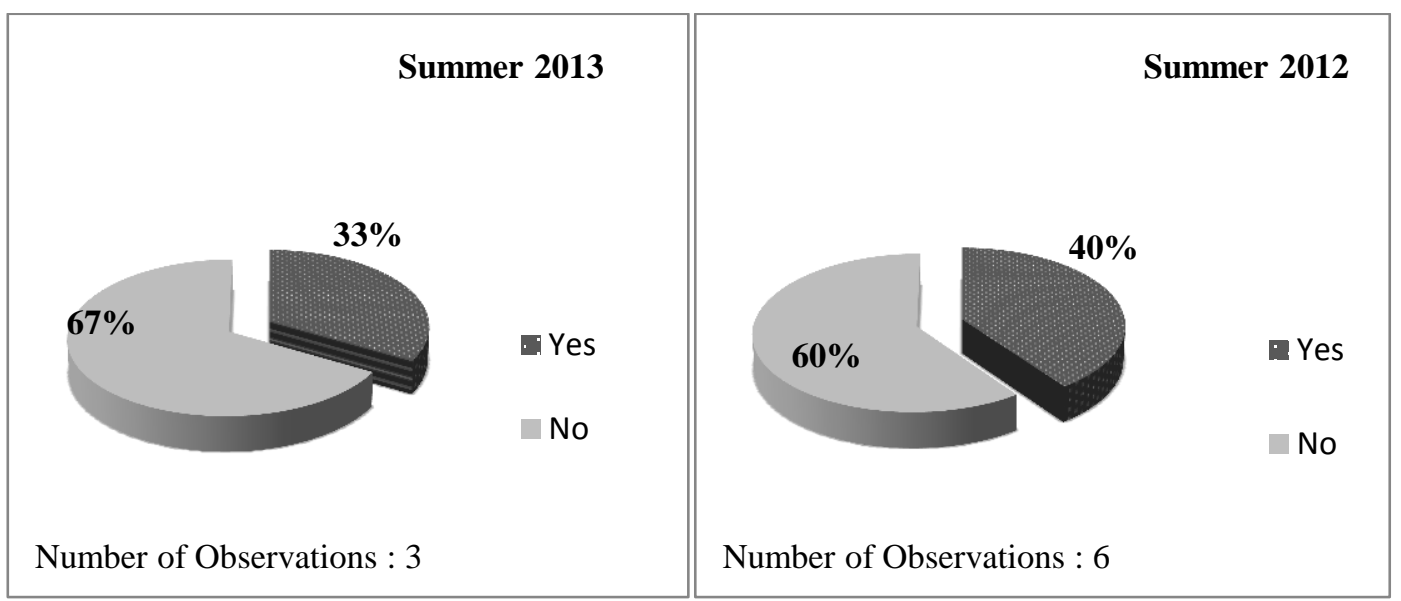

Figure 4-6 Comparison between "aggregate falling into adjacent bins while loading" in 2012 and 2013 


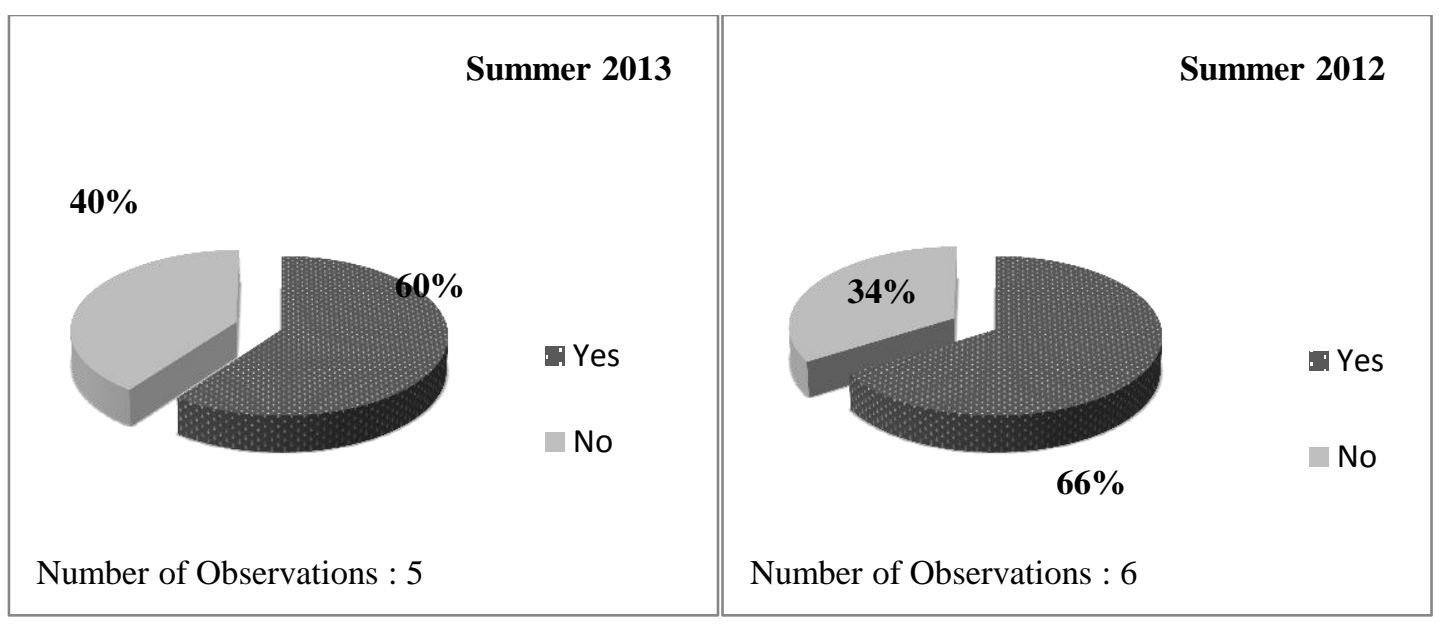

Figure 4-7 Comparison between spillage from conveyors in 2012 and 2013

\section{SURFACE PREPARATION}

Table 4-2 presents the summary of the surface preparation evaluation in summer 2012 and 2013 with high level of confidence in data. The overall rating for summer 2012 was moderate. This rating indicates that $50 \%$ to $75 \%$ of the measurable criteria have good performances. The overall rating for summer 2013 was good and it indicates more than $75 \%$ of the measurable criteria had a good performance rating (See Figure 4-8).

The remainder of the criteria had either a moderate rating, or they were not able to be rated. For example, the type of surface distresses were evaluated, however, these were corrected prior to paving so there was no rating for this field.

In Figure 4-9 and 4-10, "Existing surface being dry" and "surface being clean before paving" were presented for this category. The percentage of surface dryness and cleanness were depicted. For example, out of 45 observations in summer 2012, 67 percent of the time the surface was dry prior to paving. This led to a moderate performance rating. However, Out of 51 observations in summer 2013, 90 percent of the time the surface was dry. As a result, moderate performance in summer 2012 increase to good performance for summer 2013. 
Table 4-2: Summary of surface preparation observations

\begin{tabular}{|c|c|c|c|c|c|c|c|}
\hline & \multirow[b]{2}{*}{ Guidance* } & \multicolumn{3}{|c|}{ Summer 2012} & \multicolumn{3}{|c|}{ Summer 2013} \\
\hline & & $\begin{array}{c}\text { Total } \\
\text { Observations }\end{array}$ & $\begin{array}{l}\text { Confidence } \\
\text { in Data }\end{array}$ & Performance & $\begin{array}{c}\text { Total } \\
\text { Observations }\end{array}$ & $\begin{array}{l}\text { Confidence } \\
\text { in Data }\end{array}$ & Performance \\
\hline Surface Preparation & & & Good & Moderate & & Good & Good \\
\hline Surface type & 2,3 & 89 & Good & - & 54 & Good & - \\
\hline Weather temp & $1,2,3$ & 19 & Moderate & - & 40 & Good & - \\
\hline Template correction & $1,2,3,5$ & 75 & Good & - & 53 & Good & - \\
\hline Correction type & $2,3,5$ & 61 & Good & - & 28 & Good & - \\
\hline Surface distresses & 2,3 & 39 & Good & - & 53 & Good & - \\
\hline Drainage & 2,3 & 7 & Poor & Poor & 22 & Good & Moderate \\
\hline Surface clean & $2,3,5$ & 40 & Good & Good & 52 & Good & Good \\
\hline Surface swept & $2,3,5$ & 39 & Good & Good & 44 & Good & Good \\
\hline Surface dry & $2,3,5$ & 45 & Good & Moderate & 51 & Good & Good \\
\hline
\end{tabular}

1. USAE COE 2002

2. WVDOH Road and bridge 2010

3. WVDOH Field Tech, 2013

5. WVDOH Construction Manual, 2002

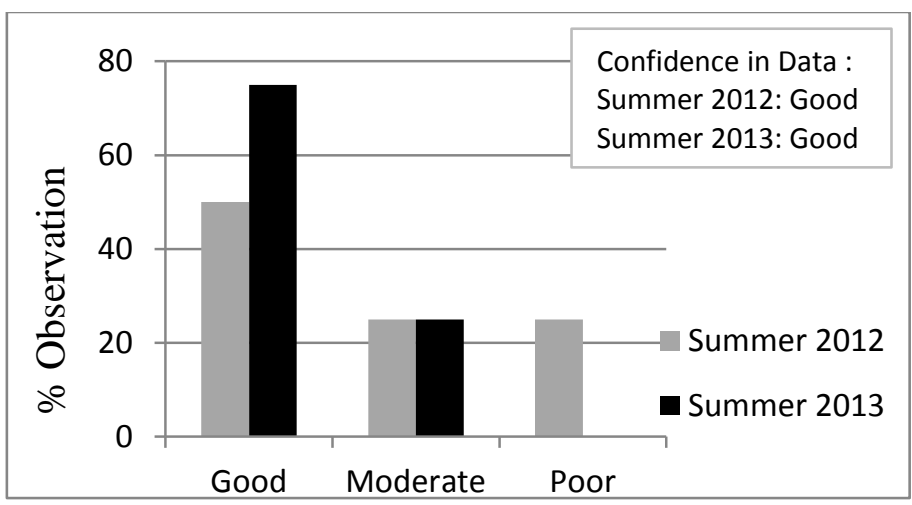

Figure 4-8 Surface preparation performances in summer 2012 and 2013 

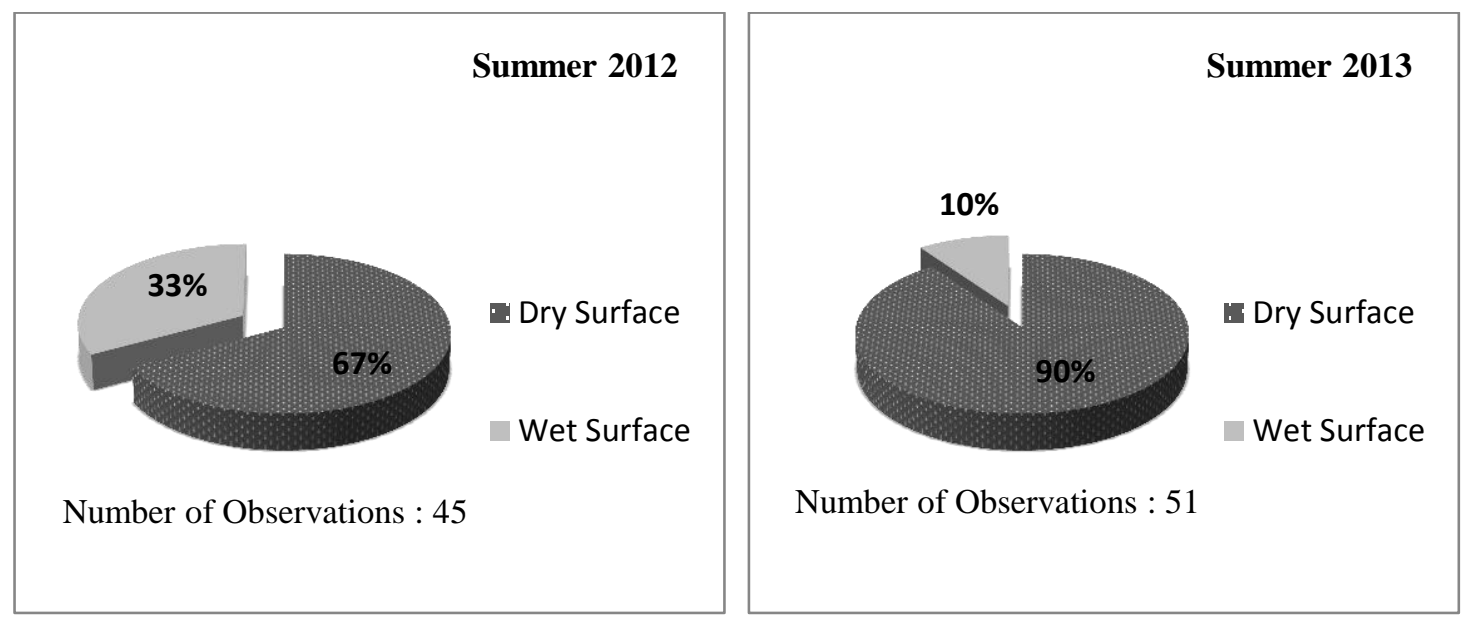

Figure 4-9 Comparison between surface being dry before paving in 2012 and 2013
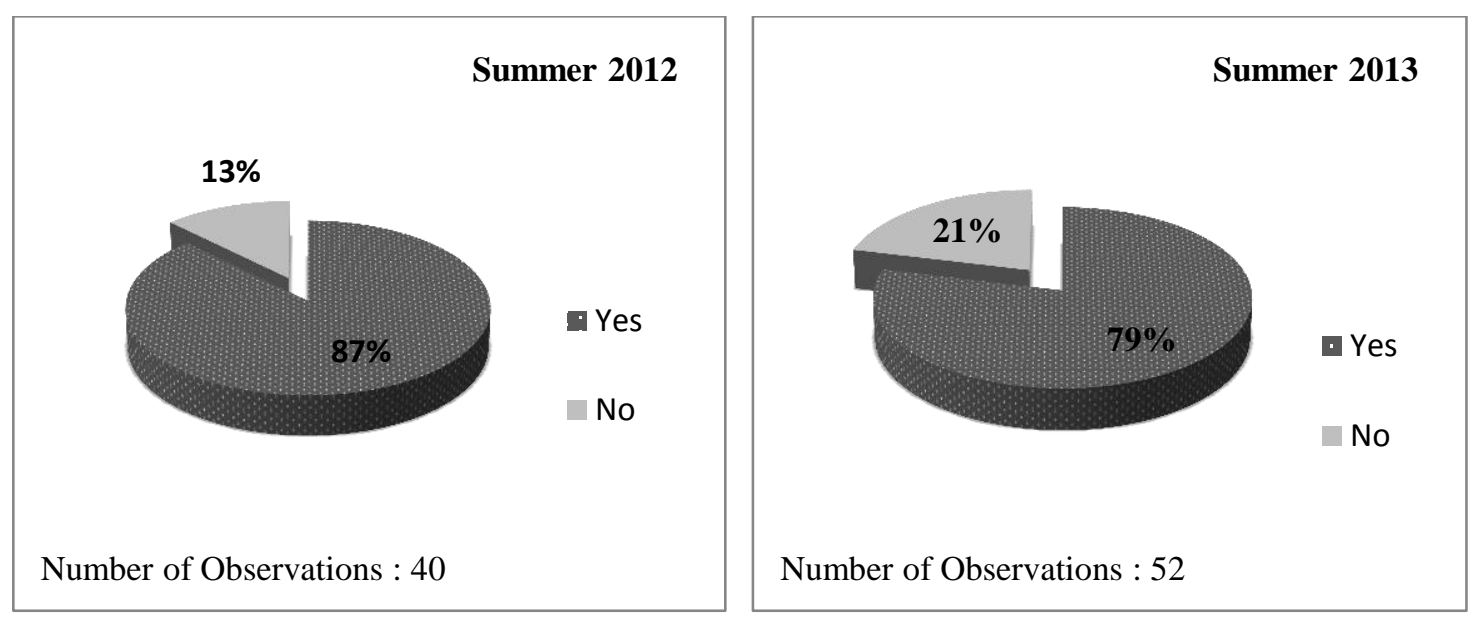

Figure 4-10 Comparison between surface being clean before paving in 2012 and 2013

\section{HAULING}

The ratings for hauling are summarized in Table 4-3. Hauling was rated as moderate and good for summer 2012 and 2013 respectively. Figure 4-11 shows an increase in hauling performance from 2012 to 2013 . However, there was a low level of confidence in some of the observations. It should be noted that the observation was done for 10 consecutive trucks. Two categories were selected for further analysis and they were presented in Figure 4-12 and 4-13 
Table 4-3: Summary of hauling observations at the mix plant

\begin{tabular}{|c|c|c|c|c|c|c|c|}
\hline & \multirow[b]{2}{*}{$\underset{*}{\text { Guidance }}$} & \multicolumn{3}{|c|}{ Summer 2012} & \multicolumn{3}{|c|}{ Summer 2013} \\
\hline & & $\begin{array}{c}\text { Total } \\
\text { Observations }\end{array}$ & $\begin{array}{l}\text { Confidence in } \\
\text { Data }\end{array}$ & Performance & $\begin{array}{c}\text { Total } \\
\text { Observations }\end{array}$ & $\begin{array}{l}\text { Confidence } \\
\text { in Data }\end{array}$ & Performance \\
\hline Hauling & & & Poor & Moderate & & Poor & Good \\
\hline Truck bed clean & $1,2,3,4,5$ & 7 & Poor & Moderate & 3 & Poor & Moderate \\
\hline Tailgate checked & 3,4 & 2 & Poor & - & - & - & - \\
\hline Truck mechanical problem & $1,3,4,5$ & 2 & Poor & - & - & - & - \\
\hline Release agent used & $1,2,3,4,5$ & 11 & Moderate & Good & 2 & Poor & Good \\
\hline Release agent type & $1,2,3,4,5$ & 4 & Poor & - & - & - & - \\
\hline Excess release agent drained & $1,2,3,4,5$ & 3 & Poor & - & - & - & - \\
\hline Loading sequence & $2,3,4,5$ & 5 & Poor & Poor & 2 & Poor & Moderate \\
\hline Tarping & $1,2,3,4,5$ & 11 & Good & Good & 3 & Poor & Good \\
\hline $\begin{array}{l}\text { Asphalt temperature in the } \\
\text { truck }\end{array}$ & $1,3,5$ & 5 & Good & Poor & - & - & - \\
\hline Loading tickets picked up & 3 & 6 & Good & Good & 3 & Moderate & Good \\
\hline Trucks leave immediately & 2 & 7 & Moderate & Moderate & 3 & Moderate & Good \\
\hline $\begin{array}{l}\text { 1. USAE COE } 2002 \\
\text { 2. WVDOH Road and brid } \\
\text { 3. WVDOH Field Tech, } 20 \\
\text { 4. WVDOH Asphalt Plant } \\
\text { 5. WVDOH Construction }\end{array}$ & $\begin{array}{l}10 \\
2013 \\
\text { al, } 2002\end{array}$ & & & & & & \\
\hline
\end{tabular}




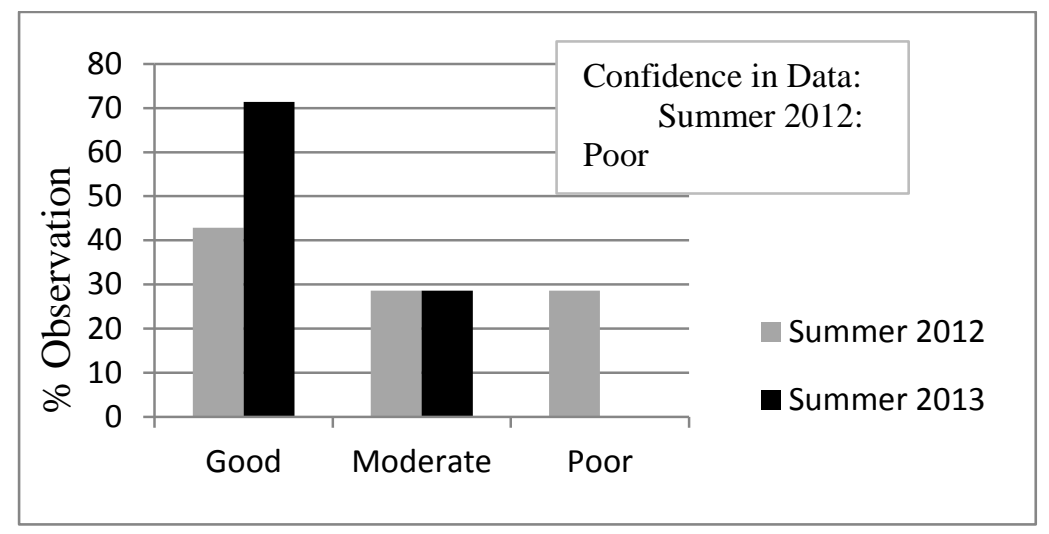

Figure 4-11 Hauling performances in summer 2012 and 2013

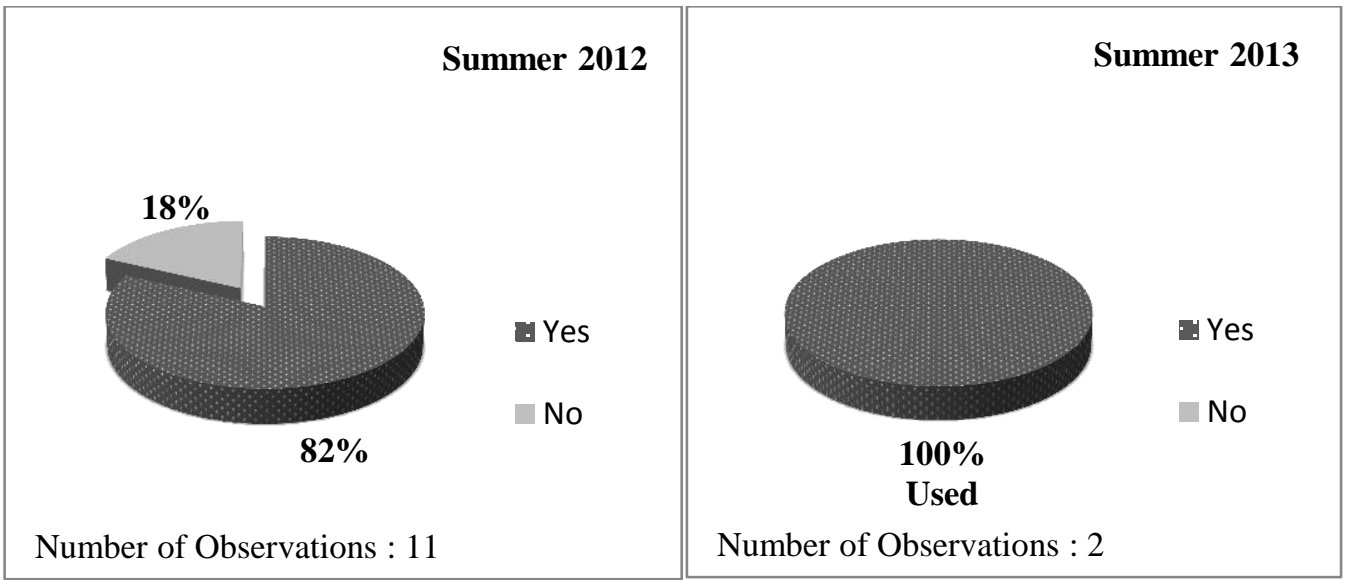

Figure 4-12 Comparison between proper release agent used in trucks in 2012 and 2013

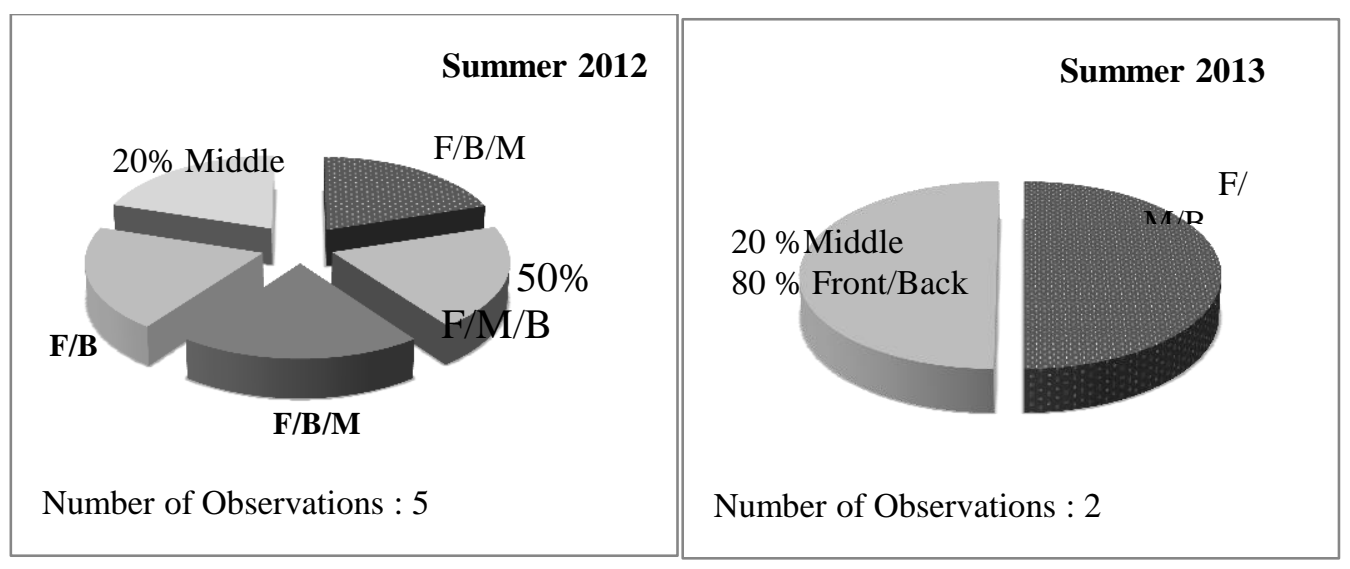

Figure 4-13 Comparison between loading sequences for trucks in 2012 and 2013 


\section{PLACEMENT}

Table 4-4 presents a summary of the placement of asphalt concrete. This category resulted in the largest amount of information received. Confidence in the data was good, due to the large amount of information provided. Review and analysis of the data for summer 2012 led to an overall performance rating of poor for the placement. This was based on the fact that only $17 \%$ of the observed criteria were rated good, while $67 \%$ was rated as poor. The overall performance rating for the placement in summer 2013 was increased but also rated as poor. This was based on the fact that $43 \%$ of the observed criteria were rated good and $18 \%$ were rated moderate, while only $36 \%$ was rated as poor Figure 4-14.

Twelve subcategories were selected for further analysis and they were presented in Figure 415 through 4-26. The percentages of placement observations were compared for each subcategory.

For example, Figure 4-15 shows that only $8 \%$ of tack coat distributed uniformly across the surface in 2012. This increased to $14 \%$ for 2013. However both of them were rated as poor performance. All figures present the percentage of construction practices problem for placement. 
Table 4-4: Summary of placement observations

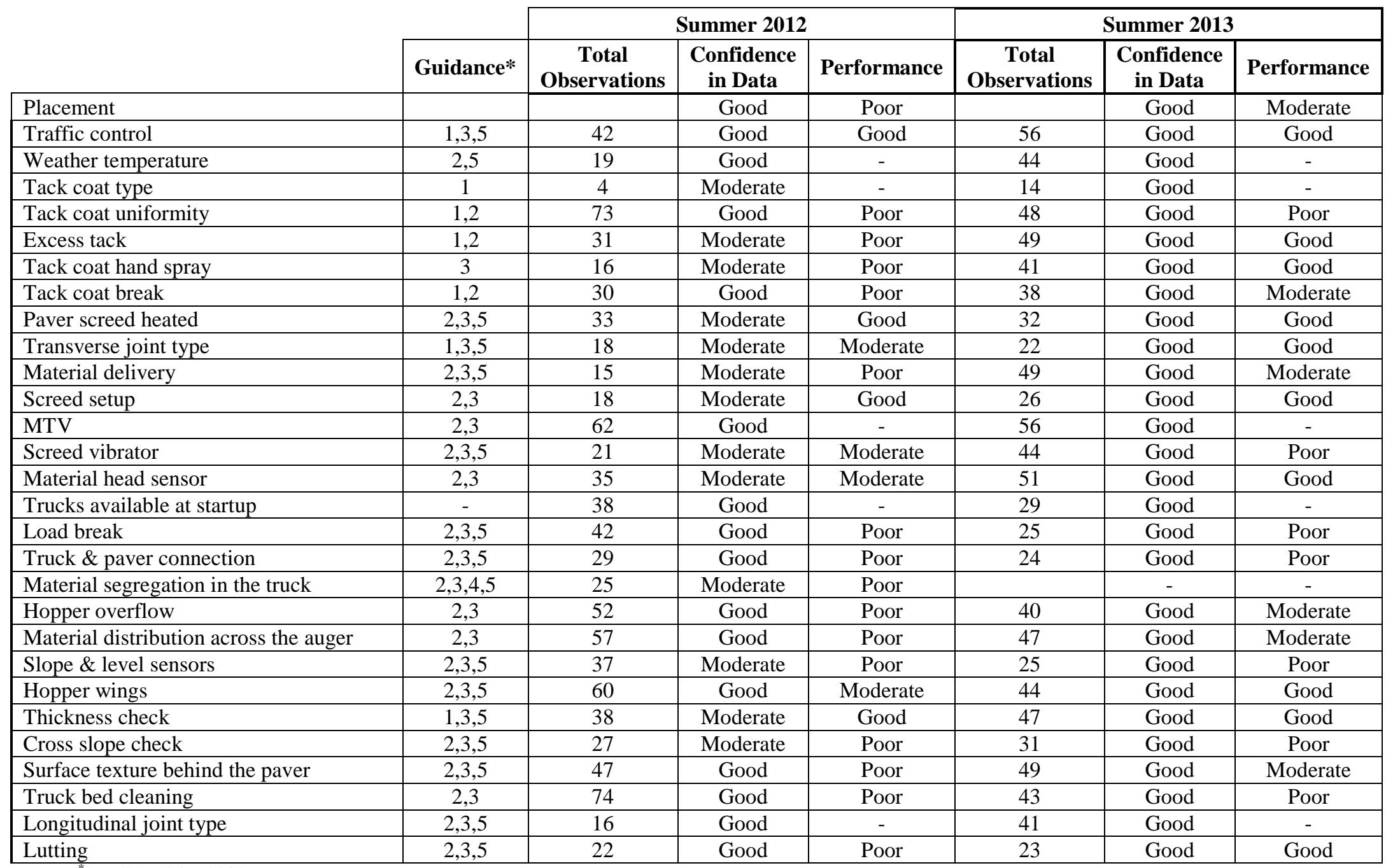

1. USAE COE 2002

2. WVDOH Road and bridge 2010

3. WVDOH Field Tech, 2013

4. WVDOH Asphalt Plant Tech, 2013

5. WVDOH Construction Manual, 2002 


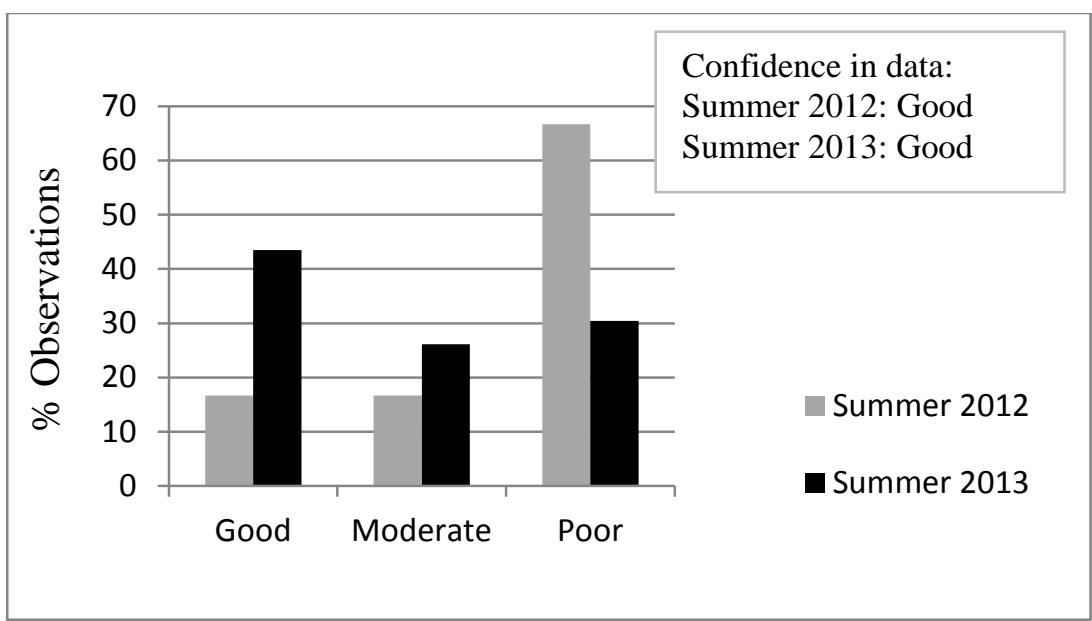

Figure 4-14 Placement performances in summer 2012 and 2013

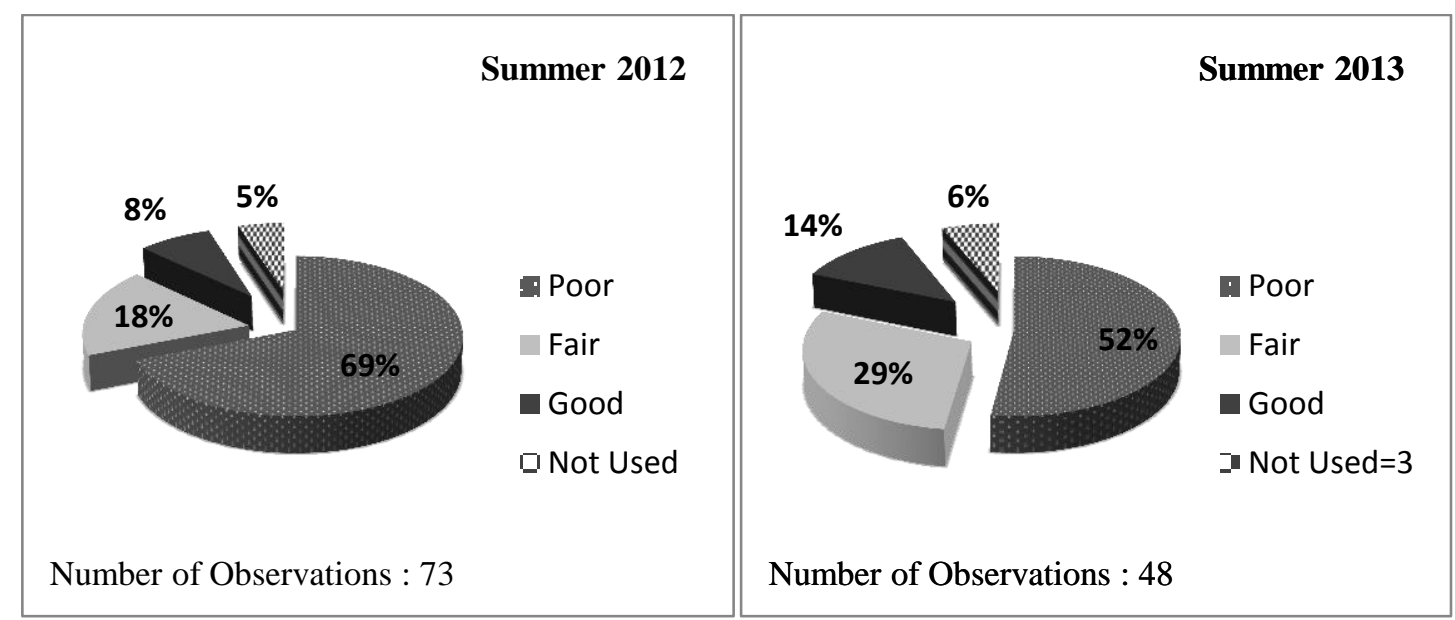

Figure 4-15 Comparison between tack coat uniformity in 2012 and 2013

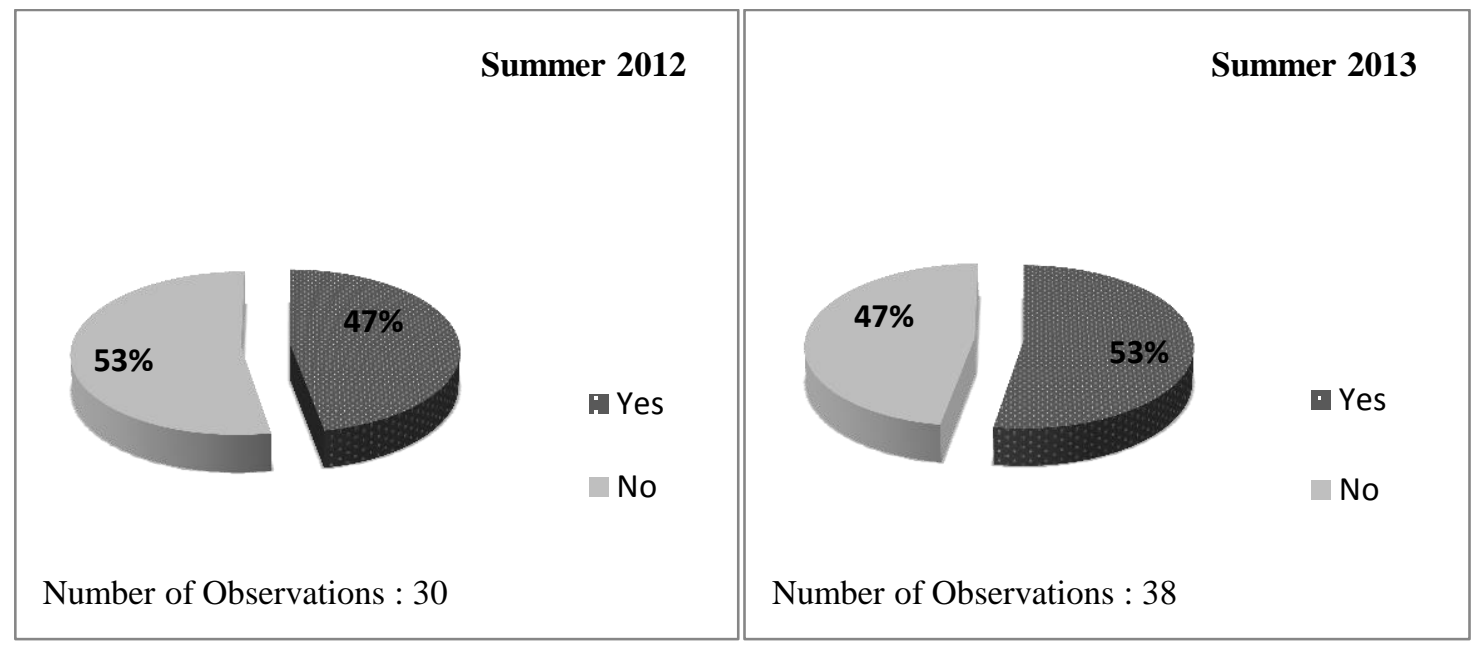

Figure 4-16 Comparison between tack coat break in 2012 and 2013 

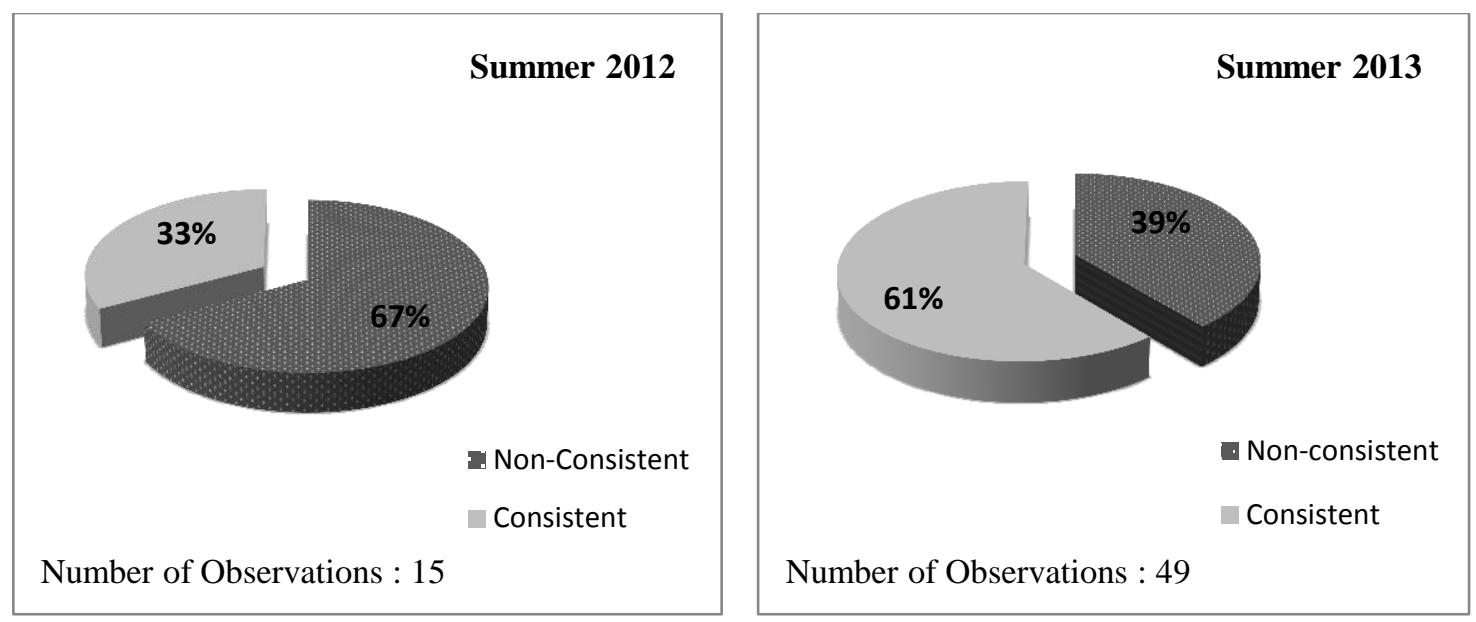

Figure 4-17 Comparison between material delivery in 2012 and 2013
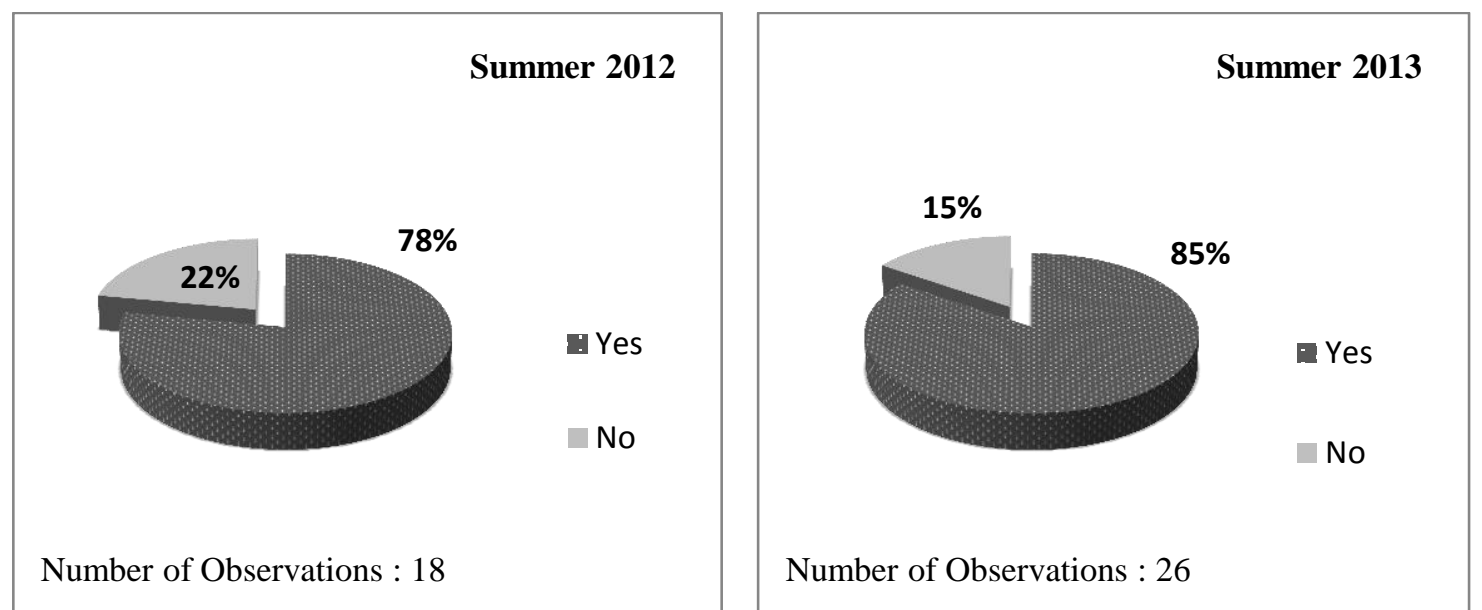

Figure 4-18 Comparison between screed setup at beginning of paving in 2012 and 2013
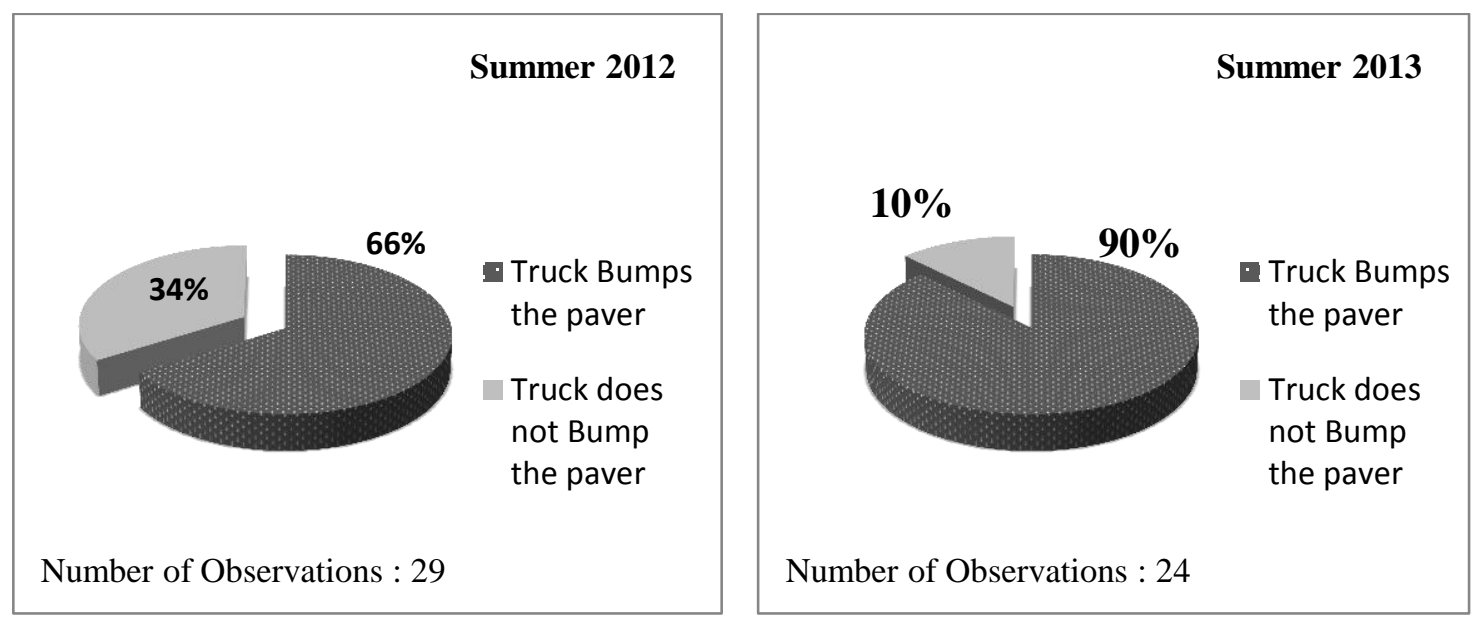

Figure 4-19 Comparison between truck and paver connection in 2012 and 2013 


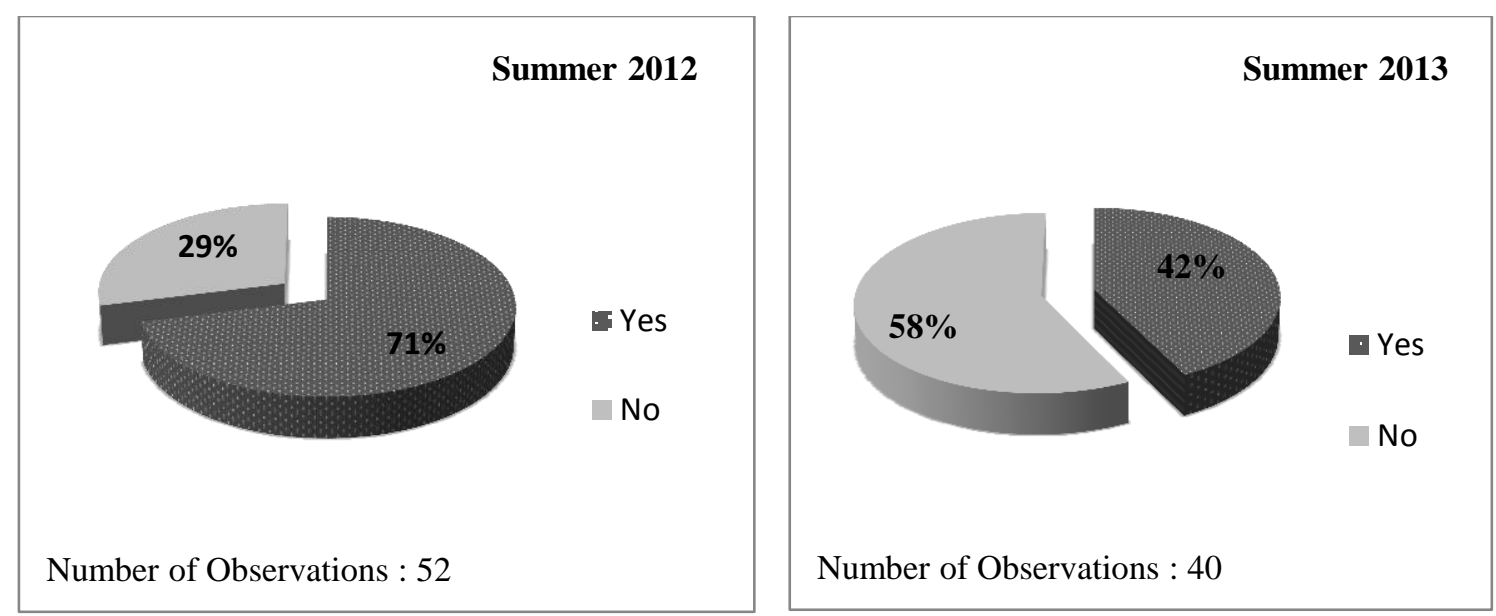

Figure 4-20 Comparison between hopper overflow in 2012 and 2013
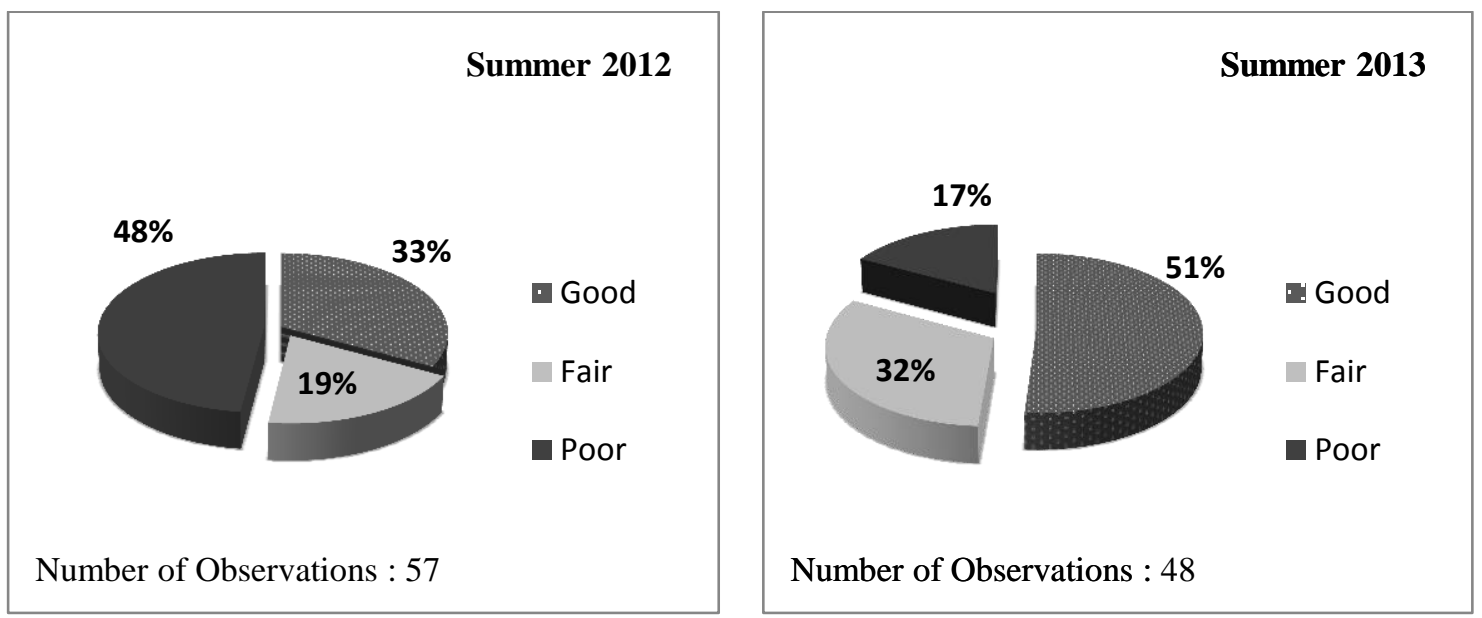

Figure 4-21 Comparison between material distribution across the auger in 2012 and 2013
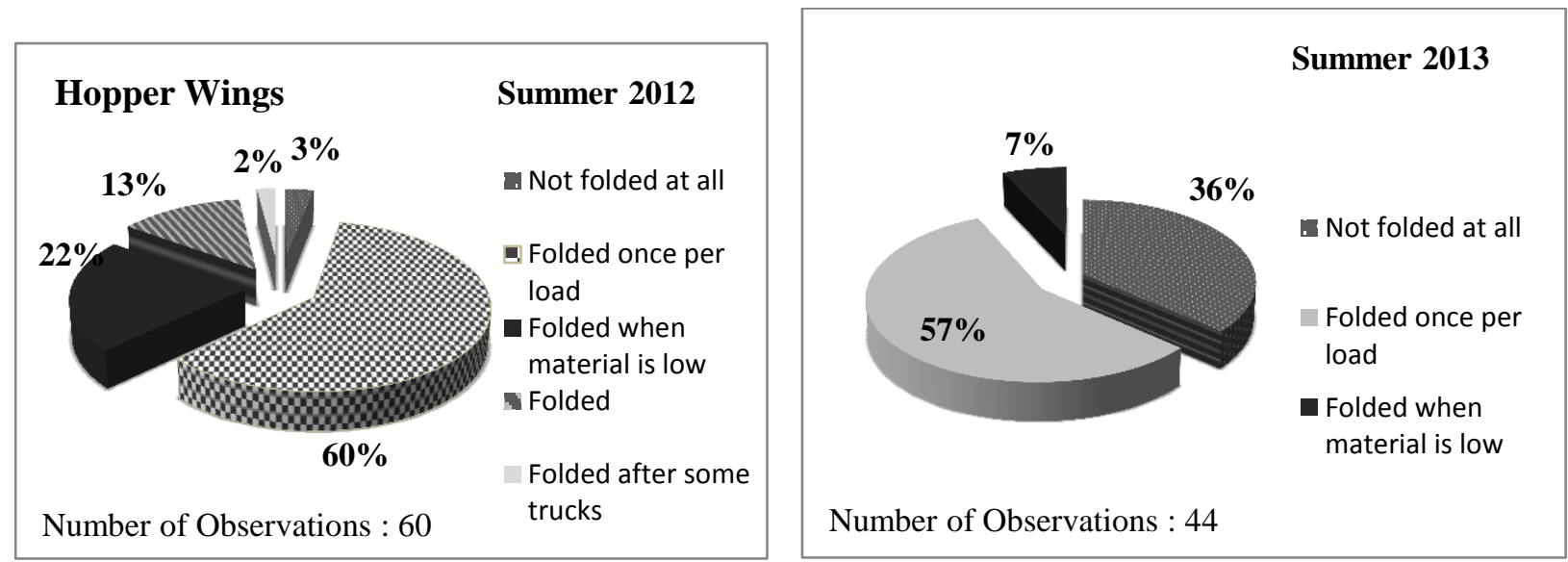

Figure 4-22 Comparison between hopper wings in 2012 and 2013 

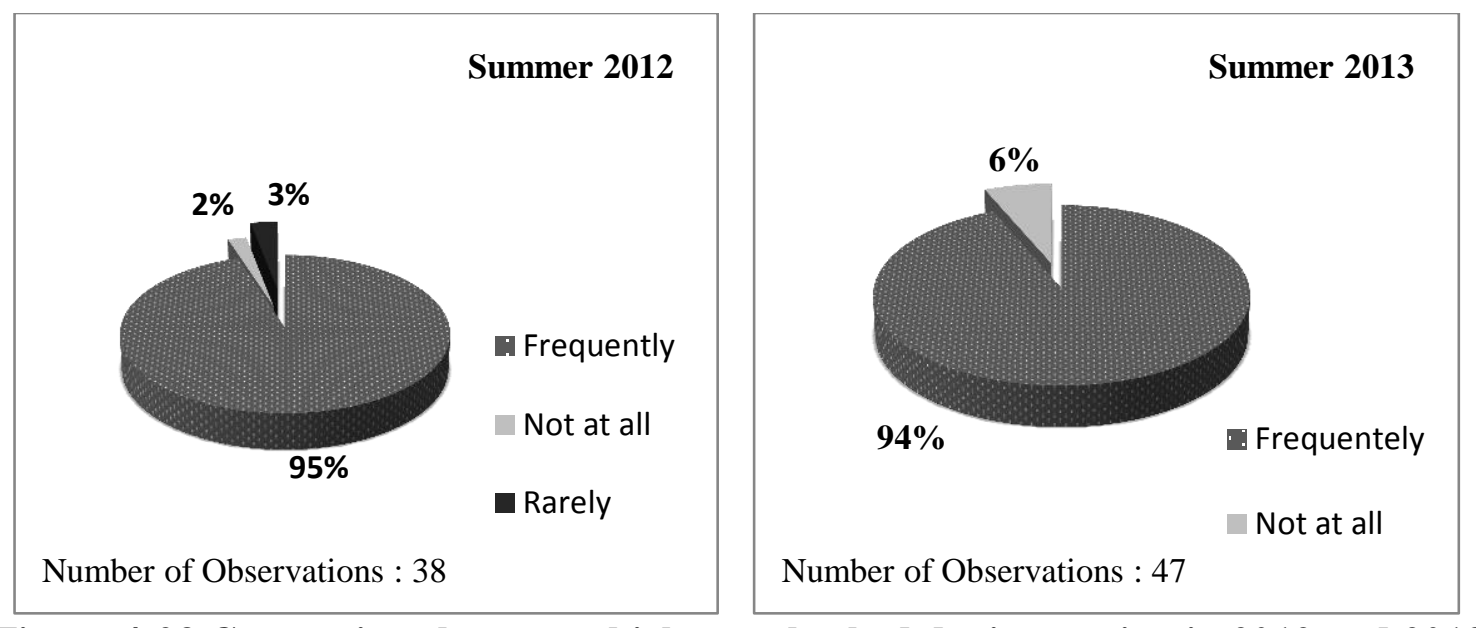

Figure 4-23 Comparison between thickness checked during paving in 2012 and 2013
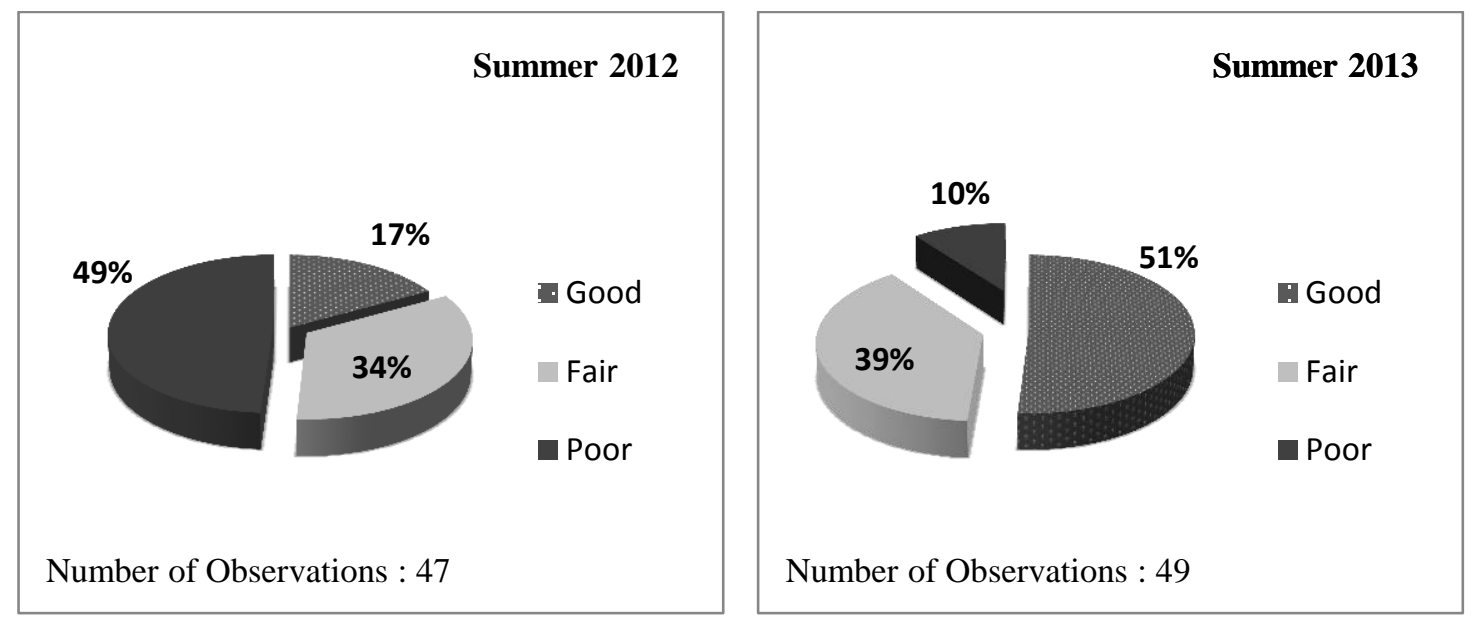

Figure 4-24 Comparison between surface texture behind the paver in 2012 and 2013
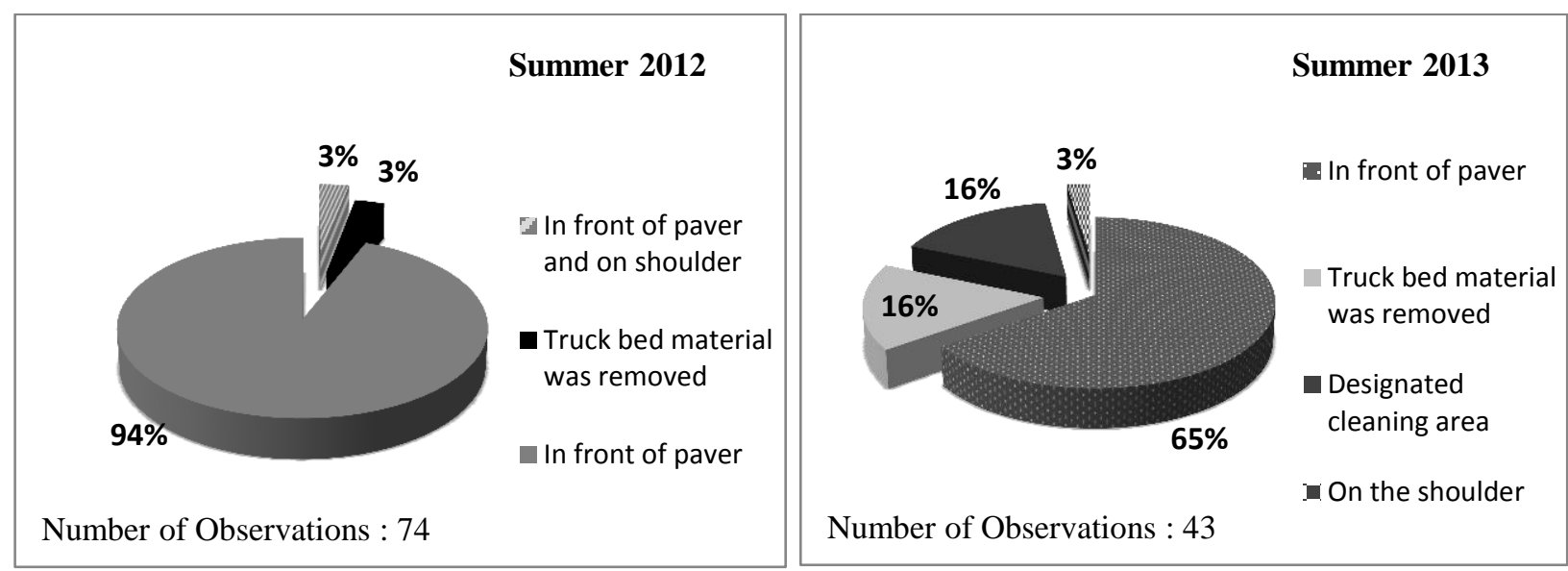

Figure 4-25 Comparison between truck bed cleaning after loading in 2012 and 2013 

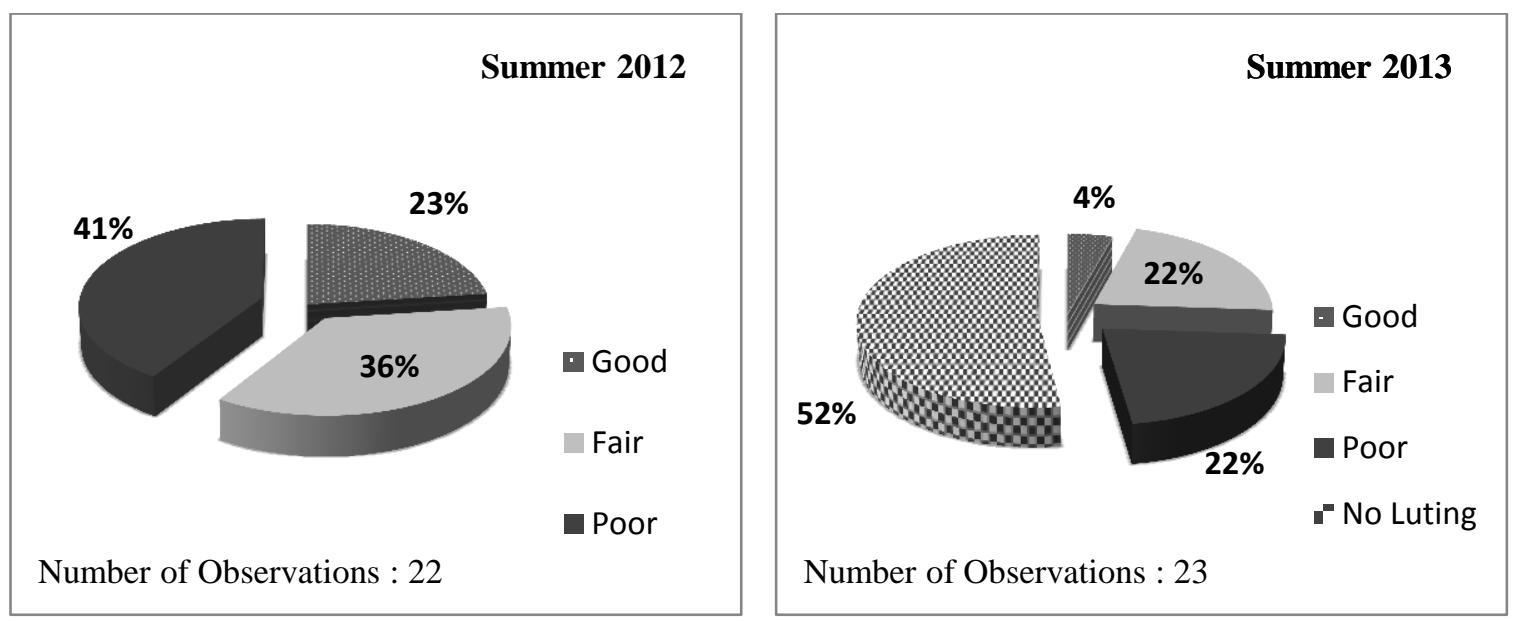

Figure 4-26 Comparison between luting condition in 2012 and 2013

\section{COMPACTION}

The compaction operation was evaluated as general compaction observations and rolling patter. The rolling pattern was evaluated in more detail due to the importance of compaction on the performance of an asphalt pavement.

\section{GENERAL COMPACTION OBSERVATIONS}

Table 4-5 presents a summary of the compaction process. Compaction practices were rated as moderate for summer 2012. Due to the number of observations and the quality of the ratings the confidence in the data was rated as good. Most of the subcategories in Table 4-5 were rated as good. As a result, the evaluation of performance in summer 2013 was rated as good. All of the subcategories are rated as good for 2012, except the "transverse joint compaction" was rated as poor and "stopping on hot mat" was rated as moderate. Figure 4-28 through 4-31 presents the percentage of construction practices problem for compaction. 
Table 4-5: Summary of compaction observations

\begin{tabular}{|c|c|c|c|c|c|c|c|}
\hline & & \multicolumn{3}{|c|}{ Summer 2012} & \multicolumn{3}{|c|}{ Summer 2013} \\
\hline & Guidance* & $\begin{array}{c}\text { Total } \\
\text { Observations }\end{array}$ & $\begin{array}{l}\text { Confidence } \\
\text { in Data }\end{array}$ & Performance & $\begin{array}{c}\text { Total } \\
\text { Observations }\end{array}$ & $\begin{array}{c}\text { Confidence } \\
\text { in Data }\end{array}$ & Performance \\
\hline Compaction & & & Good & Moderate & & Good & Good \\
\hline Roller liquid leak & 1,3 & 40 & Good & Good & 54 & Good & Good \\
\hline Roller nozzles & 3 & 44 & Good & Good & 56 & Good & Good \\
\hline Roller scrapers & 3 & 49 & Good & Good & 56 & Good & Good \\
\hline Drive drum forward & 2,3 & 48 & Good & Good & 50 & Good & Good \\
\hline Stopping on hot mat & 2 & 62 & Good & Poor & 53 & Good & Moderate \\
\hline Roller drums kept moist & 3 & 46 & Good & Good & 55 & Good & Good \\
\hline Visible defects at the end & 2 & 66 & Good & Poor & 50 & Good & Good \\
\hline $\begin{array}{l}\text { Transverse joint } \\
\text { compaction }\end{array}$ & $2,3,5$ & 44 & Good & Poor & 28 & Good & Poor \\
\hline $\begin{array}{l}\text { Longitudinal joint } \\
\text { compaction }\end{array}$ & $2,3,5$ & 44 & Good & Poor & 27 & Good & Good \\
\hline
\end{tabular}

1. USAE COE 2002

2. WVDOH Road and bridge 2010

3. WVDOH Field Tech, 2013

4. WVDOH Asphalt Plant Tech, 2013

5. WVDOH Construction Manual, 2002 


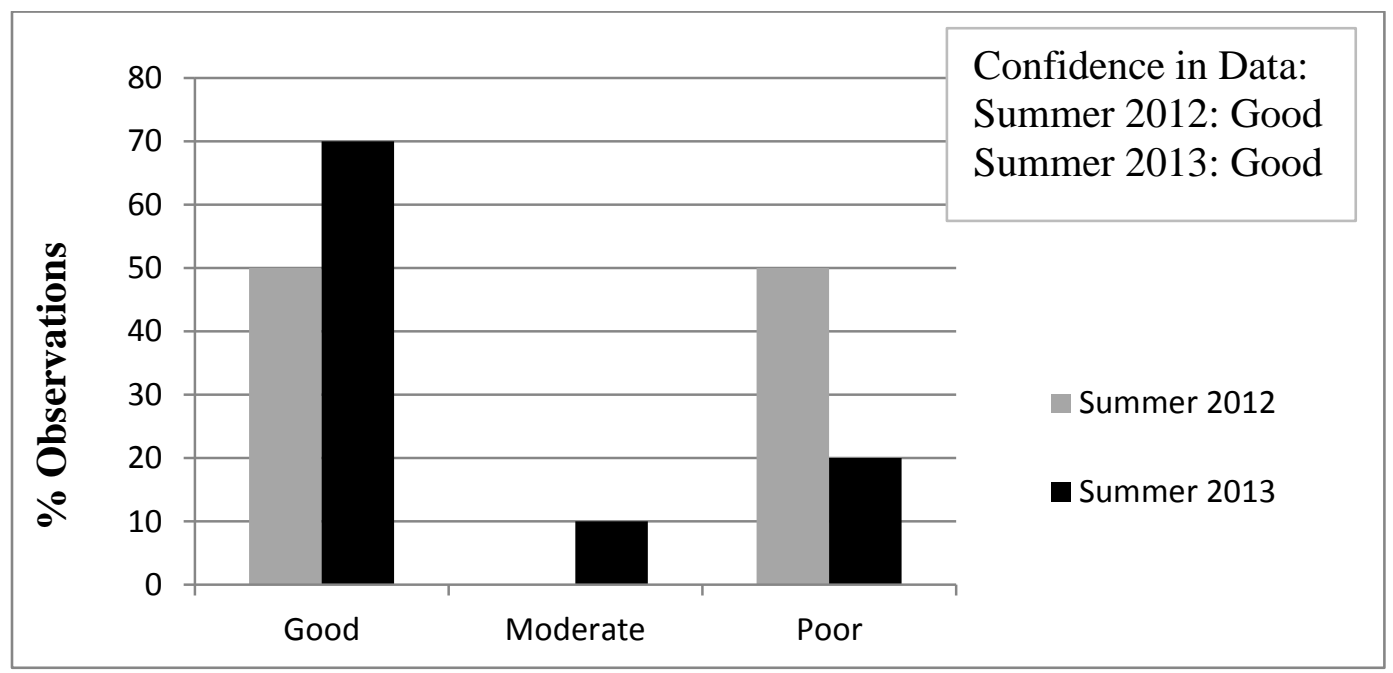

Figure 4-27 Compaction performances in summer 2012 and 2013

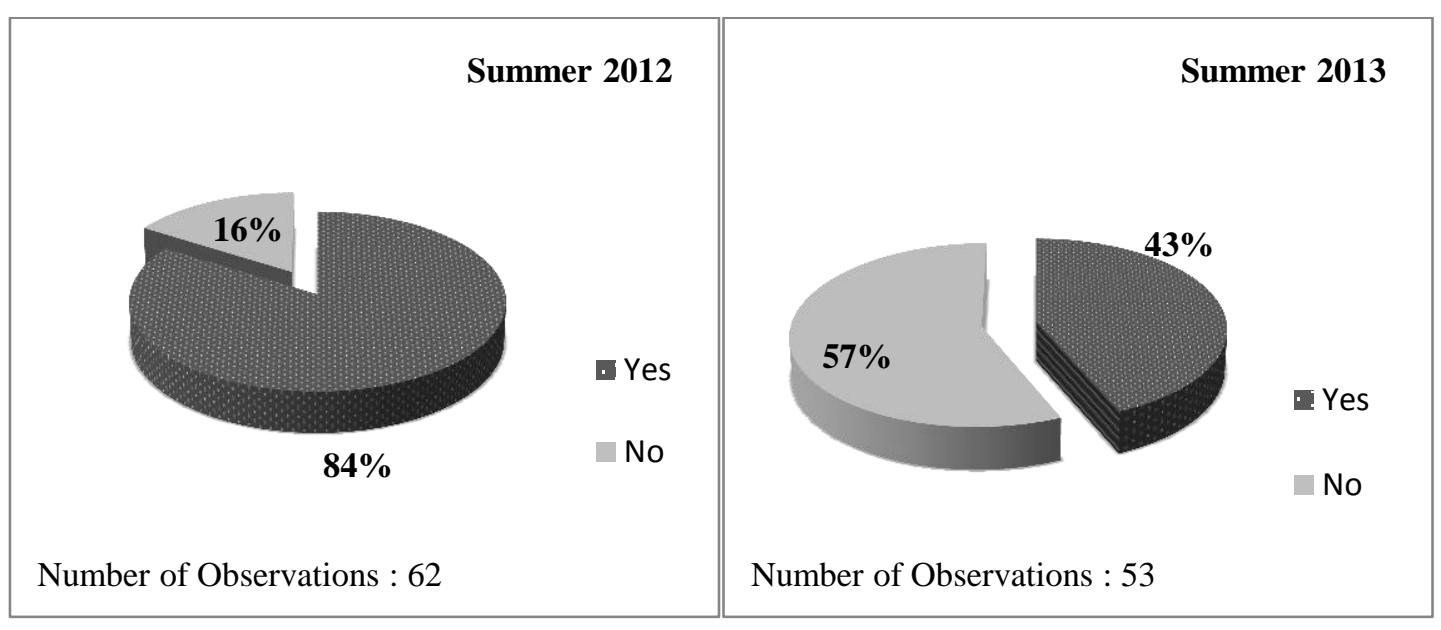

Figure 4-28 Comparison between stopping on hot material in 2012 and 2013 


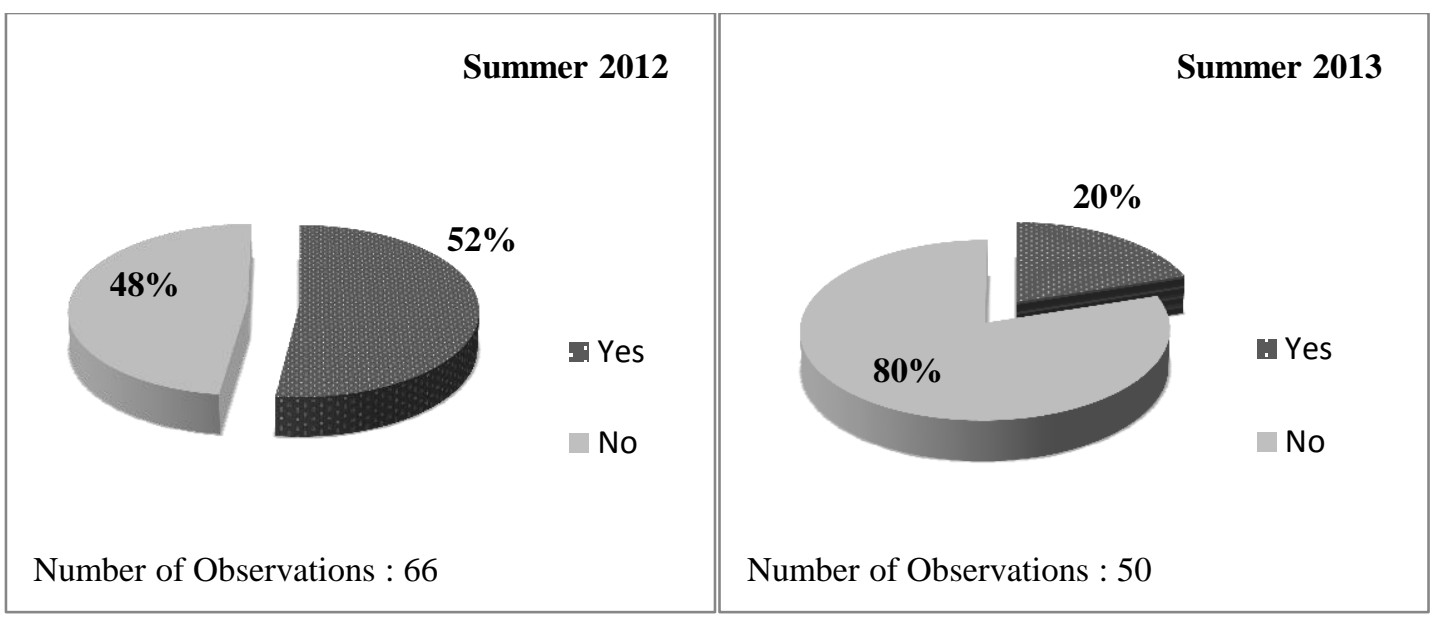

Figure 4-29 Comparison between visible roller marks after compaction in 2012 and 2013

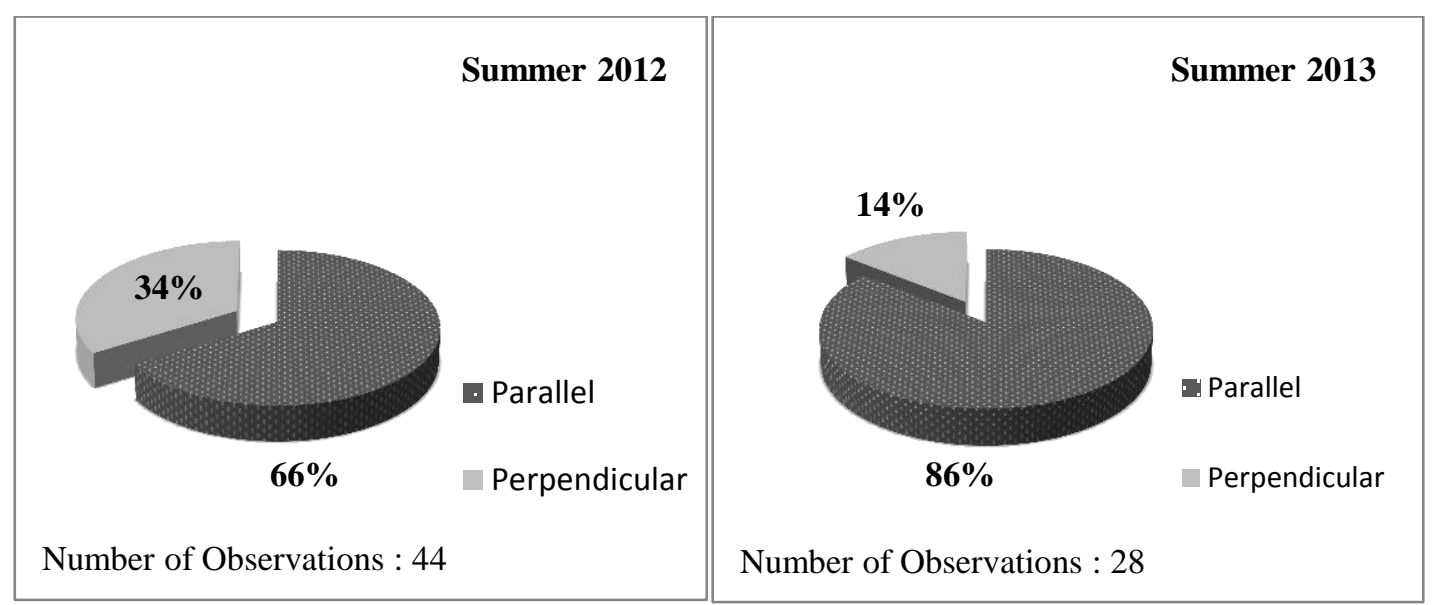

Figure 4-30 Comparison between transverse joint compaction in 2012 and 2013

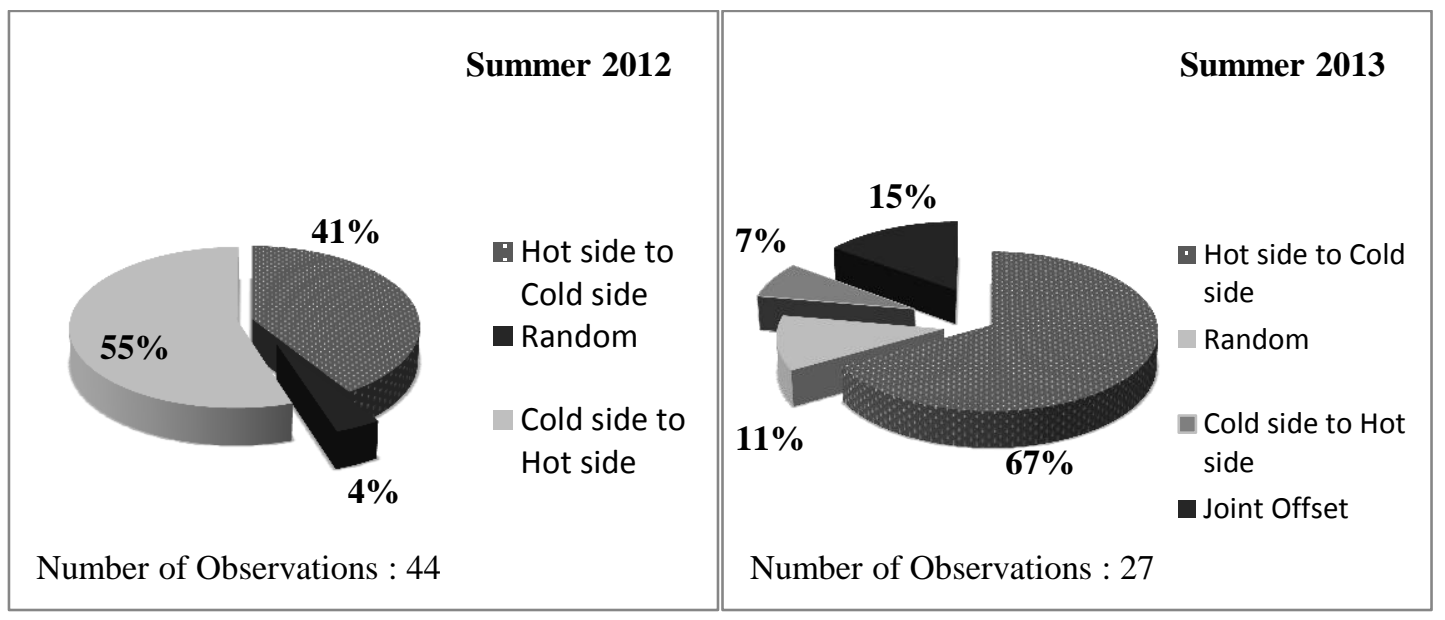

Figure 4-31 Comparison between Longitudinal joint compactions in 2012 and 2013 


\section{ROLLING PATTERN}

As is mentioned in last chapter, the roller passes were observed in regardless of breakdown, intermediate and finish rolling process. The numbers of passes by first rollers were presented in Table 4-6. This table includes the data observed by co-ops and cameras. The camera pictures and co-ops field observations mostly comply with each other for first roller (6 out of 9).

Consequently, the co-ops field observations were accepted as being reliable.

Overall 24 out of 28 (86\%) rolling pattern observations were uniform by first rollers. This indicates the first roller passed all over the lane equally in most of the projects, so the lane compacted uniformly.

The numbers of passes by second rollers are presented in Table 4-7. There were no suitable camera records of the second roller, so only co-op observations were available. Of the 15 observed rolling patterns $12(80 \%)$ were found to be uniform. This indicates the second rollers passed all over the lane equally in most of the projects, so the lane compacted uniformly. Consequently, the overall performance rating for the rolling patterns in summer 2013 is rated as good. 
Table 4-6 Number of passes for first rollers

\begin{tabular}{|c|c|c|c|}
\hline $\begin{array}{l}\text { ID } \\
\text { No }\end{array}$ & $\begin{array}{l}\text { No. of passes recorded } \\
\text { by camera }\end{array}$ & $\begin{array}{l}\text { No. of passes reported } \\
\text { by co-ops }\end{array}$ & $\begin{array}{l}\text { Rolling Pattern } \\
\text { Uniformity }\end{array}$ \\
\hline 150 & - & 8,6 passes (left, right) & Non-Uniform \\
\hline 151 & $5,1,1$ passes (left, middle, right) & 5,6 passes (left, right) & Uniform \\
\hline 153 & 4,1,4 passes (left, middle, right) & 4,1,4 passes (left, middle, right) & Non-Uniform \\
\hline 155 & $1,1,1$ passes (left, middle, right) & $1,1,1$ passes (left, middle, right) & Uniform \\
\hline 156 & - & $1,2,2$ passes (left, middle, right) & Uniform \\
\hline 157 & $\begin{array}{c}\text { 6,7,1 - 6,7,1 passes (left, right, } \\
\text { shoulder) }\end{array}$ & $\begin{array}{c}\text { 7,7,1 - 7,7,1 passes (left, right, } \\
\text { shoulder) }\end{array}$ & Uniform \\
\hline 159 & - & 6,6,1 passes (left, right, shoulder) & Uniform \\
\hline 160 & - & $5,5-7,6$ passes (left, right) & Uniform \\
\hline 161 & - & 5,5-6,6 passes (left, right) & Uniform \\
\hline 164 & - & $6,7-6,7-6,5$ passes (left, right) & Uniform \\
\hline 165 & 9,4,5 (left, middle, right) & 9,10 passes (left, right) & Uniform \\
\hline 169 & - & 4,3 passes (left, right) & Uniform \\
\hline 173 & $\begin{array}{c}4,6,3,4 \text { passes (in } 4 \text { rolling for a } \\
\text { lane) }\end{array}$ & $\begin{array}{l}\text { 4, 6, 3, } 4 \text { passes (In } 4 \text { rolling for a } \\
\text { lane) }\end{array}$ & Non-Uniform \\
\hline 174 & 4,4,2 passes (left, right, joint) & 4,4,2 passes (left, right, joint) & Uniform \\
\hline 178 & 8,8 passes (left, right) & 8,8 passes (left, right) & Uniform \\
\hline 179 & - & 5,4 (left, right) & Uniform \\
\hline 197 & 4,3 passes (left, right) & 4,3 passes (left, right) & Uniform \\
\hline 198 & - & 2,3 passes (left, right) & Uniform \\
\hline 199 & - & 3,2 passes (left, right) & Uniform \\
\hline 200 & - & 3,2 passes (left, right) & Uniform \\
\hline 201 & - & $3,3,1-3,2,2$ passes (left, middle, right) & Non-Uniform \\
\hline 203 & - & 4,4 passes (left, right) & Uniform \\
\hline 204 & - & 4,4 passes (left, right) & Uniform \\
\hline 207 & - & 6,6,1 passes (left, right, shoulder) & Uniform \\
\hline 208 & - & 6,6,1 passes (left, right, shoulder) & Uniform \\
\hline 209 & - & $5,6-7,6$ passes (left, right) & Uniform \\
\hline 210 & - & 7,6 - 7-6 passes (left, right) & Uniform \\
\hline 211 & - & 7,6 passes (left, right) & Uniform \\
\hline
\end{tabular}

* Separated observations are defined by “-”. 
Table 4-7 Number of passes for second rollers

\begin{tabular}{|c|c|c|}
\hline ID No & No. of passes reported by co-ops & Rolling Pattern Uniformity \\
\hline 153 & $4,1,4$ passes (left, middle, right) & Non-Uniform \\
\hline 157 & $3,3,3-4,4,1$ passes (left, right, shoulder) & Uniform \\
\hline 159 & 6,6 passes (left, right) & Uniform \\
\hline 160 & $7,6-7,6$ passes (left, right,) & Uniform \\
\hline 161 & $6,7-7,6$ passes (left, right,) & Uniform \\
\hline 164 & $6,5-6,7-6,7$ passes (left, right) & Uniform \\
\hline 169 & 3,4 passes (left, right) & Uniform \\
\hline 175 & $2,5,5,2$ (in 4 rolling lanes) passes & Non-Uniform \\
\hline 197 & 3,4 passes (left, right) & Uniform \\
\hline 198 & 3,2 passes (left, right) & Uniform \\
\hline 200 & 3,2 passes (left, right) & Uniform \\
\hline 201 & $2,2,2-1,2,2$ passes (left, middle, right) & Non-Uniform \\
\hline 209 & $6,7-5,4$ passes (left, right) & Uniform \\
\hline 210 & $6,7-7,6$ passes (left, right) & Uniform \\
\hline 211 & 6,7 passes (left, right) & Uniform \\
\hline
\end{tabular}

\section{SHOULDER WIDENING}

Table 4-8 presents a summary of shoulder widening construction practices. There were only a ten projects in summer 2012 that involved shoulder widening and therefore there was only a moderate level of confidence in the data. However, there were only a 3 projects in summer 2013 that involved shoulder widening and therefore there was only a poor level of confidence in the data. Figure 4-32 shows the overall performances of shoulder widening were rated as moderate and good in summer 2012 and 2013 respectively. 
Table 4-8: Summary of shoulder widening observations

\begin{tabular}{|c|c|c|c|c|c|c|c|}
\hline & Guidance* & $\begin{array}{c}\text { Total } \\
\text { Observations }\end{array}$ & $\begin{array}{c}\text { Confidence } \\
\text { in Data }\end{array}$ & Performance & $\begin{array}{c}\text { Total } \\
\text { Observations }\end{array}$ & $\begin{array}{l}\text { Confidence } \\
\text { in Data }\end{array}$ & Performance \\
\hline Shoulder Widening & & & Moderate & Moderate & & Poor & Good \\
\hline Trench & & 10 & Moderate & Good & 3 & Poor & Good \\
\hline Trench bottom is clean & & 9 & Moderate & Moderate & 3 & Poor & Good \\
\hline Vegetation removed & & 9 & Moderate & Moderate & 3 & Poor & Good \\
\hline Special paver & & 10 & Moderate & Good & 3 & Poor & Good \\
\hline Mix segregation & $1,2,3$ & 9 & Moderate & Moderate & 3 & Poor & Good \\
\hline $\begin{array}{l}\text { Right roller used for } \\
\text { compaction }\end{array}$ & 2,3 & 9 & Moderate & Poor & 3 & Poor & Poor \\
\hline
\end{tabular}
1. USAE COE 2002
2. WVDOH Road and bridge 2010
3. WVDOH Field Tech, 2013
4. WVDOH Asphalt Plant Tech, 2013
5. WVDOH Construction Manual, 2002

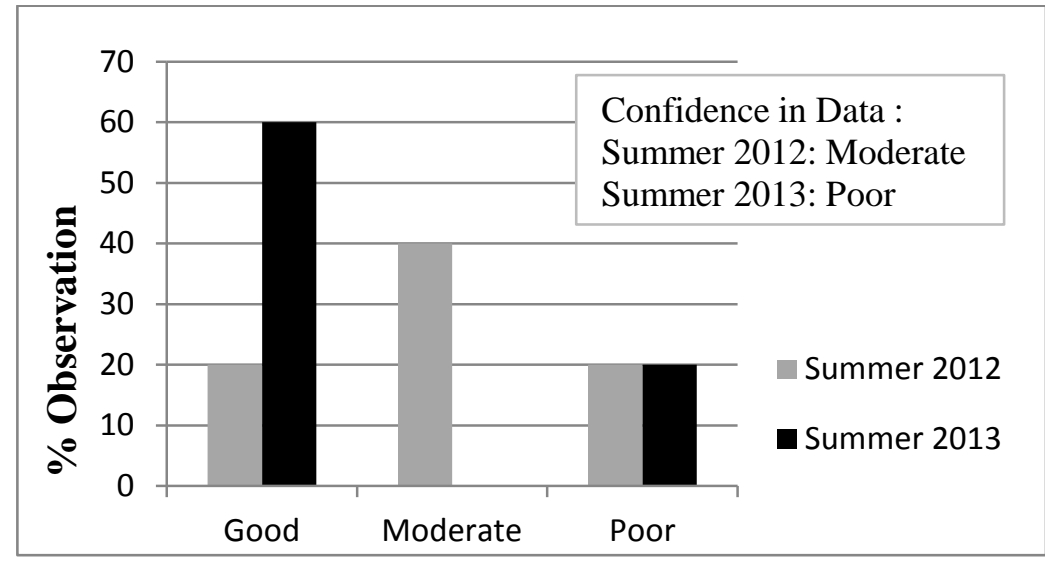

Figure 4-32 Shoulder widening performances in summer 2012 and 2013 


\section{TRUCK TRAVEL TIME AND TEMPERATURE}

Inconsistency in the material delivery rate and mix temperature has negative effects on the quality of paving. Based on the data collected in summer 2012 the average normalized difference in the travel time of the trucks was $44 \%$ which is indicative of poor performance. However, the average difference in the material delivery temperature for the observed projects was found to be $2 \%$ which is indicative of good performance. In addition, it was planned to estimate the average temperature drop during the transportation of the material to the site for each project based on the reports. However this was not accomplished because the production temperature is reported by the supplier once a day and there is evidence that shows this temperature fluctuates during the production.

Based on the data collected in summer 2013 the average normalized difference in the travel time of the trucks was $15 \%$ which is indicative of good performance. It is also the average difference in the material delivery temperature for the observed projects was found to be $3 \%$ which is indicative of good performance. Confidence in data was good for truck travel time observation in summer 2012 and 2013.

\section{TEMPERATURE DROP}

The quality of the compaction operation greatly depends on the HMA temperature. The rolling operation should be performed as quickly as possible to minimize the mat temperature drop. To evaluate the quality of the compaction operation the mat temperature was measured at three times; after placement by the paver, before compaction started, and after compaction was completed. The average surface temperature at the end of compaction was rated as good for 2012. The average surface temperature at the end of compaction was rated as moderate for summer 2013. The average temperature behind paver, before compaction started, and after compaction was completed was $288,246,177^{\circ} \mathrm{F}$. However, the great amount of temperature loss occurred before the rolling process started. This suggests either the inefficiency of the rolling operation or inadequacy of rollers available on site. 


\section{CHAPTER 5 SUMMARY}

Generally, the data collected on this project was successful in developing an understanding of the asphalt concrete pavement construction practices in West Virginia.

During summer 2013, more concentrated efforts were made to train and provide guidance to the co-ops to allow them to make the observations to the best of their ability. There was an effort to collect additional data on certain areas of the paving process, such as observations of the roller pattern. In addition, the observation recording process simplified to focus more directly on critical performance areas. Management of the co-ops also was improved. In addition, the quality of information was enhanced by shorting the time period between the observations by the co-ops and the review of the observations by the researchers. Feedback and responses were provided to the co-ops with respect to both their data collection process and their work assignment every day.

According to observations from summer 2012, plant operations comply with best management practices in most areas. However, the observations did indicate several opportunities for improvement in the hauling, placement and compaction of the asphalt concrete. On the other hand, according to observations from summer 2013, Plant operations kept its good compliance with best management practices in most areas. Moreover, the performance of hauling, surface preparation, placement and compaction of the asphalt concrete were improved. Finally, the observations for rolling pattern in summer 2013 indicate good performances that comply with best management practices.

Further research could be separated into two categories:

- Concerns with the level of confidence in the data, i.e. items with a poor confidence rating, and

- Contractor performance areas that are rated as moderate or poor. Perhaps futher monitoring could practices that should be improved.

Table 4.1 shows poor confidence in the data for several of the plant monitoring items especially in 2012. However, little effort was place on further evaluating plant observations in 2013 due to overall good performance rating for plant operation in 2012. In 2013 the only plant operation areas rated as poor were labeling of the asphalt tank with binder grade and spillage 
aggregates from the conveyors. Labeling the asphalt cement tanks is probably not an issue. Spillage from the conveyors is something that contractors should monitor and take corrective action as needed. The WVDOH inspectors should also monitor this issue.

Table 4.2 shows good confidence in the surface preparation data. The items related to contractor performance, cleaning and sweeping the surface and paving on a dry surface were all rated as good performance.

Table 4.3 shows there was poor to moderate confidence in the hauling observations at the plant. In 2013 there were a maximum of 3 observations for any of the categories. This low number of observations was due to the decisions to focus on the paving operation rather than on plant activities.

The decision to focus on field activities resulted in a good level of confidence for all the placement items shown in Table 4.4. Contractor performance items rated as poor are:

- Tack coat uniformity

- Use of screed vibrator

- $\quad$ Truck to paver interface

- Breaking the load prior to discharging the mix into the paver

- Cross-slope check

- $\quad$ Truck bed cleaning

Each of these, other than the cross slope check, are generally acknowledged in the paving industry as being common problems that need to be resolved with better training of crews and supervisors.

The issue of the cross-slope check may be an artifact of the way the observations were performed. As the co-op was observing the paving process, they were to record when they saw a crew member check the cross-slope. In the 31 observations of this item, the co-ops did not record observing the contractor check the cross-slope even once. Generally cross-sloped is checked at the beginning of the project and it could simply be a case that the co-ops were not present when the check was performed. 
Table 4-5 shows high confidence in the compaction observations and good performance by the contractor. The only area showing poor contractor performance was transverse joint compaction. The best practice is to operate the roller transversely across the pavement. Generally this is not done due to site restrictions prohibiting operating the roller in this manner.

Although there will continue to be areas of pavement construction performance that can be researched into the future. The scope of the anticipated work has been accomplished and recommendations for further research are not presented. 


\section{REFERENCES}

American Association of State Highway and Transportation Officials (AASHTO), Segregation: Causes and cures for hot mix asphalt, Washington, D.C., 1997

Asphalt Institute, The Asphalt Handbook, MS-4, $7^{\text {th }}$ edition, 2010.

BOMAG GmbH, Basic principles of asphalt compaction, Hellerwald, D-56154 Boppard, 2009. http://www.bomag.com/world/media/pdf/PRE109016_0901.pdf

Brock J. D., J.G. May, and G.Renegar, Segregation: causes and cures, Technical Paper T-117 ASTEC, Undated.

Colorado Asphalt Pavement Association, Guide contract documents and specifications for hot mix asphalt construction on Colorado pavements, 2005.

Congress of the United States, Using Public-Private Partnerships to Carry Out Highway Projects, Congressional Budget Office, January 2012.

Direct Industry, the online Industrial Exhibition, http://www.directindustry.com/, Accessed March 2014.

Federal Highway Administration (FHWA), Integrated Materials and Construction practices for concrete pavement: a state of the practice manual, FHWA-HIF-07-004, 2006.

Federal Highway Administration (FHWA), Safety Edge Webpage, http://www.fhwa.dot.gov/everydaycounts/technology/safetyedge/intro.cfm, Accessed March 2014

Foster M., Keeping stockpiles in spec, Aggregates Manager, AL., 2011. http://www.aggman.com/files/2011/08/OpsIll_AGRM0411-td.pdf

GEOENGINEERS, Accessed March 2014, http://www.geoengineers.com/

Georgia Department of Transportation (GDOT), Study guide for aggregate certification, Atlanta, Georgia, 2012.

http://www.dot.ga.gov/doingbusiness/trainingresources/technician/Documents/StudyGuid e9_22_04.pdf

George H., Simmons, Jr., Stockpiles, Technical paper T-129, INTI, Undated. http://www.inti.gob.ar/cirsoc/pdf/tecnologia_hormigon/T-129_Stockpiles.pdf

Graham J.L., Richard K.R., O’Laughlin M.K., and Harwood D.W., Safety Evaluation of the Safety Edge Treatment, Report Number FHWA-HRT-11-024, 2011 
Heatech Inc., Heating and Storing Asphalt at HMA Plants, Technical Paper 140, 2011. http://www.heatec.com/literature/images/T-140.pdf

National Asphalt Pavement Association (NAPA). Balancing Production Rates in Hot Mix Asphalt Operations, Lanham, MD 1996.

National Asphalt Pavement Association (NAPA), Segregation cause and cures for hot mix asphalt, Publication QIP-110, Lanham, MD, 1997.

Pavement Interactive, Accessed March 2014, www.pavementinteractive.org

Quality in California web site, Accessed March 2014, http://www.qualityincalifornia.com

Roberts, F.L., Kandhal, P.S., Brown, E.R., Lee, D.Y., and Kennedy, T.W. Hot Mix Asphalt Materials, Mixture Design, and Construction, National Asphalt Pavement Association Research and Education Foundation, Lanham, MD, 1996.

Russel W., Pavement Design Guide, Texas Department of transportation, 2011. http://onlinemanuals.txdot.gov/txdotmanuals/pdm/placement.htm\#i1009927

Skinner T., Best Practices Quality Asphalt Placement, Short Course in Asphalt Paving \& Construction, BK/IR Road Institute, 2005.

Sunkenberg J., Paver and Screed Operation, Volvo Construction Equipment, April 2012.

Tracey Road Equipments, NY, Accessed March 2014, http://www.traceyroad.com

US Army Corps of Engineers, Hot Mix Asphalt Paving Handbook, 2000.

Volvo Construction Equipments web site, Accessed March 2014, http://www.volvoce.com

Webb Z. L., Seal Coat and Surface Treatment Manual, Texas Department of transportation, 2010, http://onlinemanuals.txdot.gov/txdotmanuals/scm/asphalt_distributor.htm

West Virginia Department of Transportation web site, Accessed March 2014, http://www.transportation.wv.gov

West Virginia Division of Highways, Construction Manual, Charleston, WV, 2002.

West Virginia Division of Highways, Standard Specifications Roads and Bridges, Charleston, WV, 2010.

West Virginia Division of Highways, Field Technician Training Manual. Charleston, WV, 2013. West Virginia Division of Highways, Asphalt Plant Technician Training Manual. Charleston, WV, 2013.

Williams R.C., Duncan G. R. White T.D. Sources, Measurements, and Effects of Segregated Hot Mix Asphalt Pavement. Purdue University, 1996. 


\section{APPENDIX A}

ASPHALT CONSTRUCTION MONITORING FORM 


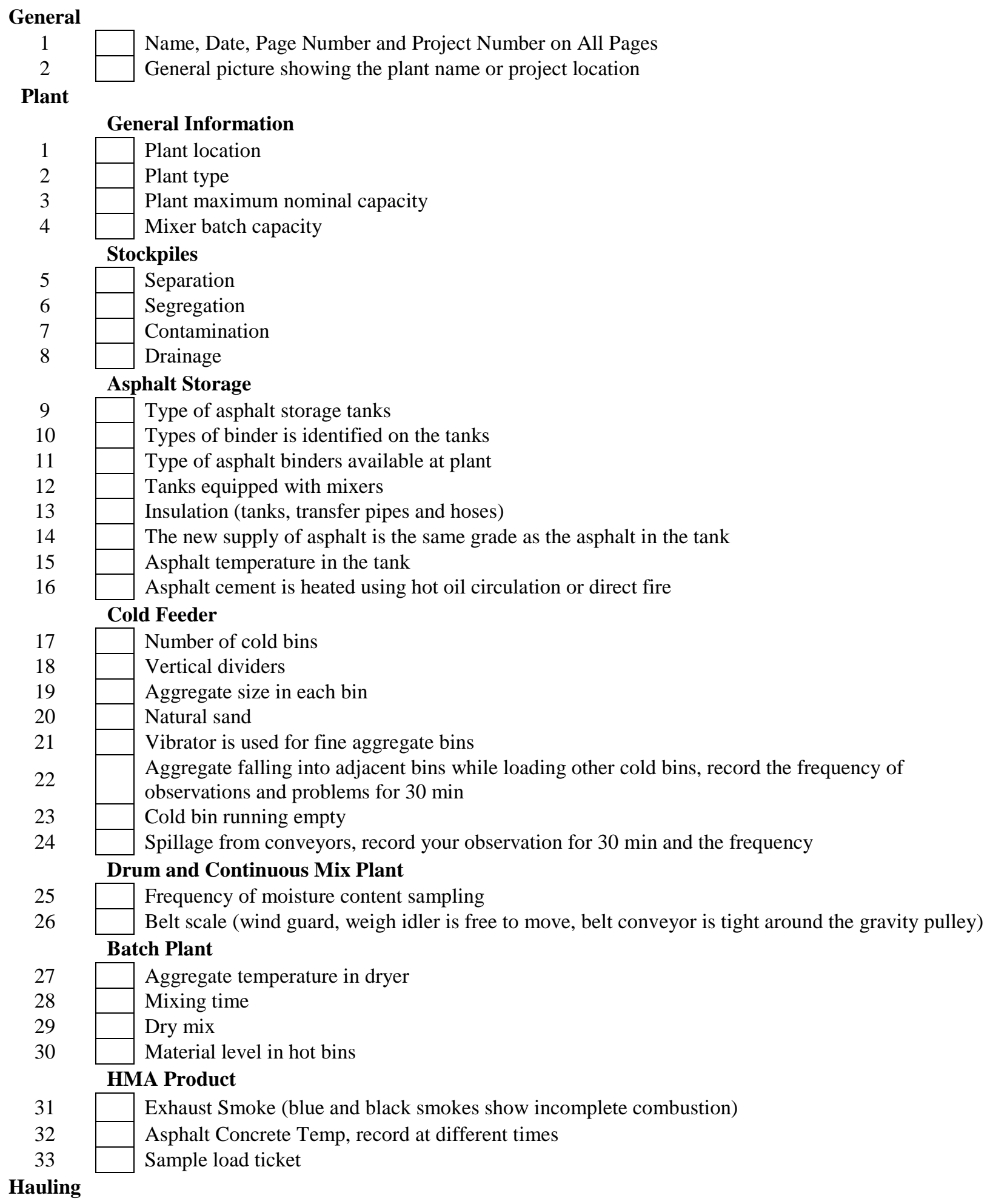

Hauling

Number of cold bins

Vertical dividers

Aggregate size in each bin

Natural sand

Vibrator is used for fine aggregate bins

Aggregate falling into adjacent bins while loading other cold bins, record the frequency of observations and problems for $30 \mathrm{~min}$

Cold bin running empty

Spillage from conveyors, record your observation for $30 \mathrm{~min}$ and the frequency

Drum and Continuous Mix Plant

Frequency of moisture content sampling

Belt scale (wind guard, weigh idler is free to move, belt conveyor is tight around the gravity pulley)

Batch Plant

Aggregate temperature in dryer

Mixing time

Dry mix

Material level in hot bins

\section{HMA Product}

Exhaust Smoke (blue and black smokes show incomplete combustion)

Asphalt Concrete Temp, record at different times

Sample load ticket 


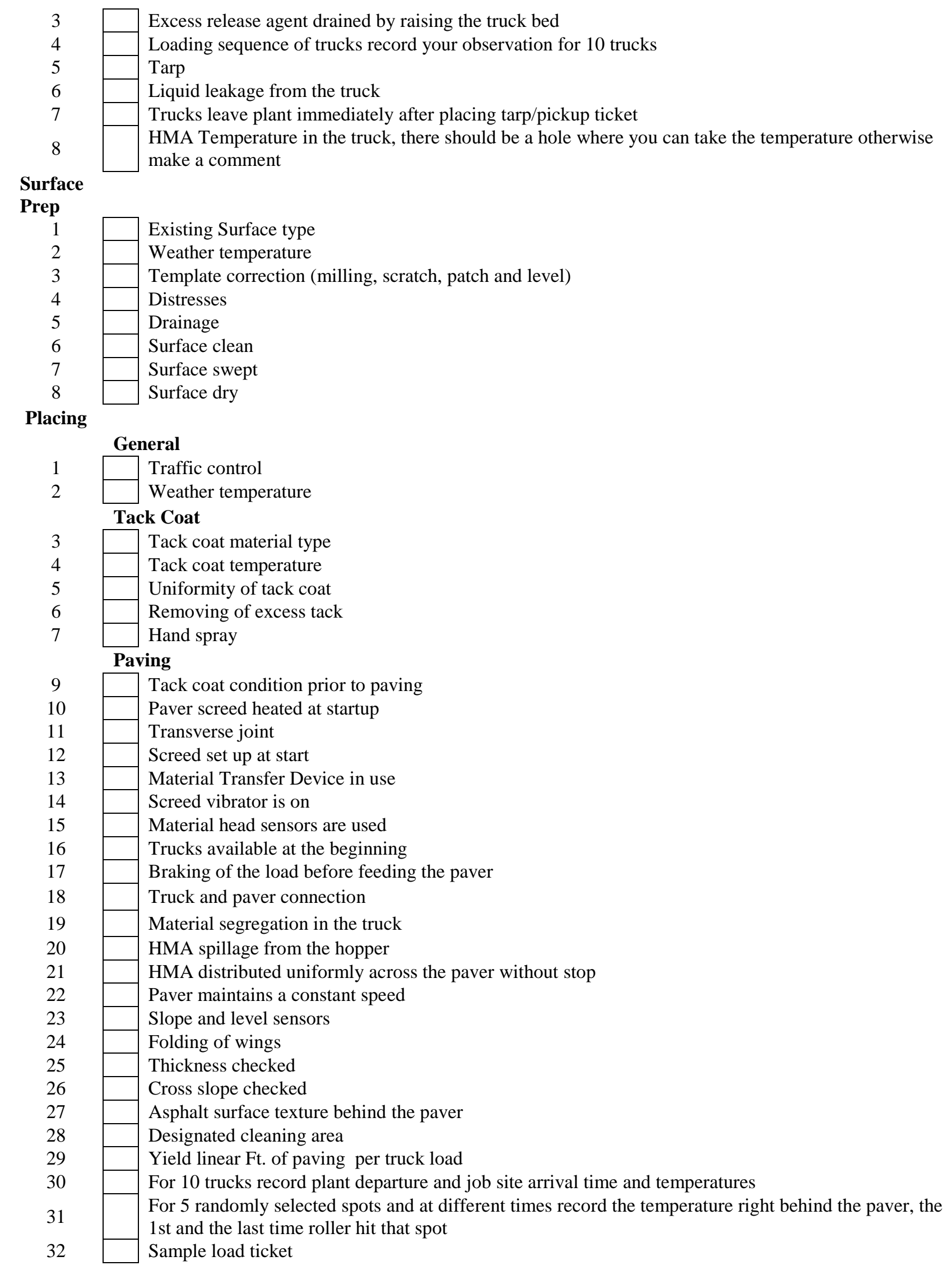




\begin{tabular}{l|l|l}
\multicolumn{3}{l|}{ Joint } \\
33 & & Transverse joint \\
34 & & Longitudinal joint \\
\cline { 2 - 2 } 35 & & Luting \\
36 & & Overlap \\
37 & & Vertical faces are tacked \\
& & Joint faces are intact
\end{tabular}

Compaction

1

Type and number of rollers

Rollers check

$2 \square$ liquid leakage

$3 \quad$ Drum's nozzles

$4 \quad \square$ Scrapers

Rolling

\begin{tabular}{l|l|l}
5 & & Rolling pattern \\
6 & & Verify the roller pattern at three different times \\
7 & & Roller drive drum toward the paver \\
8 & & Roller stopping on hot mat \\
9 & & Roller drums kept moist \\
10 & & Visible defects at the end of compaction \\
\cline { 2 - 3 } & Joints
\end{tabular}

$11 \square$ Transverse joint compacted perpendicular to the paving direction

$12 \quad$ Longitudinal joint compaction 
APPENDIX B

MICROSOFT ACCESS 


\section{ACCESS FILES}

\section{TABLES}

Figure B-1, shows the "access objects" pane on the left side which provides quick access to the tables, quarries and forms.

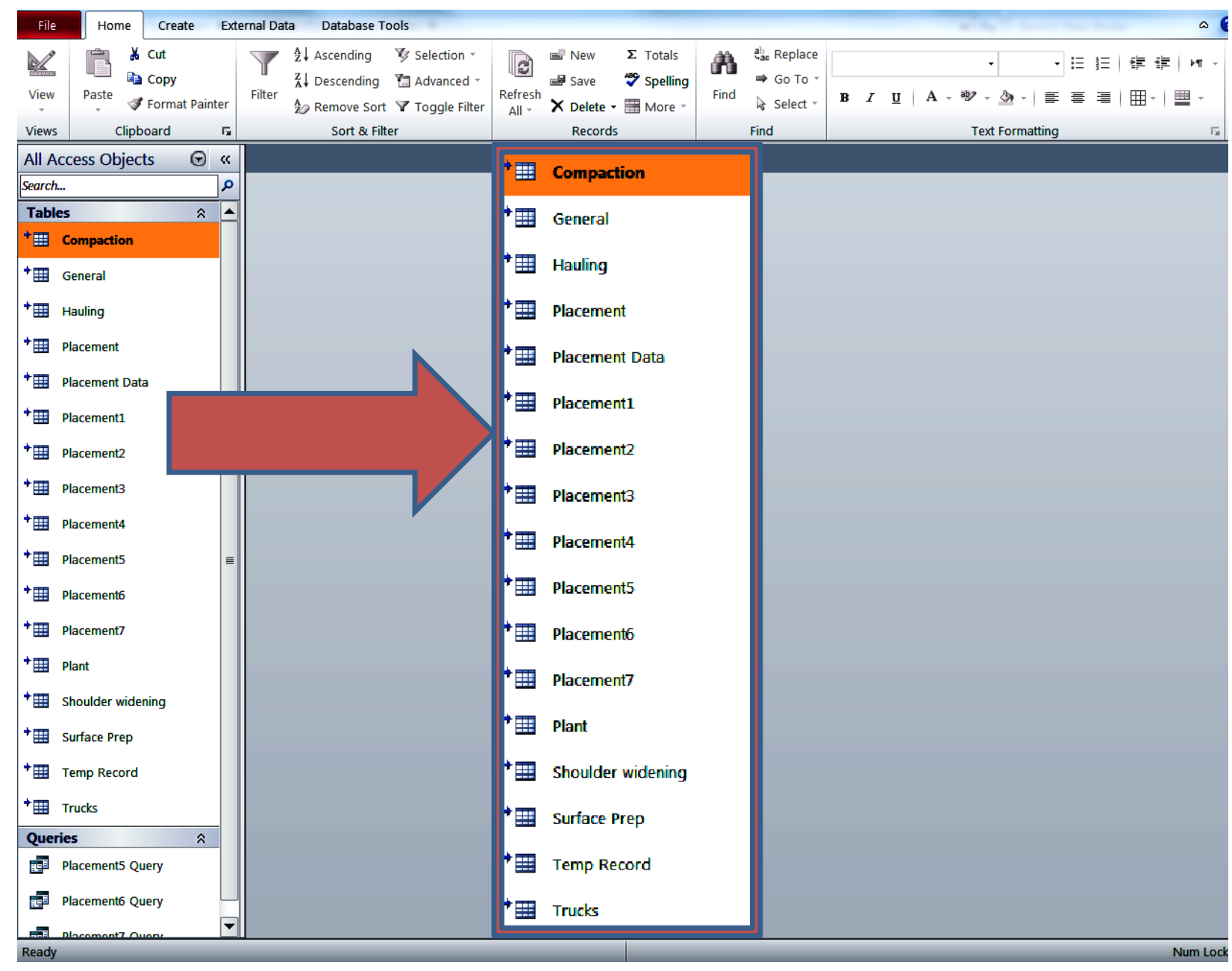

\section{Figure B - 1“Access" Preview}

Tables are in fact the original place where the data are saved. In this project there are 17 tables.

Figure B-2 shows the "General" table. 


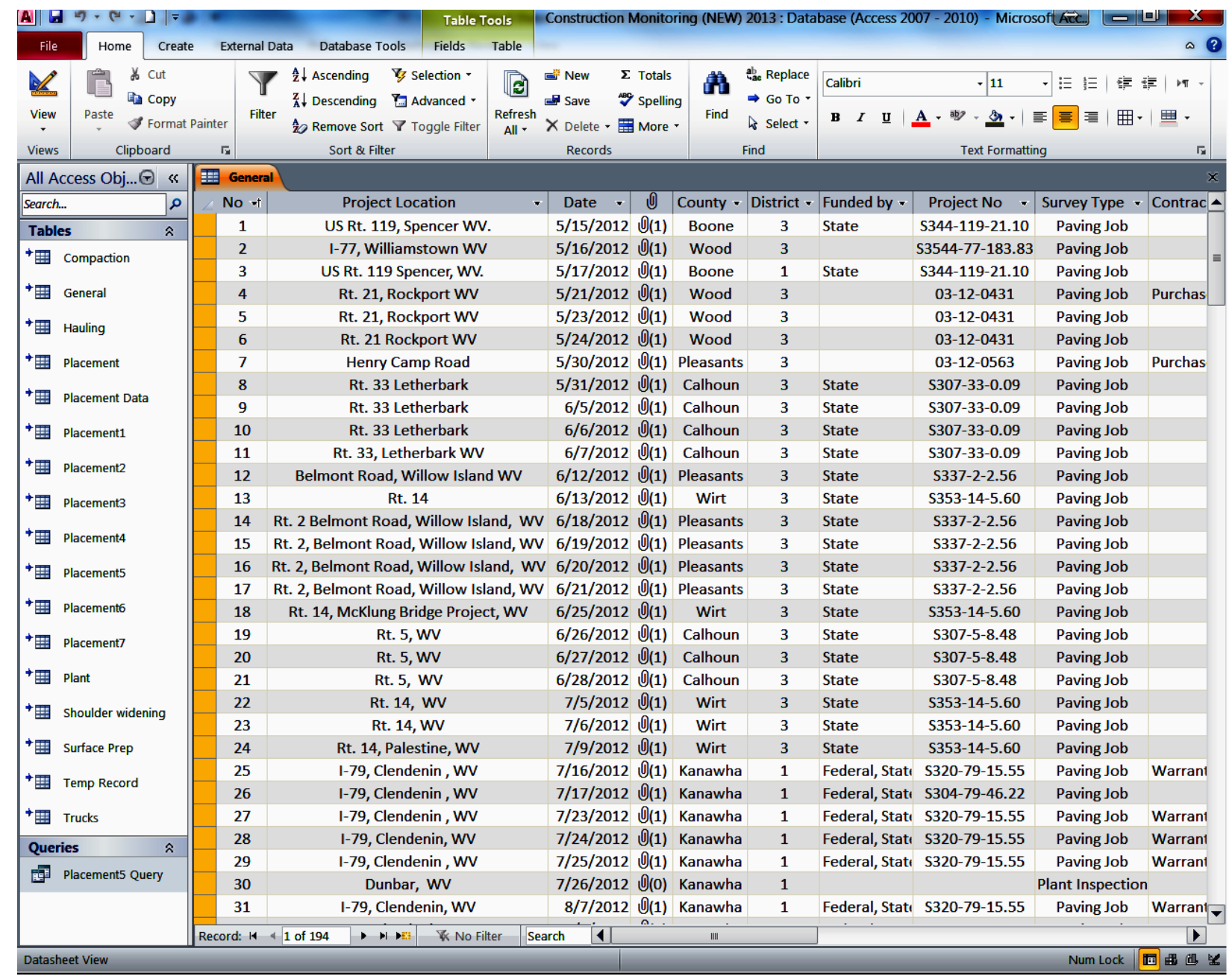

Figure B - 2 “General" Table Preview

\section{FORMS}

In fact, forms are the tables' interfaces which provide a more user-friendly environment to deal with the entries.

For each form in the database there is a table where the data are stored originally.

To view the files attached in the forms, users should take the following steps:

1- Move the pointer over the icon of the attached file till a small control pane appears on the top of the icon (the icon usually gives a preview of the attached file). See Figure B-3 for further illustration.

2- Click the paper clip icon. 
3- From the attachment window select your file and click "open”. See Figure B-4.

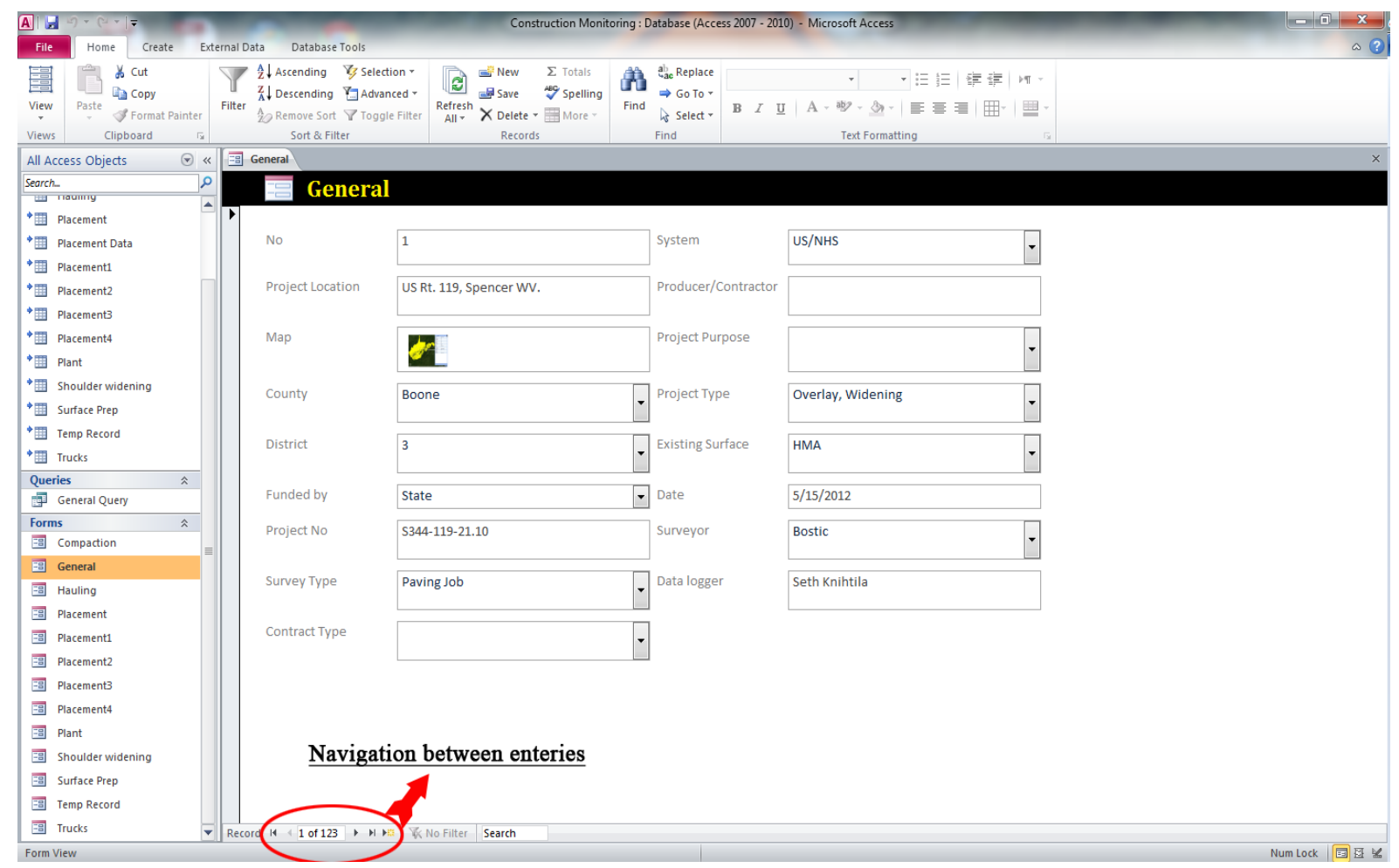

Figure B - 3"General" form preview 


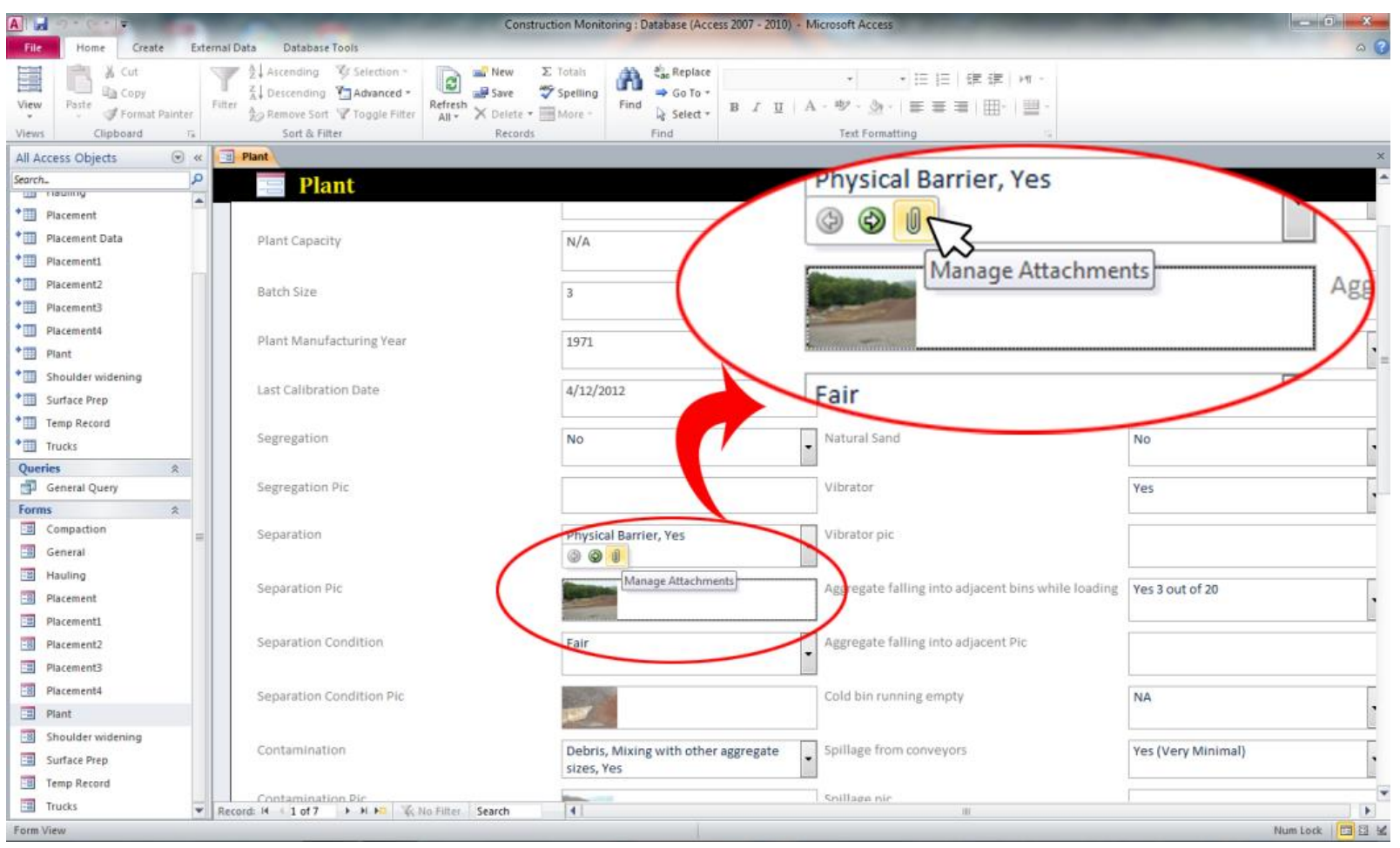

Figure B - 4 Opening the attached files

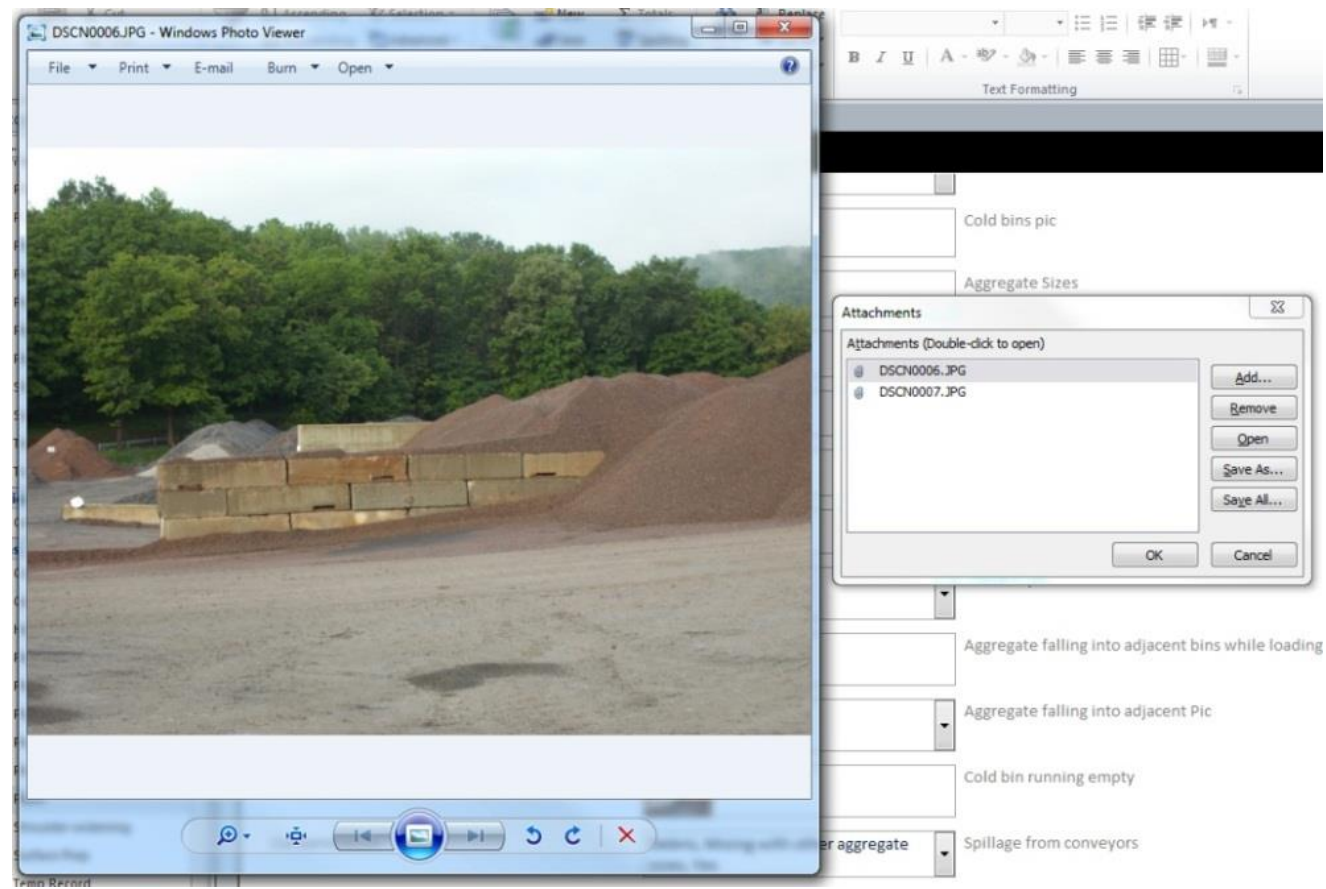

Figure B - 5 viewing the attached file 


\section{QUERIES}

Take the following steps to build queries inside the access database:

1. From the create tab click on the "Query Wizard", see Figure B-6.

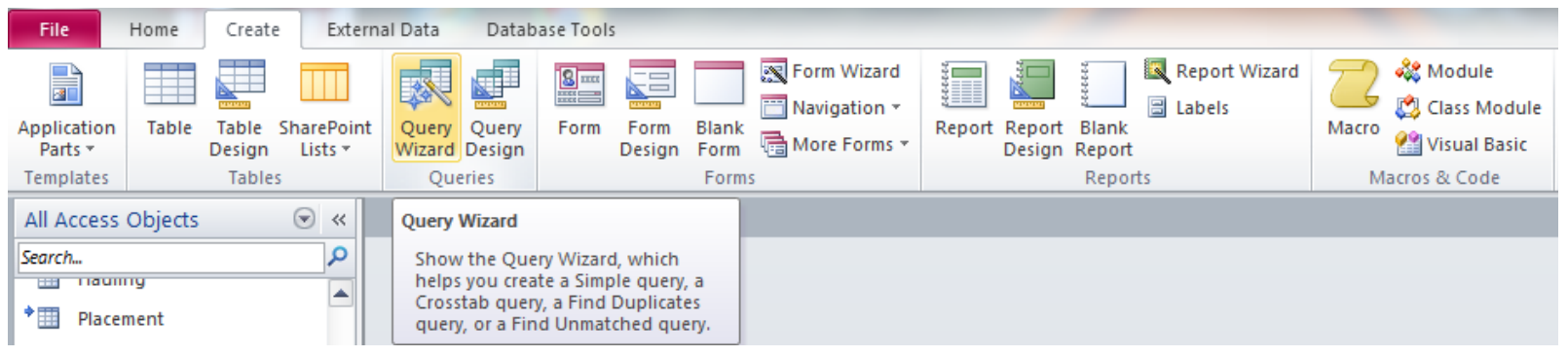

\section{Figure B - 6 Query Wizard}

2. Choose the "Simple Query Wizard" from the "New Query" window and click "OK". See Figure B-7.

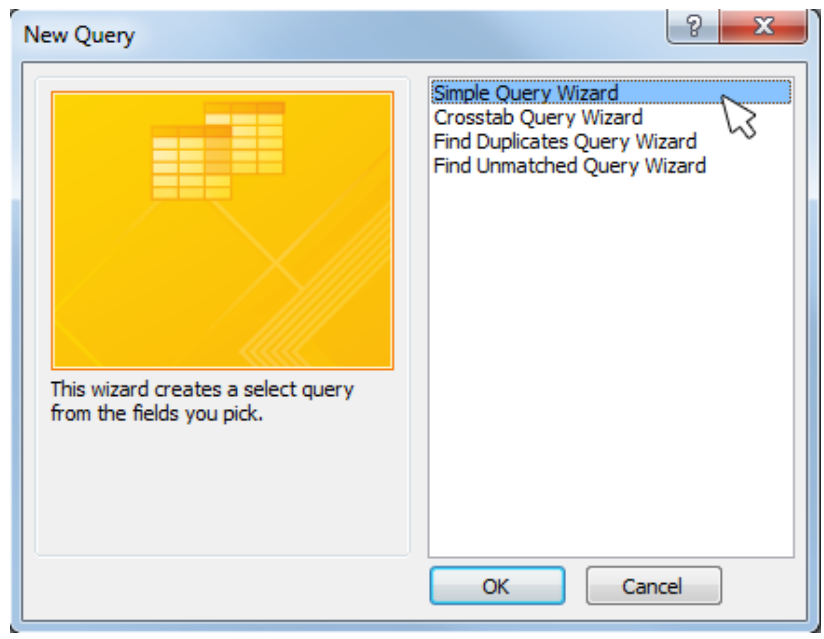

Figure B -7 Simple Query

3. In the new window, from the drop down menu for tables/queries pick the table which your parameter of interest is in. From the available fields select those which the query should be build based on. 
Example: For the available database, make a report which shows the project types and the contractors that has been evaluated in each district.

As illustrated in Figure B-8, the "General" is selected from the drop down menu. Selected fields include "No", "District", "Contractor", "Project Type”. Figure B-9, show the built query. It is also possible to either sort or filter the results based on the any of the fields. For instance Figure B-10 shows the sorting and filtering based on the district No. within the query.

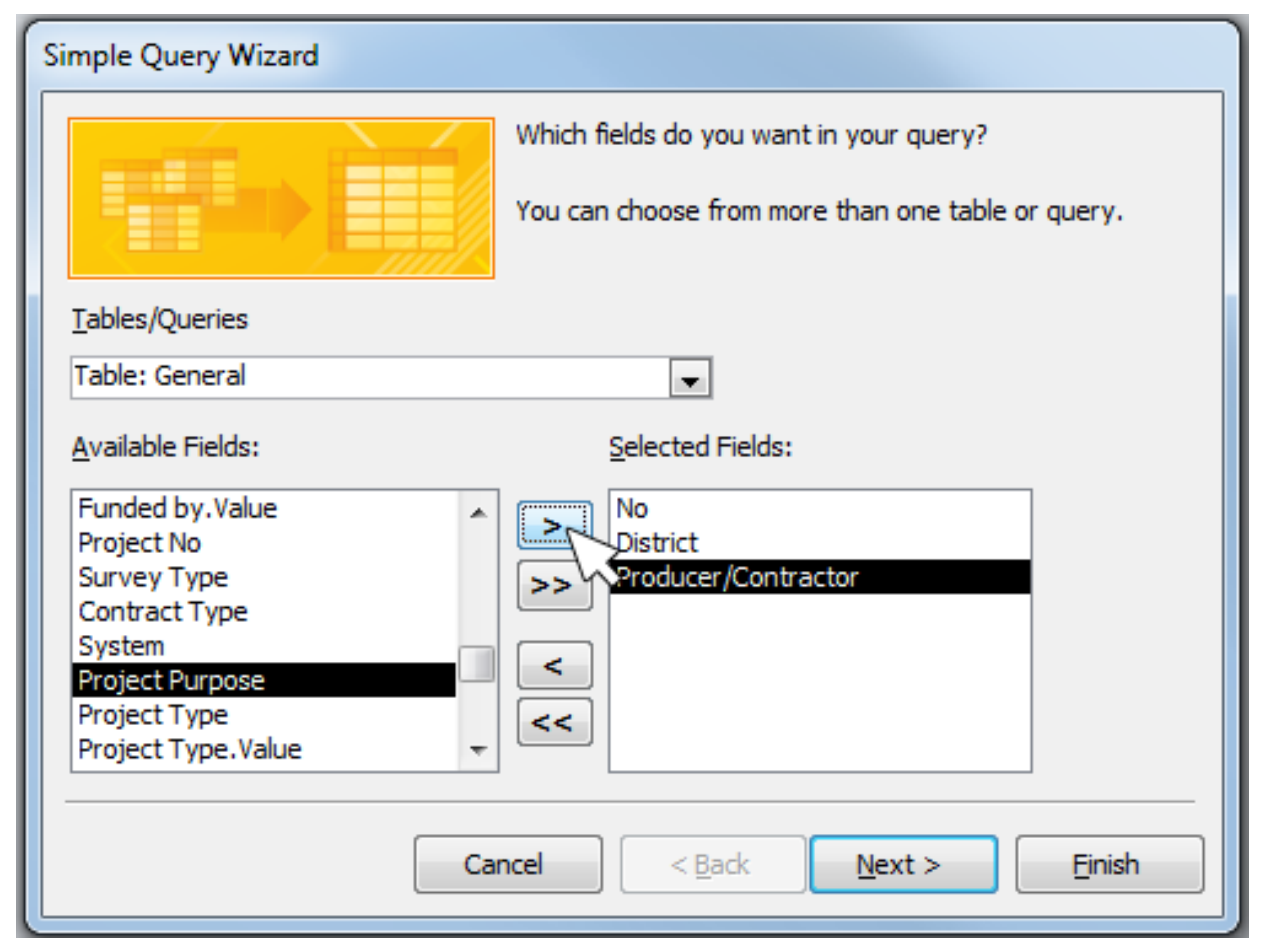

Figure B - 8 choosing fields to make the query 


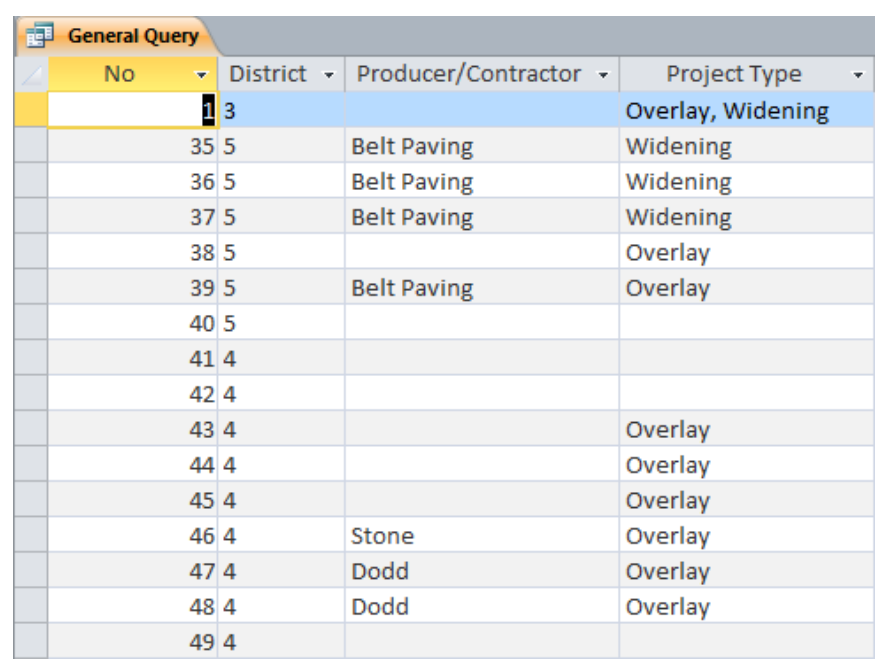

Figure B - 9 viewing the query

Now that the query is ready, if statistical analysis is required, the query should be exported to Microsoft Excel. To export the query, select it and then from the "Export" section in the "External Data" tab, click the "Excel" icon. The Microsoft Access will ask for the location to save the excel file. Browse to the desired location on the hard drive and click "Finish".
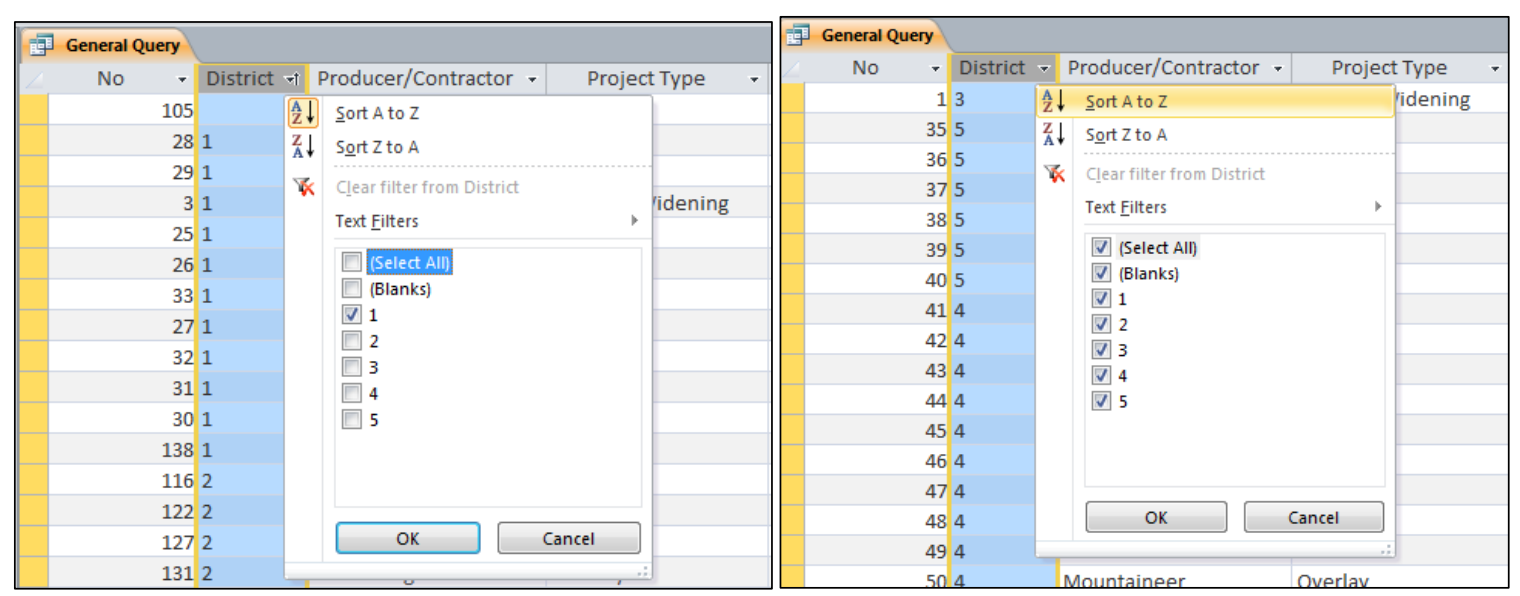

Figure B - 10 sorting and filtering within the queries 


\section{REPORTS}

To produce reports in a professional format, go to the "Create" tab and click "Report".

Figure B-11, shows the report produced for the query example.

\begin{tabular}{|c|c|c|c|c|}
\hline$\square$ & ral 0 & ery & \multicolumn{2}{|c|}{$\begin{array}{r}\text { Friday, January 18, } 2013 \\
10: 54: 25 \text { AM }\end{array}$} \\
\hline No & District & Producer/Contractor & Project Type & Surveyor \\
\hline 105 & & New Enterprise & & Shields \\
\hline 28 & 1 & WV Paving & Overlay & Bostic \\
\hline 29 & 1 & WV Paving & Overlay & Bostic \\
\hline 3 & 1 & & Overlay, Widening & Bostic \\
\hline 25 & 1 & WV Paving & Overlay & Bostic \\
\hline 26 & 1 & WV Paving & & Bostic \\
\hline 33 & 1 & WV Paving & Overlay & Bostic \\
\hline 27 & 1 & WV Paving & Overlay & Bostic \\
\hline 32 & 1 & WV Paving & Overlay & Bostic \\
\hline 31 & 1 & WV Paving & Overlay & Bostic \\
\hline 30 & 1 & Dunbar Plant Visit & & Bostic \\
\hline 138 & 1 & & & Hays \\
\hline
\end{tabular}

Figure B - 11 report example 
APPENDIX C

SUMMARY OF THE BEST HMA CONSTRUCTION PRACTICES 


\section{HMA PLANT OPERATION}

- Place stockpiles on a clean, dry, firm and stable drainable base, gently sloped surface downward from northwest face.

- Avoid stockpiles contamination; apply physical barrier or adequate distance between stockpiles.

- Avoid stockpile segregation; do not raise stockpiles elevation too much high because larger aggregates tend to roll down from higher piles. Aggregate should not being pushed or dumped over the side of stockpiles.

- The front end loader should remove aggregates in a direction perpendicular to the flow of the aggregate into stockpile.

- If segregation happened in stockpiles, the material should be pre-blended before fed into cold- feed bins.

- Determine moisture content of each stockpile before fed into cold-feed bins.

- Use vertical divider between bins

- Avoid running cold bins empty

- Prevent spillage from conveyors

- Calibrate cold feed system;

- Use vertical tank

- Asphalt temperature in the storage tank should be between $150^{\circ} \mathrm{C}\left(300^{\circ} \mathrm{F}\right)$ and $180^{\circ} \mathrm{C}$ $\left(350^{\circ} \mathrm{F}\right)$

- Appropriate Insulation of tanks, transfer pipes and hoses

- Control moisture content of discharged aggregate from dryer in batch plant (less than 0.5 percent)

- Minimize aggregate dry time in the pugmill for batch plant.

- Control the duration of blending mix (wet-mix cycle) together

- Control the total mix cycle time from beginning to end

- Control the discharged mix by sampling to ensure that mix components are fully blended

\section{HAULING}

- Truck bed clean before loading

- Proper truck side and bed insulation 
- Apply approved release agents

- $\quad$ Truck should mechanically sound with no liquid leakage

- Apply the correct loading sequences (front, back, middle in 3 equal loads)

- Appropriate tarp

- Minimize truck delay at plant after loading to allow consistent delivery to the site

- Apply load break before unloading mix into hopper ; before the truck tailgate is opened the truck bed should be lifted slightly while backing up to paver. The truck tailgate is opened whenever the mix in the bed moves against the tailgate and approach to the hopper.

\section{SURFACE PREPARATION}

- Template correction if needed including, milling, scratch, or patch and level

- $\quad$ Dry surface prior to paving start

- Clean and sweep of the existing pavement surface immediately prior to tack coat

\section{TACK COAT}

- Uniform tack coat placement over the entire surface

- Hot sand should be placed on areas with excess tack coat.

- Tack coat break before laying asphalt

\section{PLACEMENT}

- Appropriate traffic control

- $\quad$ Screed set up

- Screed heated up to the paving temperature

- Adjust the auger to avoid mix segregation

- Appropriate truck and paver connection (truck must avoid bump the paver, paver should not stop for truck to approach, truck and paver should move together)

- Continuous delivery of material into the hopper

- Clean the truck bed in the designated area, not in front of paver

- Material Transfer Vehicle (MTV) is recommended

- Prevent hopper overflow 
- Remove spillage material from the surface

- Maintain a constant head across screed so the forces on the screed do not cause any unwanted change in the mat thickness.

- Avoid folding the hopper wings; the operator should never fold the wings to dispose of the cool material into hopper. However, the paver wings can also be folded after each load to stop cold mat buildup in the corners of hopper.

- $\quad$ Check the mat thickness frequently

- $\quad$ Check the cross slope on the mat frequently

- Carefully lute the overlay material back to the joint and do only if needed

- To build a longitudinal joint, overlap the previous layer no more than $1 \frac{1}{2}$ in. The thickness of new placed mix should be $1 / 4$ in. per 1 in. layer greater than the compacted mix.

\section{COMPACTION}

- Check roller for mechanic condition, liquid leakage, nozzles, and scrappers

- $\quad$ Keep the roller drums moist

- Obtain required density before the mix cools to a minimum temperature of $175^{\circ} \mathrm{F}\left(80^{\circ} \mathrm{C}\right)$.

- Do the uniform rolling pattern at all points transversely across the lane being paved.

- Do not stop roller on hot mat

- Do not run roller directly on the unsupported edge; hold roller drum 6 inches away from unsupported edge on a first pass. This leaves a narrow strip of uncompacted mat. As a roller reverses direction, this narrow strip is compacted by the roller drum.

- For longitudinal joints compaction, hold roller drum 6 inches away from the joint on the first pass. This results in a thin strip of uncompacted mat. By way of the roller reverse direction, the roller drum should be moved over this left thin strip and overlap 6 inches (150 millimeters) on the cold mat, trapping thin strip under the drum and forcing it into place.

- Transverse joints should be compacted perpendicular to the paving direction if possible. 